\title{
The International Drug Control Conventions
}

Single Convention on Narcotic Drugs of 1961 as amended by the 1972 Protocol

Convention on Psychotropic Substances of 1971

United Nations Convention against Illicit Traffic in Narcotic Drugs and Psychotropic Substances of 1988

with final acts and resolutions

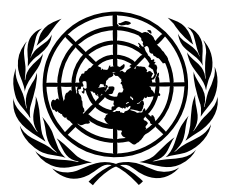



UNITED NATIONS OFFICE ON DRUGS AND CRIME Vienna

\title{
The International Drug Control Conventions
}

\author{
Single Convention on Narcotic Drugs of \\ 1961 as amended by the 1972 Protocol \\ Convention on Psychotropic Substances of 1971 \\ United Nations Convention against Illicit Traffic in \\ Narcotic Drugs and Psychotropic Substances of 1988
}

with final acts and resolutions

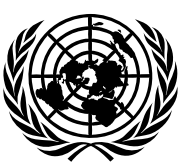

UNITED NATIONS

New York, 2013 
The present publication was prepared by the Secretariat to the Governing Bodies, Division for Treaty Affairs, United Nations Office on Drugs and Crime. It is to be published in the six official languages of the United Nations: Arabic, Chinese, English, French, Russian and Spanish.

(C) United Nations, November 2013. All rights reserved, worldwide.

The designations employed and the presentation of material in this publication do not imply the expression of any opinion whatsoever on the part of the Secretariat of the United Nations concerning the legal status of any country, territory, city or area, or of its authorities, or concerning the delimitation of its frontiers or boundaries.

Publishing production: English, Publishing and Library Section, United Nations Office at Vienna. 


\section{Contents}

Introduction $\ldots \ldots \ldots \ldots \ldots \ldots \ldots \ldots \ldots \ldots \ldots \ldots \ldots \ldots \ldots \ldots \ldots \ldots$

\section{Part One}

Single Convention on Narcotic Drugs of 1961 as amended by

the 1972 Protocol. . . . . . . . . . . . . . . . . . . . . . . . . . . . . . . . . .

\section{Part Two}

Convention on Psychotropic Substances of $1971 \ldots \ldots \ldots \ldots \ldots \ldots \ldots$

\section{Part Three}

United Nations Convention against Illicit Traffic in Narcotic Drugs and Psychotropic Substances of 1988 . . . . . . . . . . . . . . . . . . . . . . . . . 107 



\section{Introduction}

The present publication contains the texts of the three main international drug control conventions: the Single Convention on Narcotic Drugs of 1961 as amended by the 1972 Protocol, ${ }^{1}$ the Convention on Psychotropic Substances of $1971^{2}$ and the United Nations Convention against Illicit Traffic in Narcotic Drugs and Psychotropic Substances of $1988 .^{3}$

The revised schedules of narcotic drugs under international control are issued separately under document symbol ST/CND/1/Add.1.

The revised schedules of psychotropic substances under international control are issued under document symbol ST/CND/1/Add.2.

The revised tables of substances frequently used in the illicit manufacture of narcotic drugs and psychotropic substances under international control are issued under document symbol ST/CND/1/Add.3.

Those addenda will be updated whenever the Commission on Narcotic Drugs takes a decision to amend one of the schedules of narcotic drugs and psychotropic substances under international control or one of the tables of substances frequently used in the illicit manufacture of narcotic drugs and psychotropic substances under international control. Any decision taken by the Commission on Narcotic Drugs with respect to scheduling will also be brought to the attention of Member States, the World Health Organization and the International Narcotics Control Board through a notification by the Secretary-General, and the updated schedules will be posted on the relevant web page of the United Nations Office on Drugs and Crime.

Information on the status of the international drug control conventions, as well as of other multilateral treaties deposited with the Secretary-General, and on their entry into force is available from the following website: http://treaties. un.org/Pages/ParticipationStatus.aspx.

\footnotetext{
${ }^{1}$ United Nations, Treaty Series, vol. 976, No. 14152.

${ }^{2}$ Ibid., vol. 1019, No. 14956.

${ }^{3}$ Ibid., vol. 1582, No. 27627.
} 

Part One

\section{SINGLE CONVENTION ON NARCOTIC DRUGS OF 1961 AS AMENDED BY THE 1972 PROTOCOL}

including Final Acts and Resolutions as agreed by the 1961 United Nations Conference for the Adoption of a Single Convention on Narcotic Drugs and by the 1972 United Nations Conference to consider amendments to the

Single Convention on Narcotic Drugs, 1961, respectively 



\section{Contents}

United Nations Conference for the Adoption of a Single Convention

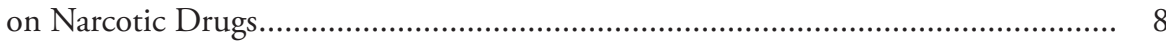

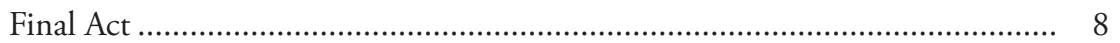

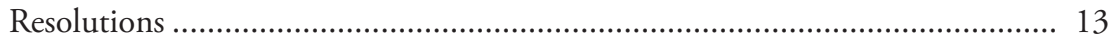

United Nations Conference to consider amendments to the Single Convention on Narcotic Drugs, 1961 ..................................................... 15

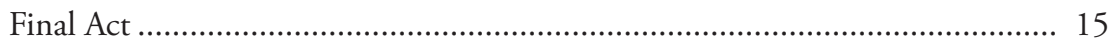

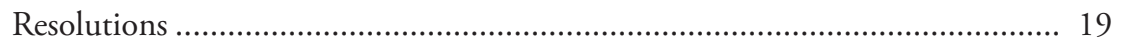

Single Convention on Narcotic Drugs, 1961, as amended by the 1972 Protocol amending the Single Convention on Narcotic Drugs, 1961 ................................. 23

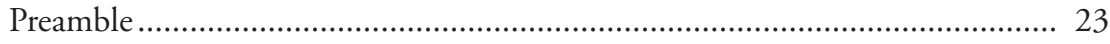

Article 1. Definitions........................................................................... 24

Article 2. Substances under control......................................................... 26

Article 3. Changes in the scope of control ............................................. 28

Article 4. General obligations ............................................................ 30

Article 5. The international control organs .......................................... 30

Article 6. Expenses of the international control organs ............................. 30

Article 7. Review of decisions and recommendations of the Commission .... 31

Article 8. Functions of the Commission ................................................. 31

Article 9. Composition and functions of the Board ................................ 31

Article 10. Terms of office and remuneration of members of the Board ........ 32

Article 11. Rules of procedure of the Board ............................................. 33

Article 12. Administration of the estimate system ...................................... 33 
Article 13. Administration of the statistical returns system

Article 14. Measures by the Board to ensure the execution of provisions of the Convention.

Article 14 bis $\quad$ Technical and financial assistance ....................................... 37

Article 15. Reports of the Board .......................................................... 37

Article 16. Secretariat .......................................................................... 37

Article 17. Special administration ......................................................... 38

Article 18. Information to be furnished by Parties to the Secretary-General... 38

Article 19. Estimates of drug requirements ............................................. 38

Article 20. Statistical returns to be furnished to the Board ........................... 40

Article 21. Limitation of manufacture and importation............................. 41

Article 21 bis. Limitation of production of opium .................................... 42

Article 22. Special provision applicable to cultivation ................................ 43

Article 23. National opium agencies ......................................................... 43

Article 24. Limitation on production of opium for international trade ......... 44

Article 25. Control of poppy straw ........................................................... 46

Article 26. The coca bush and coca leaves ................................................ 47

Article 27. Additional provisions relating to coca leaves............................. 47

Article 28. Control of cannabis................................................................. 47

Article 29. Manufacture ......................................................................... 48

Article 30. Trade and distribution.......................................................... 48

Article 31. Special provisions relating to international trade......................... 50

Article 32. Special provisions concerning the carriage of drugs in first-aid kits of ships or aircraft engaged in international traffic ............... 52

Article 33. Possession of drugs ............................................................... 53 
Article 34. Measures of supervision and inspection................................... 53

Article 35. Action against the illicit traffic................................................. 54

Article 36. Penal provisions ..................................................................... 54

Article 37. Seizure and confiscation ........................................................ 56

Article 38. Measures against the abuse of drugs ........................................ 57

Article 38 bis. Agreements on regional centres........................................ 57

Article 39. Application of stricter national control measures than those required by this Convention..................................................... 57

Article 40. Languages of the Convention and procedure for signature, ratification and accession...................................................... 58

Article 41. Entry into force................................................................ 58

Article 42. Territorial application............................................................. 59

Article 43. Territories for the purposes of articles 19, 20, 21 and $31 \ldots \ldots \ldots . . . .59$

Article 44. Termination of previous international treaties ........................... 59

Article 45. Transitional provisions ............................................................. 61

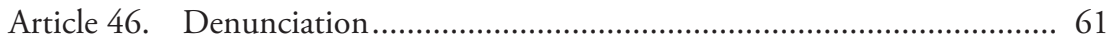

Article 47. Amendments......................................................................... 62

Article 48. Disputes............................................................................... 62

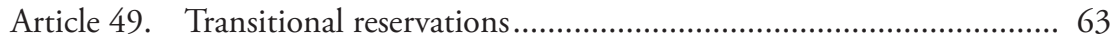

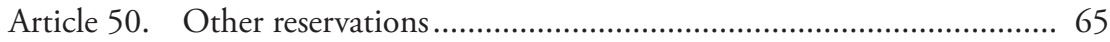

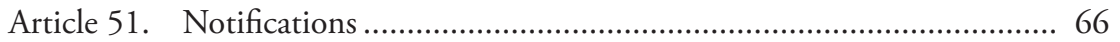




\section{Final Act of the United Nations Conference for the Adoption of a Single Convention on Narcotic Drugs}

1. The Economic and Social Council of the United Nations, by resolution $689 \mathrm{~J}$ (XXVI) of 28 July 1958, decided to convene in accordance with Article 62, paragraph 4, of the Charter of the United Nations, and with the provisions of General Assembly resolution 366 (IV) of 3 December 1949, a plenipotentiary conference for the adoption of a single convention on narcotic drugs to replace by a single instrument the existing multilateral treaties in the field, to reduce the number of international treaty organs exclusively concerned with control of narcotic drugs, and to make provision for the control of the production of raw materials of narcotic drugs.

2. The United Nations Conference for the Adoption of a Single Convention on Narcotic Drugs met at United Nations Headquarters from 24 January to 25 March 1961.

3. The following seventy-three States were represented by representatives at the Conference:

\begin{tabular}{lll} 
Afghanistan & Chile & Ghana \\
Albania & China & Greece \\
Argentina & Congo (Léopoldville) & Guatemala \\
Australia & Costa Rica & Haiti \\
Bolivia & Czechoslovakia & Holy See \\
Brazil & Dahomey & Hungary \\
Bulgaria & Denmark & India \\
Burma & Dominican Republic & Indonesia \\
Byelorussian Soviet & El Salvador & Iran \\
\multicolumn{1}{c}{ Socialist Republic } & Finland & Iraq \\
Cambodia & France & Israel \\
Canada & Germany, Federal & Italy \\
Chad & Republic of & Japan
\end{tabular}




$\begin{array}{llc}\text { Jordan } & \text { Panama } & \text { Ukrainian Soviet } \\ \text { Korea, Republic of } & \text { Paraguay } & \text { Socialist Republic } \\ \text { Lebanon } & \text { Peru } & \text { Union of Soviet } \\ \text { Liberia } & \text { Philippines } & \text { Socialist Republics } \\ \text { Madagascar } & \text { Poland } & \text { United Arab Republic } \\ \text { Mexico } & \text { Portugal } & \text { United Kingdom of } \\ \text { Monaco } & \text { Romania } & \text { Great Britain and } \\ \text { Morocco } & \text { Senegal } & \text { Northern Ireland } \\ \text { Netherlands } & \text { Spain } & \text { United States of } \\ \text { New Zealand } & \text { Sweden } & \text { America } \\ \text { Nicaragua } & \text { Switzerland } & \text { Uruguay } \\ \text { Nigeria } & \text { Thailand } & \text { Venezuela } \\ \text { Norway } & \text { Tunisia } & \text { Yugoslavia } \\ \text { Pakistan } & \text { Turkey } & \end{array}$

4. The following State was represented by an observer at the Conference: Ceylon.

5. The following specialized agency was represented at the Conference:

Food and Agriculture Organization of the United Nations;

International Civil Aviation Organization;

International Labour Organisation;

World Health Organization.

6. The following international bodies were represented at the Conference: Permanent Central Opium Board;

Drug Supervisory Body.

7. The following non-governmental organizations were also represented at the Conference:

International Conference of Catholic Charities;

International Criminal Police Organization;

International Federation of Women Lawyers. 
8. General Safwat, Director of the Permanent Anti-Narcotics Bureau of the League of Arab States, at the invitation of the Conference, also attended in a personal capacity.

9. In accordance with the resolution of the Economic and Social Council referred to in paragraph 1 and with the rules of procedure adopted by the Conference, the observers and the representatives of the above-mentioned organizations and bodies participated in the work of the Conference without the right to vote.

10. The Conference elected Mr. Carl Schurmann (Netherlands) as President, and as Vice-Presidents the representatives of the following States:

$\begin{array}{llc}\text { Afghanistan } & \text { Japan } & \text { Union of Soviet } \\ \text { Brazil } & \text { Mexico } & \text { Socialist Republics } \\ \text { Dahomey } & \text { Pakistan } & \text { United Arab Republic } \\ \text { France } & \text { Peru } & \text { United Kingdom of } \\ \text { Hungary } & \text { Switzerland } & \text { Great Britain and } \\ \text { India } & \text { Thailand } & \text { Northern Ireland } \\ \text { Iran } & \text { Turkey } & \text { United States of }\end{array}$

11. The Executive Secretary of the Conference was Mr. G. E. Yates, and the Deputy Executive Secretary was Mr. Adolf Lande.

12. The Conference had before it, in accordance with the resolution of the Economic and Social Council, the third draft of a single convention on narcotic drugs prepared by the Commission on Narcotic Drugs of the Council and a compilation of the comments thereon; it also had before it other documentation prepared by the Secretariat.

13. The Conference set up the following committees:

\section{General Committee}

Chairman: The President of the Conference

Ad Hoc Committee on articles 2 and 3 of the Third Draft (Scope of the Convention and Method of Bringing Additional Substances under Control)

Chairman: Mr. A. Tabibi (Afghanistan) 
Ad Hoc Committee on articles 25, 30 and 40-43 (National Control in General)

Chairman: Mr. B. Banerji (India)

Ad Hoc Committee on articles 31-34 (National Control of Opium Poppy and Poppy Straw)

Chairman: Mr. L. Ignacio-Pinto (Dahomey)

Vice-Chairman: Mr. J. Koch (Denmark)

Ad Hoc Committee on articles 35-38 (National Control of Coca Leaf)

Chairman: Mr. K. Chikaraishi (Japan)

Ad Hoc Committee on article 39 (National Control of Cannabis)

Chairman: Mr. B. Grinberg (Bulgaria)

Ad Hoc Committee on articles 26, 27-29, 20-21, 4 (Information to be furnished by Governments; the system of estimates and statistics; obligations of Governments in general)

Chairman: Mr. E. Rodriguez Fabregat (Uruguay)

Vice-Chairman: Mr. J. Bertschinger (Switzerland)

Ad Hoc Committee on article 22 (Measures exercisable by the Board in case of noncompliance)

Chairman: Mr. A. Gurinovich (Byelorussian SSR)

Ad Hoc Committee on articles 5-11, 13-19, 23 (Constitution, Functions and Secretariat of International Organs)

Chairman: Mr. H. Blomstedt (Finland)

Ad Hoc Committee on articles 44-46 (Direct Measures against the Illicit Traffic)

Chairman: Mr. A. Bittencourt (Brazil)

\section{Technical Committee}

Chairman: Mr. A. Johnson (Australia)

Vice-Chairman: Mr. A. Ismael (United Arab Republic) 


\section{Drafting Committee}

Chairman: Mr. R. Curran (Canada)

Vice-Chairman: Mr. D. Nikolić (Yugoslavia)

\section{Credentials Committee}

Chairman: Mr. G. Ortiz (Costa Rica)

14. As the result of its deliberations, as recorded in the summary records of the Plenary and the summary records and reports of the committees, the Conference adopted ${ }^{1}$ and opened for signature the Single Convention on Narcotic Drugs, 1961. In addition the Conference adopted the five resolutions annexed to this Final Act.

IN WITNESS WHEREOF the representatives have signed this Final Act.

DONE at New York, this thirtieth day of March one thousand nine hundred and sixty-one, in a single copy in the Chinese, English, French, Russian and Spanish languages, each text being equally authentic. The original texts shall be deposited with the Secretary-General of the United Nations.

${ }^{1}$ The Conference took note that the Convention was approved without prejudice to decisions or declarations in any relevant General Assembly resolution. 


\title{
Resolutions adopted by the United Nations Conference for the Adoption of a Single Convention on Narcotic Drugs
}

\author{
Resolution I \\ Technical assistance on narcotic drugs
}

The Conference,

Welcoming the establishment by General Assembly resolution 1395 (XIV) of special arrangements for technical assistance in the field of narcotics control,

Noting that the United Nations and the specialized agencies concerned have already provided a limited amount of assistance under the Expanded Programme of Technical Assistance and in their regular programmes,

Welcoming also the co-operation of the International Criminal Police Organization in the execution of technical assistance projects,

Expresses the hope that adequate resources will be made available to provide assistance in the fight against the illicit traffic, to those countries which desire and request it, particularly in the form of expert advisers and of training, including training courses for national officials.

\section{Resolution II \\ Treatment of drug addicts}

The Conference,

Recalling the provisions of article 38 of the Convention concerning the treatment and rehabilitation of drug addicts,

1. Declares that one of the most effective methods of treatment for addiction is treatment in a hospital institution having a drug free atmosphere;

2. Urges Parties having a serious drug addiction problem, and the economic means to do so, to provide such facilities. 


\section{Resolution III \\ Illicit traffickers}

\section{The Conference,}

1. Calls attention to the importance of the technical records on international traffickers kept at present by the International Criminal Police Organization;

2. Recommends that these records be completed as far as possible by all parties and be widely used for the circulation of description of the traffickers by that Organization.

\section{Resolution IV \\ Membership of the Commission on Narcotic Drugs}

\section{The Conference,}

Invites the Economic and Social Council to examine at its thirty-second session the question of an increase in the membership of the Commission on Narcotic Drugs, in the light of the terms of this Convention and of the views expressed on this question at this Conference.

\section{Resolution $V$ \\ International control machinery}

\section{The Conference,}

Considering the importance of facilitating the transitional arrangements provided for in article 45 of the Single Convention on Narcotic Drugs, 1961,

Invites the Economic and Social Council to study the possibility of taking measures which would ensure the rapid and smooth carrying out of the simplification of the international control machinery. 


\section{Final Act of the United Nations Conference to consider amendments to the Single Convention on Narcotic Drugs, 1961}

1. The Economic and Social Council of the United Nations, noting that amendments had been proposed to the Single Convention on Narcotic Drugs, 1961 , and bearing in mind article 47 of that Convention, decided by its resolution 1577 (L) of 21 May 1971 to call, in accordance with Article 62, paragraph 4, of the Charter of the United Nations, a conference of plenipotentiaries to consider all amendments proposed to the Single Convention on Narcotic Drugs, 1961.

2. The United Nations Conference to consider amendments to the Single Convention on Narcotic Drugs, 1961, met at the United Nations Office at Geneva from 6 to 24 March 1972.

3. The following 97 States were represented by representatives at the Conference:

\begin{tabular}{lll} 
Afghanistan & Saudi Arabia & Gambia \\
Algeria & Colombia & Ghana \\
Argentina & Costa Rica & Greece \\
Australia & Cuba & Guatemala \\
Austria & Cyprus & Haiti \\
Belgium & Czechoslovakia & Holy See \\
Bolivia & Dahomey & Hungary \\
Brazil & Denmark & India \\
Bulgaria & Ecuador & Indonesia \\
Burma & Egypt & Iran \\
Burundi & El Salvador & Iraq \\
Byelorussian Soviet & Federal Republic of & Ireland \\
\multicolumn{1}{c}{ Socialist Republic } & Germany & Israel \\
Canada & Finland & Italy \\
Ceylon & France & Ivory Coast \\
Chile & Gabon & Jamaica \\
& &
\end{tabular}




$\begin{array}{lll}\text { Japan } & \text { New Zealand } & \text { Sudan } \\ \text { Jordan } & \text { Nicaragua } & \text { Sweden } \\ \text { Kenya } & \text { Niger } & \text { Switzerland } \\ \text { Khmer Republic } & \text { Nigeria } & \text { Thailand } \\ \text { Kuwait } & \text { Norway } & \text { Togo } \\ \text { Laos } & \text { Pakistan } & \text { Tunisia } \\ \text { Lebanon } & \text { Panama } & \text { Turkey } \\ \text { Liberia } & \text { Peru } & \text { Ukrainian Soviet } \\ \text { Libyan Arab Republic } & \text { Philippines } & \text { Socialist Republic } \\ \text { Liechtenstein } & \text { Poland } & \text { Union of Soviet } \\ \text { Luxembourg } & \text { Portugal } & \text { Socialist Republics } \\ \text { Madagascar } & \text { Republic of Korea } & \text { United Kingdom of } \\ \text { Malawi } & \text { Republic of Viet-Nam } & \text { Great Britain and } \\ \text { Mexico } & \text { Saudi Arabia } & \text { Northern Ireland } \\ \text { Monaco } & \text { Senegal } & \text { United States of } \\ \text { Mongolian People's } & \text { Sierra Leone } & \text { America } \\ \text { Republic } & \text { Singapore } & \text { Uruguay } \\ \text { Morocco } & \text { South Africa } & \text { Venezuela } \\ \text { Netherlands } & \text { Spain } & \text { Yugoslavia } \\ \end{array}$

4. The following States were represented by observers at the Conference:

$\begin{array}{lll}\text { Cameroon } & \text { Malaysia } & \text { Romania } \\ \text { Dominican Republic } & \text { Malta } & \end{array}$

5. The Economic and Social Council, by its resolution 1577 (L), requested the Secretary-General to invite to the Conference the World Health Organization and other interested specialized agencies, the International Narcotics Control Board and the International Criminal Police Organization. The World Health Organization, the International Narcotics Control Board and the International Criminal Police Organization were represented at the Conference.

6. The Conference elected Mr. K. B. Asante (Ghana) as President of the Conference, Mr. D. Nikolić (Yugoslavia) as First Vice-President, and as the other Vice-Presidents the representatives of the following States: 


$\begin{array}{llr}\text { Argentina } & \text { Lebanon } & \text { United Kingdom of } \\ \text { Egypt } & \text { Mexico } & \text { Great Britain and } \\ \text { France } & \text { Turkey } & \text { Northern Ireland } \\ \text { India } & \text { Union of Soviet } & \text { United States of } \\ & \text { Socialist Republics } & \text { America }\end{array}$

7. Mr. V. Winspeare-Guicciardi, Director-General of the United Nations Office at Geneva, was the representative of the Secretary-General of the United Nations. The Executive Secretary of the Conference was Dr. V. Kušević, the Legal Adviser of the Conference was Mr. G. Wattles and the Deputy Executive Secretary and Deputy Legal Adviser was Mr. P. Raton.

8. The Conference had before it the amendments to the Single Convention on Narcotic Drugs, 1961, which were proposed by States participating in the Conference.

9. The Conference set up the following committees:

General Committee

Chairman: The President of the Conference

Committee I

Chairman: Dr. R. A. Chapman (Canada)

Committee II

Chairman: Dr. Béla Bölcs (Hungary)

Drafting Committee

Chairman: Mr. J-P, Bertschinger (Switzerland)

Credentials Committee

Chairman: Mr. J. W. Lennon (Ireland)

10. Committee I established a working group on article 14, the Chairman of which was Mr. A. C. Kirca (Turkey). 
11. As a result of its deliberations, as recorded in the summary records of the Plenary and Committees I and II, the Conference adopted and opened for signature the Protocol amending the Single Convention on Narcotic Drugs, 1961. In addition, the Conference adopted three resolutions annexed to this Final Act.

DONE at Geneva, this twenty-fifth day of March, one thousand nine hundred and seventy-two, in a single copy in the English, French, Russian and Spanish languages, each text being equally authentic. The original text shall be deposited with the Secretary-General of the United Nations.

IN WITNESS WHEREOF the representatives have signed this Final Act. 


\title{
Resolutions adopted by the United Nations Conference to consider amendments to the Single Convention on Narcotic Drugs, 1961
}

\author{
Resolution I \\ Secretariat of the International \\ Narcotics Control Board
}

The Conference,

Considering that the measures adopted by the Economic and Social Council in its resolution 1196 (XLII) of 16 May 1967 (1464th plenary meeting) met the wishes of the States Parties to the Single Convention on Narcotic Drugs, 1961, and to the earlier conventions still in force,

Recommends the continuation of the system which was instituted by the Secretary-General of the United Nations and whose main provisions are as follows:

1. The International Narcotics Control Board (hereinafter referred to as the Board) has a secretariat distinct from the Division of Narcotic Drugs;

2. That secretariat is an integral part of the Secretariat of the United Nations; while under the full administrative control of the SecretaryGeneral, it is bound to carry out the decisions of the Board;

3. The members of the secretariat are appointed or assigned by the Secretary-General; the head of that secretariat is appointed or assigned in consultation with the Board.

\section{Resolution II \\ Assistance in narcotics control}

The Conference,

Recalling that assistance to developing countries is a concrete manifestation of the will of the international community to honour the commitment 
contained in the United Nations Charter to promote the social and economic progress of all peoples,

Recalling the special arrangements made by the United Nations General Assembly under its resolution 1395 (XIV) with a view to the provision of technical assistance for drug abuse control,

Welcoming the establishment pursuant to United Nations General Assembly resolution 2719 (XXV), of a United Nations Fund for Drug Abuse Control,

Noting that the Conference has adopted a new article 14 bis concerning technical and financial assistance to promote more effective execution of the provisions of the Single Convention on Narcotic Drugs, 1961,

1. Declares that, to be more effective, the measures taken against drug abuse must be co-ordinated and universal;

2. Declares further that the fulfilment by the developing countries of their obligations under the Convention will be facilitated by adequate technical and financial assistance from the international community.

\section{Resolution III \\ Social conditions and protection against drug addiction}

\section{The Conference,}

Recalling that the Preamble to the Single Convention on Narcotic Drugs, 1961, states that the Parties to the Convention are "concerned with the health and welfare of mankind" and are "conscious of their duty to prevent and combat" the evil of drug addiction,

Considering that the discussions at the Conference have given evidence of the desire to take effective steps to prevent drug addiction,

Considering that, while drug addiction leads to personal degradation and social disruption, it happens very often that the deplorable social and economic conditions in which certain individuals and certain groups are living predispose them to drug addiction, 
Recognizing that social factors have a certain and sometimes preponderant influence on the behaviour of individuals and groups,

Recommends that the Parties:

1. Should bear in mind that drug addiction is often the result of an unwholesome social atmosphere in which those who are most exposed to the danger of drug abuse live;

2. Should do everything in their power to combat the spread of the illicit use of drugs;

3. Should develop leisure and other activities conducive to the sound physical and psychological health of young people. 



\title{
Single Convention on Narcotic Drugs, 1961, as amended by the 1972 Protocol amending the Single Convention on Narcotic Drugs, 1961
}

\author{
Preamble
}

The Parties,

Concerned with the health and welfare of mankind,

Recognizing that the medical use of narcotic drugs continues to be indispensable for the relief of pain and suffering and that adequate provision must be made to ensure the availability of narcotic drugs for such purposes,

Recognizing that addiction to narcotic drugs constitutes a serious evil for the individual and is fraught with social and economic danger to mankind,

Conscious of their duty to prevent and combat this evil,

Considering that effective measures against abuse of narcotic drugs require co-ordinated and universal action,

Understanding that such universal action calls for international co-operation guided by the same principles and aimed at common objectives,

Acknowledging the competence of the United Nations in the field of narcotics control and desirous that the international organs concerned should be within the framework of that Organization,

Desiring to conclude a generally acceptable international convention replacing existing treaties on narcotic drugs, limiting such drugs to medical and scientific use, and providing for continuous international co-operation and control for the achievement of such aims and objectives, 
Hereby agree as follows: ${ }^{2}$

\section{Article 1. Definitions}

1. Except where otherwise expressly indicated or where the context otherwise requires, the following definitions shall apply throughout the Convention:

(a) "Board" means the International Narcotics Control Board.

(b) "Cannabis" means the flowering or fruiting tops of the cannabis plant (excluding the seeds and leaves when not accompanied by the tops) from which the resin has not been extracted, by whatever name they may be designated.

(c) "Cannabis plant" means any plant of the genus Cannabis.

(d) "Cannabis resin" means the separated resin, whether crude or purified, obtained from the cannabis plant.

(e) "Coca bush" means the plant of any species of the genus Erythroxylon.

(f) "Coca leaf" means the leaf of the coca bush except a leaf from which all ecgonine, cocaine and any other ecgonine alkaloids have been removed.

(g) "Commission" means the Commission on Narcotic Drugs of the Council.

(b) "Council" means the Economic and Social Council of the United Nations.

(i) "Cultivation" means the cultivation of the opium poppy, coca bush or cannabis plant.

(j) "Drug" means any of the substances in Schedules I and II, whether natural or synthetic.

(k) "General Assembly" means the General Assembly of the United Nations.

${ }^{2}$ Note by the Secretariat: The Preamble to the Protocol Amending the Single Convention on Narcotic Drugs, 1961, reads as follows:

"The Parties to the Present Protocol,

"Considering the provisions of the Single Convention on Narcotic Drugs, 1961, done at New York on 30 March 1961 (hereinafter called the Single Convention),

"Desiring to amend the Single Convention

"Have agreed as follows:" 
(l) "Illicit traffic" means cultivation or trafficking in drugs contrary to the provisions of this Convention.

(m) "Import" and "export" mean in their respective connotations the physical transfer of drugs from one State to another State, or from one territory to another territory of the same State.

(n) "Manufacture" means all processes, other than production, by which drugs may be obtained and includes refining as well as the transformation of drugs into other drugs.

(o) "Medicinal opium" means opium which has undergone the processes necessary to adapt it for medicinal use.

(p) “Opium" means the coagulated juice of the opium poppy.

(q) “Opium poppy" means the plant of the species Papaver somniferum L.

(r) "Poppy straw" means all parts (except the seeds) of the opium poppy, after mowing.

(s) "Preparation" means a mixture, solid or liquid, containing a drug.

(t) "Production" means the separation of opium, coca leaves, cannabis and cannabis resin from the plants from which they are obtained.

(u) "Schedule I", "Schedule II", "Schedule III" and "Schedule IV" mean the correspondingly numbered list of drugs or preparations annexed to this Convention, as amended from time to time in accordance with article 3.

(v) "Secretary-General" means the Secretary-General of the United Nations.

(w) "Special stocks" means the amounts of drugs held in a country or territory by the Government of such country or territory for special government purposes and to meet exceptional circumstances; and the expression "special purposes" shall be construed accordingly.

(x) "Stocks" means the amounts of drugs held in a country or territory and intended for:

(i) Consumption in the country or territory for medical and scientific purposes,

(ii) Utilization in the country or territory for the manufacture of drugs and other substances, or 
(iii) Export;

but does not include the amounts of drugs held in the country or territory,

(iv) By retail pharmacists or other authorized retail distributors and by institutions or qualified persons in the duly authorized exercise of therapeutic or scientific functions, or

(v) As "special stocks".

(y) "Territory" means any part of a State which is treated as a separate entity for the application of the system of import certificates and export authorizations provided for in article 31. This definition shall not apply to the term "territory" as used in articles 42 and 46.

2. For the purposes of this Convention a drug shall be regarded as "consumed" when it has been supplied to any person or enterprise for retail distribution, medical use or scientific research; and "consumption" shall be construed accordingly.

\section{Article 2. Substances under control}

1. Except as to measures of control which are limited to specified drugs, the drugs in Schedule I are subject to all measures of control applicable to drugs under this Convention and in particular to those prescribed in article 4 (c), 19, $20,21,29,30,31,32,33,34$ and 37.

2. The drugs in Schedule II are subject to the same measures of control as drugs in Schedule I with the exception of the measures prescribed in article 30 , paragraphs 2 and 5, in respect of the retail trade.

3. Preparations other than those in Schedule III are subject to the same measures of control as the drugs which they contain, but estimates (article 19) and statistics (article 20) distinct from those dealing with these drugs shall not be required in the case of such preparations, and article 29, paragraph 2 (c) and article 30, paragraph 1 (b) (ii) need not apply.

4. Preparations in Schedule III are subject to the same measures of control as preparations containing drugs in Schedule II except that article 31, 
paragraphs 1 (b) and 3 to 15 and, as regards their acquisition and retail distribution, article 34, paragraph (b), need not apply, and that for the purpose of estimates (article 19) and statistics (article 20) the information required shall be restricted to the quantities of drugs used in the manufacture of such preparations.

5. The drugs in Schedule IV shall also be included in Schedule I and subject to all measures of control applicable to drugs in the latter Schedule, and in addition thereto:

(a) A Party shall adopt any special measures of control which in its opinion are necessary having regard to the particularly dangerous properties of a drug so included; and

(b) A Party shall, if in its opinion the prevailing conditions in its country render it the most appropriate means of protecting the public health and welfare, prohibit the production, manufacture, export and import of, trade in, possession or use of any such drug except for amounts which may be necessary for medical and scientific research only, including clinical trials therewith to be conducted under or subject to the direct supervision and control of the Party.

6. In addition to the measures of control applicable to all drugs in Schedule I, opium is subject to the provisions of article 19, paragraph 1, subparagraph $(f)$, and of articles 21 bis, 23 and 24, the coca leaf to those of articles 26 and 27 and cannabis to those of article 28.

7. The opium poppy, the coca bush, the cannabis plant, poppy straw and cannabis leaves are subject to the control measures prescribed in article 19, paragraph 1, subparagraph (e), article 20, paragraph 1, subparagraph (g), article 21 bis and in articles 22 to 24;22, 26 and 27; 22 and 28;25; and 28, respectively:

8. The Parties shall use their best endeavours to apply to substances which do not fall under this Convention, but which may be used in the illicit manufacture of drugs, such measures of supervision as may be practicable.

9. Parties are not required to apply the provisions of this Convention to drugs which are commonly used in industry for other than medical or scientific purposes, provided that:

(a) They ensure by appropriate methods of denaturing or by other means that the drugs so used are not liable to be abused or have ill effects (article 3 , 
paragraph 3) and that the harmful substances cannot in practice be recovered; and

(b) They include in the statistical information (article 20) furnished by them the amount of each drug so used.

\section{Article 3. Changes in the scope of control}

1. Where a Party or the World Health Organization has information which in its opinion may require an amendment to any of the Schedules, it shall notify the Secretary-General and furnish him with the information in support of the notification.

2. The Secretary-General shall transmit such notification, and any information which he considers relevant, to the Parties, to the Commission, and, where the notification is made by a Party, to the World Health Organization.

3. Where a notification relates to a substance not already in Schedule I or in Schedule II,

(i) The Parties shall examine in the light of the available information the possibility of the provisional application to the substance of all measures of control applicable to drugs in Schedule I;

(ii) Pending its decision as provided in subparagraph (iii) of this paragraph, the Commission may decide that the Parties apply provisionally to that substance all measures of control applicable to drugs in Schedule I. The Parties shall apply such measures provisionally to the substance in question;

(iii) If the World Health Organization finds that the substance is liable to similar abuse and productive of similar ill effects as the drugs in Schedule I or Schedule II or is convertible into a drug, it shall communicate that finding to the Commission which may, in accordance with the recommendation of the World Health Organization, decide that the substance shall be added to Schedule I or Schedule II.

4. If the World Health Organization finds that a preparation because of the substances which it contains is not liable to abuse and cannot produce 
ill effects (paragraph 3) and that the drug therein is not readily recoverable, the Commission may, in accordance with the recommendation of the World Health Organization, add that preparation to Schedule III.

5. If the World Health Organization finds that a drug in Schedule I is particularly liable to abuse and to produce ill effects (paragraph 3 ) and that such liability is not offset by substantial therapeutic advantages not possessed by substances other than drugs in Schedule IV, the Commission may, in accordance with the recommendation of the World Health Organization, place that drug in Schedule IV.

6. Where a notification relates to a drug already in Schedule I or Schedule II or to a preparation in Schedule III, the Commission, apart from the measure provided for in paragraph 5, may, in accordance with the recommendation of the World Health Organization, amend any of the Schedules by:

(a) Transferring a drug from Schedule I to Schedule II or from Schedule II to Schedule I; or

(b) Deleting a drug or a preparation as the case may be, from a Schedule.

7. Any decision of the Commission taken pursuant to this article shall be communicated by the Secretary-General to all States Members of the United Nations, to non-member States Parties to this Convention, to the World Health Organization and to the Board. Such decision shall become effective with respect to each Party on the date of its receipt of such communication, and the Parties shall thereupon take such action as may be required under this Convention.

8. (a) The decisions of the Commission amending any of the Schedules shall be subject to review by the Council upon the request of any Party filed within ninety days from receipt of notification of the decision. The request for review shall be sent to the Secretary-General together with all relevant information upon which the request for review is based;

(b) The Secretary-General shall transmit copies of the request for review and relevant information to the Commission, the World Health Organization and to all the Parties inviting them to submit comments within ninety days. All comments received shall be submitted to the Council for consideration; 
(c) The Council may confirm, alter or reverse the decision of the Commission, and the decision of the Council shall be final. Notification of the Council's decision shall be transmitted to all States Members of the United Nations, to non-member States Parties to this Convention, to the Commission, to the World Health Organization, and to the Board;

(d) During pendency of the review the original decision of the Commission shall remain in effect.

9. Decisions of the Commission taken in accordance with this article shall not be subject to the review procedure provided for in article 7 .

\section{Article 4. General obligations}

The parties shall take such legislative and administrative measures as may be necessary:

(a) To give effect to and carry out the provisions of this Convention within their own territories;

(b) To co-operate with other States in the execution of the provisions of this Convention; and

(c) Subject to the provisions of this Convention, to limit exclusively to medical and scientific purposes the production, manufacture, export, import, distribution of, trade in, use and possession of drugs.

\section{Article 5. The international control organs}

The Parties, recognizing the competence of the United Nations with respect to the international control of drugs, agree to entrust to the Commission on Narcotic Drugs of the Economic and Social Council, and to the International Narcotics Control Board, the functions respectively assigned to them under this Convention.

\section{Article 6. Expenses of the international control organs}

The expenses of the Commission and the Board will be borne by the United Nations in such manner as shall be decided by the General Assembly. The Parties 
which are not Members of the United Nations shall contribute to these expenses such amounts as the General Assembly finds equitable and assess from time to time after consultation with the Governments of these Parties.

\section{Article 7. Review of decisions and recommendations of the Commission}

Except for decisions under article 3, each decision or recommendation adopted by the Commission pursuant to the provisions of this Convention shall be subject to approval or modification by the Council or the General Assembly in the same way as other decisions or recommendations of the Commission.

\section{Article 8. Functions of the Commission}

The Commission is authorized to consider all matters pertaining to the aims of this Convention, and in particular:

(a) To amend the Schedules in accordance with article 3;

(b) To call the attention of the Board to any matters which may be relevant to the functions of the Board;

(c) To make recommendations for the implementation of the aims and provisions of this Convention, including programmes of scientific research and the exchange of information of a scientific or technical nature; and

(d) To draw the attention of non-parties to decisions and recommendations which it adopts under this Convention, with a view to their considering taking action in accordance therewith.

\section{Article 9. Composition and functions of the Board}

1. The Board shall consist of thirteen members to be elected by the Council as follows:

(a) Three members with medical, pharmacological or pharmaceutical experience from a list of at least five persons nominated by the World Health Organization; and 
(b) Ten members from a list of persons nominated by the Members of the United Nations and by Parties which are not Members of the United Nations.

2. Members of the Board shall be persons who, by their competence, impartiality and disinterestedness, will command general confidence. During their term of office they shall not hold any position or engage in any activity which would be liable to impair their impartiality in the exercise of their functions. The Council shall, in consultation with the Board, make all arrangements necessary to ensure the full technical independence of the Board in carrying out its functions.

3. The Council, with due regard to the principle of equitable geographic representation, shall give consideration to the importance of including on the Board, in equitable proportion, persons possessing a knowledge of the drug situation in the producing, manufacturing, and consuming countries, and connected with such countries.

4. The Board, in co-operation with Governments, and subject to the terms of this Convention, shall endeavour to limit the cultivation, production, manufacture and use of drugs to an adequate amount required for medical and scientific purposes, to ensure their availability for such purposes and to prevent illicit cultivation, production and manufacture of, and illicit trafficking in and use of, drugs.

5. All measures taken by the Board under this Convention shall be those most consistent with the intent to further the co-operation of Governments with the Board and to provide the mechanism for a continuing dialogue between Governments and the Board which will lend assistance to and facilitate effective national action to attain the aims of this Convention.

\section{Article 10. Terms of office and remuneration of members of the Board}

1. The members of the Board shall serve for a period of five years, and may be re-elected.

2. The term of office of each member of the Board shall end on the eve of the first meeting of the Board which his successor shall be entitled to attend. 
3. A member of the Board who has failed to attend three consecutive sessions shall be deemed to have resigned.

4. The Council, on the recommendation of the Board, may dismiss a member of the Board who has ceased to fulfil the conditions required for membership by paragraph 2 of article 9 . Such recommendation shall be made by an affirmative vote of nine members of the Board.

5. Where a vacancy occurs on the Board during the term of office of a member, the Council shall fill such vacancy as soon as possible and in accordance with the applicable provisions of article 9, by electing another member for the remainder of the term.

6. The members of the Board shall receive an adequate remuneration as determined by the General Assembly.

\section{Article 11. Rules of procedure of the Board}

1. The Board shall elect its own President and such other officers as it may consider necessary and shall adopt its rules of procedure.

2. The Board shall meet as often as, in its opinion, may be necessary for the proper discharge of its functions, but shall hold at least two sessions in each calendar year.

3. The quorum necessary at meetings of the Board shall consist of eight members.

\section{Article 12. Administration of the estimate system}

1. The Board shall fix the date or dates by which, and the manner in which, the estimates as provided in article 19 shall be furnished and shall prescribe the forms therefor.

2. The Board shall, in respect of countries and territories to which this Convention does not apply, request the Governments concerned to furnish estimates in accordance with the provisions of this Convention. 
3. If any State fails to furnish estimates in respect of any of its territories by the date specified, the Board shall, as far as possible, establish the estimates. The Board in establishing such estimates shall to the extent practicable do so in co-operation with the Government concerned.

4. The Board shall examine the estimates, including supplementary estimates, and, except as regards requirements for special purposes, may require such information as it considers necessary in respect of any country or territory on behalf of which an estimate has been furnished, in order to complete the estimate or to explain any statement contained therein.

5. The Board, with a view to limiting the use and distribution of drugs to an adequate amount required for medical and scientific purposes and to ensuring their availability for such purposes, shall as expeditiously as possible confirm the estimates, including supplementary estimates, or, with the consent of the Government concerned, may amend such estimates. In case of a disagreement between the Government and the Board, the latter shall have the right to establish, communicate and publish its own estimates, including supplementary estimates.

6. In addition to the reports mentioned in article 15, the Board shall, at such times as it shall determine but at least annually, issue such information on the estimates as in its opinion will facilitate the carrying out of this Convention.

\section{Article 13. Administration of the statistical returns system}

1. The Board shall determine the manner and form in which statistical returns shall be furnished as provided in article 20 and shall prescribe the forms therefor.

2. The Board shall examine the returns with a view to determining whether a Party or any other State has complied with the provisions of this Convention.

3. The Board may require such further information as it considers necessary to complete or explain the information contained in such statistical returns.

4. It shall not be within the competence of the Board to question or express an opinion on statistical information respecting drugs required for special purposes. 


\section{Article 14. Measures by the Board to ensure the execution of provisions of the Convention}

1. (a) If, on the basis of its examination of information submitted by Governments to the Board under the provisions of this Convention, or of information communicated by United Nations organs or by specialized agencies or, provided that they are approved by the Commission on the Board's recommendation, by either other intergovernmental organizations or international nongovernmental organizations which have direct competence in the subject matter and which are in consultative status with the Economic and Social Council under Article 71 of the Charter of the United Nations or which enjoy a similar status by special agreement with the Council, the Board has objective reasons to believe that the aims of this Convention are being seriously endangered by reason of the failure of any Party, country or territory to carry out the provisions of this Convention, the Board shall have the right to propose to the Government concerned the opening of consultations or to request it to furnish explanations. If, without any failure in implementing the provisions of the Convention, a Party or a country or territory has become, or if there exists evidence of a serious risk that it may become, an important centre of illicit cultivation, production or manufacture of, or traffic in or consumption of drugs, the Board has the right to propose to the Government concerned the opening of consultations. Subject to the right of the Board to call the attention of the Parties, the Council and the Commission to the matter referred to in subparagraph (d) below, the Board shall treat as confidential a request for information and an explanation by a Government or a proposal for consultations and the consultations held with a Government under this subparagraph.

(b) After taking action under subparagraph (a) above, the Board, if satisfied that it is necessary to do so, may call upon the Government concerned to adopt such remedial measures as shall seem under the circumstances to be necessary for the execution of the provisions of this Convention.

(c) The Board may, if it thinks such action necessary, for the purpose of assessing a matter referred to in subparagraph (a) of this paragraph, propose to the Government concerned that a study of the matter be carried out in its territory by such means as the Government deems appropriate. If the Government concerned decides to undertake this study, it may request the Board to make available the expertise and the services of one or more persons with the requisite competence to assist the officials of the Government in the proposed study. The 
person or persons whom the Board intends to make available shall be subject to the approval of the Government. The modalities of this study and the time-limit within which the study has to be completed shall be determined by consultation between the Government and the Board. The Government shall communicate to the Board the results of the study and shall indicate the remedial measures that it considers necessary to take.

(d) If the Board finds that the Government concerned has failed to give satisfactory explanations when called upon to do so under subparagraph (a) above, or has failed to adopt any remedial measures which it has been called upon to take under subparagraph (b) above, or that there is a serious situation that needs co-operative action at the international level with a view to remedying it, it may call the attention of the Parties, the Council and the Commission to the matter. The Board shall so act if the aims of this Convention are being seriously endangered and it has not been possible to resolve the matter satisfactorily in any other way. It shall also so act if it finds that there is a serious situation that needs co-operative action at the international level with a view to remedying it and that bringing such a situation to the notice of the Parties, the Council and the Commission is the most appropriate method of facilitating such co-operative action; after considering the reports of the Board, and of the Commission if available on the matter, the Council may draw the attention of the General Assembly to the matter.

2. The Board, when calling the attention of the Parties, the Council and the Commission to a matter in accordance with paragraph 1 (d) above, may, if it is satisfied that such a course is necessary, recommend to Parties that they stop the import of drugs, the export of drugs, or both, from or to the country or territory concerned, either for a designated period or until the Board shall be satisfied as to the situation in that country or territory. The State concerned may bring the matter before the Council.

3. The Board shall have the right to publish a report on any matter dealt with under the provisions of this article, and communicate it to the Council, which shall forward it to all Parties. If the Board publishes in this report a decision taken under this article or any information relating thereto, it shall also publish therein the views of the Government concerned if the latter so requests.

4. If in any case a decision of the Board which is published under this article is not unanimous, the views of the minority shall be stated. 
5. Any State shall be invited to be represented at a meeting of the Board at which a question directly interesting it is considered under this article.

6. Decisions of the Board under this article shall be taken by a twothirds majority of the whole number of the Board.

\section{Article 14 bis. Technical and financial assistance}

In cases which it considers appropriate and either in addition or as an alternative to measures set forth in article 14, paragraphs 1 and 2, the Board, with the agreement of the Government concerned, may recommend to the competent United Nations organs and to the specialized agencies that technical or financial assistance, or both, be provided to the Government in support of its efforts to carry out its obligations under this Convention, including those set out or referred to in articles 2, 35, 38 and 38 bis.

\section{Article 15. Reports of the Board}

1. The Board shall prepare an annual report on its work and such additional reports as it considers necessary containing also an analysis of the estimates and statistical information at its disposal, and, in appropriate cases, an account of the explanations, if any, given by or required of Governments, together with any observations and recommendations which the Board desires to make. These reports shall be submitted to the Council through the Commission, which may make such comments as it sees fit.

2. The reports shall be communicated to the Parties and subsequently published by the Secretary-General. The Parties shall permit their unrestricted distribution.

\section{Article 16. Secretariat}

The secretariat services of the Commission and the Board shall be furnished by the Secretary-General. In particular, the Secretary of the Board shall be appointed by the Secretary-General in consultation with the Board. 


\section{Article 17. Special administration}

The Parties shall maintain a special administration for the purpose of applying the provisions of this Convention.

\section{Article 18. Information to be furnished by Parties to the Secretary-General}

1. The Parties shall furnish to the Secretary-General such information as the Commission may request as being necessary for the performance of its functions, and in particular:

(a) An annual report on the working of the Convention within each of their territories;

(b) The text of all laws and regulations from time to time promulgated in order to give effect to this Convention;

(c) Such particulars as the Commission shall determine concerning cases of illicit traffic, including particulars of each case of illicit traffic discovered which may be of importance, because of the light thrown on the source from which drugs are obtained for the illicit traffic, or because of quantities involved or the method employed by illicit traffickers; and

(d) The, names and addresses of the governmental authorities empowered to issue export and import authorizations or certificates.

2. Parties shall furnish the information referred to in the preceding paragraph in such manner and by such dates and use such forms as the Commission may request.

\section{Article 19. Estimates of drug requirements}

1. The Parties shall furnish to the Board each year for each of their territories, in the manner and form prescribed by the Board, estimates on forms supplied by it in respect of the following matters:

(a) Quantities of drugs to be consumed for medical and scientific purposes; 
(b) Quantities of drugs to be utilized for the manufacture of other drugs, of preparations in Schedule III, and of substances not covered by this Convention;

(c) Stocks of drugs to be held as at 31 December of the year to which the estimates relate;

(d) Quantities of drugs necessary for addition to special stocks;

(e) The area (in hectares) and the geographical location of land to be used for the cultivation of the opium poppy;

(f) Approximate quantity of opium to be produced;

(g) The number of industrial establishments which will manufacture synthetic drugs; and

(b) The quantities of synthetic drugs to be manufactured by each of the establishments referred to in the preceding subparagraph.

2. (a) Subject to the deductions referred to in paragraph 3 of article 21, the total of the estimates for each territory and each drug except opium and synthetic drugs shall consist of the sum of the amounts specified under subparagraphs (a), (b) and (d) of paragraph 1 of this article, with the addition of any amount required to bring the actual stocks on hand at 31 December of the preceding year to the level estimated as provided in subparagraph (c) of paragraph 1 ;

(b) Subject to the deductions referred to in paragraph 3 of article 21 regarding imports and in paragraph 2 of article 21 bis, the total of the estimates for opium for each territory shall consist either of the sum of the amounts specified under subparagraphs (a), (b) and (d) of paragraph 1 of this article, with the addition of any amount required to bring the actual stocks on hand at 31 December of the preceding year to the level estimated as provided in subparagraph $(c)$ of paragraph 1 , or of the amount specified under subparagraph $(f)$ of paragraph 1 of this article, whichever is higher.

(c) Subject to the deductions referred to in paragraph 3 of article 21, the total of the estimates for each territory for each synthetic drug shall consist either of the sum of the amounts specified under subparagraphs (a), (b) and (d) of paragraph 1 of this article, with the addition of any amount required to bring the actual stocks on hand at 31 December of the preceding year to the level estimated as provided in subparagraph (c) of paragraph 1, or of the sum of the 
amounts specified under subparagraph (h) of paragraph 1 of this article, whichever is higher.

(d) The estimates furnished under the preceding subparagraphs of this paragraph shall be appropriately modified to take into account any quantity seized and thereafter released for licit use as well as any quantity taken from special stocks for the requirements of the civilian population.

3. Any State may during the year furnish supplementary estimates with an explanation of the circumstances necessitating such estimates.

4. The Parties shall inform the Board of the method used for determining quantities shown in the estimates and of any changes in the said method.

5. Subject to the deductions referred to in paragraph 3 of article 21, and account being taken where appropriate of the provisions of article $21 \mathrm{bis}$, the estimates shall not be exceeded.

\section{Article 20. Statistical returns to be furnished to the Board}

1. The Parties shall furnish to the Board for each of their territories, in the manner and form prescribed by the Board, statistical returns on forms supplied by it in respect of the following matters:

(a) Production or manufacture of drugs;

(b) Utilization of drugs for the manufacture of other drugs, of preparations in Schedule III and of substances not covered by this Convention, and utilization of poppy straw for the manufacture of drugs;

(c) Consumption of drugs;

(d) Imports and exports of drugs and poppy straw;

(e) Seizures of drugs and disposal thereof;

(f) Stocks of drugs as at 31 December of the year to which the returns relate; and

(g) Ascertainable area of cultivation of the opium poppy. 
2. (a) The statistical returns in respect of the matters referred to in paragraph 1 , except subparagraph $(d)$, shall be prepared annually and shall be furnished to the Board not later than 30 June following the year to which they relate.

(b) The statistical returns in respect to the matters referred to in subparagraph (d) of paragraph 1 shall be prepared quarterly and shall be furnished to the Board within one month after the end of the quarter to which they relate.

3. The Parties are not required to furnish statistical returns respecting special stocks, but shall furnish separately returns respecting drugs imported into or procured within the country or territory for special purposes, as well as quantities of drugs withdrawn from special stocks to meet the requirements of the civilian population.

\section{Article 21. Limitation of manufacture and importation}

1. The total of the quantities of each drug manufactured and imported by any country or territory in any one year shall not exceed the sum of the following:

(a) The quantity consumed, within the limit of the relevant estimate, for medical and scientific purposes;

(b) The quantity used, within the limit of the relevant estimate, for the manufacture of other drugs, of preparations in Schedule III, and of substances not covered by this Convention;

(c) The quantity exported;

(d) The quantity added to the stock for the purpose of bringing that stock up to the level specified in the relevant estimate; and

(e) The quantity acquired within the limit of the relevant estimate for special purposes.

2. From the sum of the quantities specified in paragraph 1 there shall be deducted any quantity that has been seized and released for licit use, as well as any quantity taken from special stocks for the requirements of the civilian population.

3. If the Board finds that the quantity manufactured and imported in any one year exceeds the sum of the quantities specified in paragraph 1, less any 
deductions required under paragraph 2 of this article, any excess so established and remaining at the end of the year shall, in the following year, be deducted from the quantity to be manufactured or imported and from the total of the estimates as defined in paragraph 2 of article 19.

4. (a) If it appears from the statistical returns on imports or exports (article 20) that the quantity exported to any country or territory exceeds the total of the estimates for that country or territory, as defined in paragraph 2 of article 19, with the addition of the amounts shown to have been exported, and after deduction of any excess as established in paragraph 3 of this article, the Board may notify this fact to States which, in the opinion of the Board, should be so informed

(b) On receipt of such a notification, Parties shall not during the year in question authorize any further exports of the drug concerned to that country or territory, except:

(i) In the event of a supplementary estimate being furnished for that country or territory in respect both of any quantity overimported and of the additional quantity required, or

(ii) In exceptional cases where the export, in the opinion of the Government of the exporting country, is essential for the treatment of the sick.

\section{Article 21 bis. Limitation of production of opium}

1. The production of opium by any country or territory shall be organized and controlled in such manner as to ensure that, as far as possible, the quantity produced in any one year shall not exceed the estimate of opium to be produced as established under paragraph $1(f)$ of article 19.

2. If the Board finds on the basis of information at its disposal in accordance with the provisions of this Convention that a Party which has submitted an estimate under paragraph $1(f)$ of article 19 has not limited opium produced within its borders to licit purposes in accordance with relevant estimates and that a significant amount of opium produced, whether licitly or illicitly, within the borders of such a Party, has been introduced into the illicit traffic, it may, after studying the explanations of the Party concerned, which shall be submitted to it within 
one month after notification of the finding in question, decide to deduct all, or a portion, of such an amount from the quantity to be produced and from the total of the estimates as defined in paragraph 2 (b) of article 19 for the next year in which such a deduction can be technically accomplished, taking into account the season of the year and contractual commitments to export opium. This decision shall take effect ninety days after the Party concerned is notified thereof.

3. After notifying the Party concerned of the decision it has taken under paragraph 2 above with regard to a deduction, the Board shall consult with that Party in order to resolve the situation satisfactorily.

4. If the situation is not satisfactorily resolved, the Board may utilize the provisions of article 14 where appropriate.

5. In taking its decision with regard to a deduction under paragraph 2 above, the Board shall take into account not only all relevant circumstances including those giving rise to the illicit traffic problem referred to in paragraph 2 above, but also any relevant new control measures which may have been adopted by the Party.

\section{Article 22. Special provision applicable to cultivation}

1. Whenever the prevailing conditions in the country or a territory of a Party render the prohibition of the cultivation of the opium poppy, the coca bush or the cannabis plant the most suitable measure, in its opinion, for protecting the public health and welfare and preventing the diversion of drugs into the illicit traffic, the Party concerned shall prohibit cultivation.

2. A Party prohibiting cultivation of the opium poppy or the cannabis plant shall take appropriate measures to seize any plants illicitly cultivated and to destroy them, except for small quantities required by the Party for scientific or research purposes.

\section{Article 23. National opium agencies}

1. A Party that permits the cultivation of the opium poppy for the production of opium shall establish, if it has not already done so, and maintain, one 
or more government agencies (hereafter in this article referred to as the Agency) to carry out the functions required under this article.

2. Each such Party shall apply the following provisions to the cultivation of the opium poppy for the production of opium and to opium:

(a) The Agency shall designate the areas in which, and the plots of land on which, cultivation of the opium poppy for the purpose of producing opium shall be permitted.

(b) Only cultivators licensed by the Agency shall be authorized to engage in such cultivation.

(c) Each licence shall specify the extent of the land on which the cultivation is permitted.

(d) All cultivators of the opium poppy shall be required to deliver their total crops of opium to the Agency. The Agency shall purchase and take physical possession of such crops as soon as possible, but not later than four months after the end of the harvest.

(e) The Agency shall, in respect of opium, have the exclusive right of importing, exporting, wholesale trading and maintaining stocks other than those held by manufacturers of opium alkaloids, medicinal opium or opium preparations. Parties need not extend this exclusive right to medicinal opium and opium preparations.

3. The governmental functions referred to in paragraph 2 shall be discharged by a single government agency if the constitution of the Party concerned permits it.

\section{Article 24. Limitation on production of opium for international trade}

1. (a) If any Party intends to initiate the production of opium or to increase existing production, it shall take account of the prevailing world need for opium in accordance with the estimates thereof published by the Board so that the production of opium by such Party does not result in over-production of opium in the world. 
(b) A Party shall not permit the production of opium or increase the existing production thereof if in its opinion such production or increased production in its territory may result in illicit traffic in opium.

2. (a) Subject to paragraph 1, where a Party which as of 1 January 1961 was not producing opium for export desires to export opium which it produces, in amounts not exceeding five tons annually, it shall notify the Board, furnishing with such notification information regarding:

(i) The controls in force as required by this Convention respecting the opium to be produced and exported; and

(ii) The name of the country or countries to which it expects to export such opium;

and the Board may either approve such notification or may recommend to the Party that it not engage in the production of opium for export.

(b) Where a Party other than a party referred to in paragraph 3 desires to produce opium, for export in amounts exceeding five tons annually, it shall notify the Council, furnishing with such notification relevant information including:

(i) The estimated amounts to be produced for export;

(ii) The controls existing or proposed respecting the opium to be produced;

(iii) The name of the country or countries to which it expects to export such opium;

and the Council shall either approve the notification or may recommend to the Party that it not engage in the production of opium for export.

3. Notwithstanding the provisions of subparagraphs (a) and (b) of paragraph 2, a Party that during ten years immediately prior to 1 January 1961 exported opium which such country produced may continue to export opium which it produces.

4. (a) A Party shall not import opium from any country or territory except opium produced. in the territory of: 
(i) A Party referred to in paragraph 3;

(ii) A Party that has notified the Board as provided in subparagraph (a) of paragraph 2; or

(iii) A Party that has received the approval of the Council as provided in subparagraph (b) of paragraph 2.

(b) Notwithstanding subparagraph (a) of this paragraph, a Party may import opium produced by any country which produced and exported opium during the ten years prior to 1 January 1961 if such country has established and maintains a national control organ or agency for the purposes set out in article 23 and has in force an effective means of ensuring that the opium it produces is not diverted into the illicit traffic.

5. The provisions of this article do not prevent a Party:

(a) From producing opium sufficient for its own requirements; or

(b) From exporting opium seized in the illicit traffic, to another Party in accordance with the requirements of this Convention.

\section{Article 25. Control of poppy straw}

1. A Party that permits the cultivation of the opium poppy for purposes other than the production of opium shall take all measures necessary to ensure:

(a) That opium is not produced from such opium poppies; and

(b) That the manufacture of drugs from poppy straw is adequately controlled.

2. The Parties shall apply to poppy straw the system of import certificates and export authorizations as provided in article 31, paragraphs 4 to 15 .

3. The Parties shall furnish statistical information on the import and export of poppy straw as required for drugs under article 20, paragraphs 1 (d) and $2(b)$. 


\section{Article 26. The coca bush and coca leaves}

1. If a Party permits the cultivation of the coca bush, it shall apply thereto and to coca leaves the system of controls as provided in article 23 respecting the control of the opium poppy, but as regards paragraph 2 (d) of that article, the requirements imposed on the Agency therein referred to shall be only to take physical possession of the crops as soon as possible after the end of the harvest.

2. The Parties shall so far as possible enforce the uprooting of all coca bushes which grow wild. They shall destroy the coca bushes if illegally cultivated.

\section{Article 27. Additional provisions relating to coca leaves}

1. The Parties may permit the use of coca leaves for the preparation of a flavouring agent, which shall not contain any alkaloids, and, to the extent necessary for such use, may permit the production, import, export, trade in and possession of such leaves.

2. The Parties shall furnish separately estimates (article 19) and statistical information (article 20) in respect of coca leaves for preparation of the flavouring agent, except to the extent that the same coca leaves are used for the extraction of alkaloids and the flavouring agent, and so explained in the estimates and statistical information.

\section{Article 28. Control of cannabis}

1. If a Party permits the cultivation of the cannabis plant for the production of cannabis or cannabis resin, it shall apply thereto the system of controls as provided in article 23 respecting the control of the opium poppy.

2. This Convention shall not apply to the cultivation of the cannabis plant exclusively for industrial purposes (fibre and seed) or horticultural purposes.

3. The Parties shall adopt such measures as may be necessary to prevent the misuse of, and illicit traffic in, the leaves of the cannabis plant. 


\section{Article 29. Manufacture}

1. The Parties shall require that the manufacture of drugs be under licence except where such manufacture is carried out by a State enterprise or State enterprises.

2. The Parties shall:

(a) Control all persons and enterprises carrying on or engaged in the manufacture of drugs;

(b) Control under licence the establishments and premises in which such manufacture may take place; and

(c) Require that licensed manufacturers of drugs obtain periodical permits specifying the kinds and amounts of drugs which they shall be entitled to manufacture. A periodical permit, however, need not be required for preparations.

3. The Parties shall prevent the accumulation, in the possession of drug manufacturers, of quantities of drugs and poppy straw in excess of those required for the normal conduct of business, having regard to the prevailing market conditions.

\section{Article 30. Trade and distribution}

1. (a) The Parties shall require that the trade in and distribution of drugs be under licence except where such trade or distribution is carried out by a State enterprise or State enterprises:

(b) The Parties shall:

(i) Control all persons and enterprises carrying on or engaged in the trade in or distribution of drugs;

(ii) Control under licence the establishments and premises in which such trade or distribution may take place. The requirement of licensing need not apply to preparations. 
(c) The provisions of subparagraphs (a) and (b) relating to licensing need not apply to persons duly authorized to perform and while performing therapeutic or scientific functions.

2. The Parties shall also:

(a) Prevent the accumulation in the possession of traders, distributors, State enterprises or duly authorized persons referred to above, of quantities of drugs and poppy straw in excess of those required for the normal conduct of business, having regard to the prevailing market conditions; and

(b) (i) Require medical prescriptions for the supply or dispensation of drugs to individuals. This requirement need not apply to such drugs as individuals may lawfully obtain, use, dispense or administer in connexion with their duly authorized therapeutic functions; and

(ii) If the Parties deem these measures necessary or desirable, require that prescriptions for drugs in Schedule I should be written on official forms to be issued in the form of counterfoil books by the competent governmental authorities or by authorized professional associations.

3. It is desirable that Parties require that written or printed offers of drugs, advertisements of every kind or descriptive literature relating to drugs and used for commercial purposes, interior wrappings of packages containing drugs, and labels under which drugs are offered for sale indicate the international nonproprietary name communicated by the World Health Organization.

4. If a Party considers such measure necessary or desirable, it shall require that the inner package containing a drug or wrapping thereof shall bear a clearly visible double red band. The exterior wrapping of the package in which such drug is contained shall not bear a double red band.

5. A Party shall require that the label under which a drug is offered for sale show the exact drug content by weight or percentage. This requirement of label information need not apply to a drug dispensed to an individual on medical prescription.

6. The provisions of paragraphs 2 and 5 need not apply to the retail trade in or retail distribution of drugs in Schedule II. 


\section{Article 31. Special provisions relating to international trade}

1. The Parties shall not knowingly permit the export of drugs to any country or territory except:

(a) In accordance with the laws and regulations of that country or territory; and

(b) Within the limits of the total of the estimates for that country or territory, as defined in paragraph 2 of article 19, with the addition of the amounts intended to be re-exported.

2. The Parties shall exercise in free ports and zones the same supervision and control as in other parts of their territories, provided, however, that they may apply more drastic measures.

3. The Parties shall:

(a) Control under licence the import and export of drugs except where such import or export is carried out by a State enterprise or enterprises;

(b) Control all persons and enterprises carrying on or engaged in such import or export.

4. (a) Every Party permitting the import or export of drugs shall require a separate import or export authorization to be obtained for each such import or export whether it consists of one or more drugs.

(b) Such authorization shall state the name of the drug, the international non-proprietary name if any, the quantity to be imported or exported, and the name and address of the importer and exporter, and shall specify the period within which the importation or exportation must be effected.

(c) The export authorization shall also state the number and date of the import certificate (paragraph 5) and the authority by whom it has been issued.

(d) The import authorization may allow an importation in more than one consignment.

5. Before issuing an export authorization the Parties shall require an import certificate, issued by the competent authorities of the importing country 
or territory and certifying that the importation of the drug or drugs referred to therein, is approved and such certificate shall be produced by the person or establishment applying for the export authorization. The Parties shall follow as closely as may be practicable the form of import certificate approved by the Commission.

6. A copy of the export authorization shall accompany each consignment, and the Government issuing the export authorization shall send a copy to the Government of the importing country or territory.

7. (a) The Government of the importing country or territory, when the importation has been effected or when the period fixed for the importation has expired, shall return the export authorization, with an endorsement to that effect, to the Government of the exporting country or territory.

(b) The endorsement shall specify the amount actually imported;

(c) If a lesser quantity than that specified in the export authorization is actually exported, the quantity actually exported shall be stated by the competent authorities on the export authorization and on any official copy thereof.

8. Exports of consignments to a post office box, or to a bank to the account of a Party other than the Party named in the export authorization, shall be prohibited.

9. Exports of consignments to a bonded warehouse are prohibited unless the Government of the importing country certifies on the import certificate, produced by the person or establishment applying for the export authorization, that it has approved the importation for the purpose of being placed in a bonded warehouse. In such case the export authorization shall specify that the consignment is exported for such purpose. Each withdrawal from the bonded warehouse shall require a permit from the authorities having jurisdiction over the warehouse and, in the case of a foreign destination shall be treated as if it were a new export within the meaning of this Convention.

10. Consignments of drugs entering or leaving the territory of a Party not accompanied by an export authorization shall be detained by the competent authorities.

11. A Party shall not permit any drugs consigned to another country to pass through its territory, whether or not the consignment is removed from the 
conveyance in which it is carried, unless a copy of the export authorization for such consignment is produced to the competent authorities of such Party.

12. The competent authorities of any country or territory through which a consignment of drugs is permitted to pass shall take all due measures to prevent the diversion of the consignment to a destination other than that named in the accompanying copy of the export authorization unless the Government of that country or territory through which the consignment is passing authorizes the diversion. The Government of the country or territory of transit shall treat any requested diversion as if the diversion were an export from the country or territory of transit to the country or territory of new destination. If the diversion is authorized, the provisions of paragraph 7 (a) and (b) shall also apply between the country or territory of transit and the country or territory which originally exported the consignment.

13. No consignment of drugs while in transit, or whilst being stored in a bonded warehouse, may be subjected to any process which would change the nature of the drugs in question. The packing may not be altered without the permission of the competent authorities.

14. The provisions of paragraphs 11 to 13 relating to the passage of drugs through the territory of a Party do not apply where the consignment in question is transported by aircraft which does not land in the country or territory of transit. If the aircraft lands in any such country or territory, those provisions shall be applied so far as circumstances require.

15. The provisions of this article are without prejudice to the provisions of any international agreements which limit the control which may be exercised by any of the Parties over drugs in transit.

16. Nothing in this article other than paragraphs 1 (a) and 2 need apply in the case of preparations in Schedule III.

Article 32. Special provisions concerning the carriage of drugs in first-aid kits of ships or aircraft engaged in international traffic

1. The international carriage by ships or aircraft of such limited amounts of drugs as may be needed during their journey or voyage for first-aid purposes 
or emergency cases shall not be considered to be import, export or passage through a country within the meaning of this Convention.

2. Appropriate safeguards shall be taken by the country of registry to prevent the improper use of the drugs referred to in paragraph 1 or their diversion for illicit purposes. The Commission, in consultation with the appropriate international organizations, shall recommend such safeguards.

3. Drugs carried by ships or aircraft in accordance with paragraph 1 shall be subject to the laws, regulations, permits and licences of the country of registry, without prejudice to any rights of the competent local authorities to carry out checks, inspections and other control measures on board ships or aircraft. The administration of such drugs in the case of emergency shall not be considered a violation of the requirements of article 30, paragraph 2 (b).

\section{Article 33. Possession of drugs}

The Parties shall not permit the possession of drugs except under legal authority.

\section{Article 34. Measures of supervision and inspection}

The Parties shall require:

(a) That all persons who obtain licences as provided in accordance with this Convention, or who have managerial or supervisory positions in a State enterprise established in accordance with this Convention, shall have adequate qualifications for the effective and faithful execution of the provisions of such laws and regulations as are enacted in pursuance thereof; and

(b) That governmental authorities, manufacturers, traders, scientists, scientific institutions and hospitals keep such records as will show the quantities of each drug manufactured and of each individual acquisition and disposal of drugs. Such records shall respectively be preserved for a period of not less than two years. Where counterfoil books (article 30, paragraph 2 (b)) of official prescriptions are used, such books including the counterfoils shall also be kept for a period of not less than two years. 


\section{Article 35. Action against the illicit traffic}

Having due regard to their constitutional, legal and administrative systems, the Parties shall:

(a) Make arrangements at the national level for co-ordination of preventive and repressive action against the illicit traffic; to this end they may usefully designate an appropriate agency responsible for such co-ordination;

(b) Assist each other in the campaign against the illicit traffic in narcotic drugs;

(c) Co-operate closely with each other and with the competent international organizations of which they are members with a view to maintaining a co-ordinated campaign against the illicit traffic;

(d) Ensure that international co-operation between the appropriate agencies be conducted in an expeditious manner; and

(e) Ensure that where legal papers are transmitted internationally for the purposes of a prosecution, the transmittal be effected in an expeditious manner to the bodies designated by the Parties; this requirement shall be without prejudice to the right of a Party to require that legal papers be sent to it through the diplomatic channel;

(f) Furnish, if they deem it appropriate, to the Board and the Commission through the Secretary-General, in addition to information required by article 18 , information relating to illicit drug activity within their borders, including information on illicit cultivation, production, manufacture and use of, and on illicit trafficking in, drugs; and

(g) Furnish the information referred to in the preceding paragraph as far as possible in such manner and by such dates as the Board may request; if requested by a Party, the Board may offer its advice to it in furnishing the information and in endeavouring to reduce the illicit drug activity within the borders of that Party.

\section{Article 36. Penal provisions}

1. (a) Subject to its constitutional limitations, each Party shall adopt such measures as will ensure that cultivation, production, manufacture, 
extraction, preparation, possession, offering, offering for sale, distribution, purchase, sale, delivery on any terms whatsoever, brokerage, dispatch, dispatch in transit, transport, importation and exportation of drugs contrary to the provisions of this Convention, and any other action which in the opinion of such Party may be contrary to the provisions of this Convention, shall be punishable offences when committed intentionally, and that serious offences shall be liable to adequate punishment particularly by imprisonment or other penalties of deprivation of liberty.

(b) Notwithstanding the preceding subparagraph, when abusers of drugs have committed such offences, the Parties may provide, either as an alternative to conviction or punishment or in addition to conviction or punishment, that such abusers shall undergo measures of treatment, education, after-care, rehabilitation and social reintegration in conformity with paragraph 1 of article 38 .

2. Subject to the constitutional limitations of a Party, its legal system and domestic law,

(a) (i) Each of the offences enumerated in paragraph 1, if committed in different countries, shall be considered as a distinct offence;

(ii) Intentional participation in, conspiracy to commit and attempts to commit, any of such offences, and preparatory acts and financial operations in connexion with the offences referred to in this article, shall be punishable offences as provided in paragraph 1 ;

(iii) Foreign convictions for such offences shall be taken into account for the purpose of establishing recidivism; and

(iv) Serious offences heretofore referred to committed either by nationals or by foreigners shall be prosecuted by the Party in whose territory the offence was committed, or by the Party in whose territory the offender is found if extradition is not acceptable in conformity with the law of the Party to which application is made, and if such offender has not already been prosecuted and judgement given.

(b) (i) Each of the offences enumerated in paragraphs 1 and 2 (a) (ii) of this article shall be deemed to be included as an extraditable offence in any extradition treaty existing between Parties. Parties 
undertake to include such offences as extraditable offences in every extradition treaty to be concluded between them;

(ii) If a Party which makes extradition conditional on the existence of a treaty receives a request for extradition from another Party with which it has no extradition treaty, it may at its option consider this Convention as the legal basis for extradition in respect of the offences enumerated in paragraphs 1 and 2 (a) (ii) of this article. Extradition shall be subject to the other conditions provided by the law of the requested Party;

(iii) Parties which do not make extradition conditional on the existence of a treaty shall recognize the offences enumerated in paragraphs 1 and 2 (a) (ii) of this article as extraditable offences between themselves, subject to the conditions provided by the law of the requested Party;

(iv) Extradition shall be granted in conformity with the law of the Party to which application is made, and, notwithstanding subparagraphs (b) (i), (ii) and (iii) of this paragraph, the Party shall have the right to refuse to grant the extradition in cases where the competent authorities consider that the offence is not sufficiently serious.

3. The provisions of this article shall be subject to the provisions of the criminal law of the Party concerned on questions of jurisdiction.

4. Nothing contained in this article shall affect the principle that the offences to which it refers shall be defined, prosecuted and punished in conformity with the domestic law of a Party.

\section{Article 37. Seizure and confiscation}

Any drugs, substances and equipment used in or intended for the commission of any of the offences, referred to in article 36 , shall be liable to seizure and confiscation. 


\section{Article 38. Measures against the abuse of drugs}

1. The Parties shall give special attention to and take all practicable measures for the prevention of abuse of drugs and for the early identification, treatment, education, after-care, rehabilitation and social reintegration of the persons involved and shall co-ordinate their efforts to these ends.

2. The Parties shall as far as possible promote the training of personnel in the treatment, after-care, rehabilitation and social reintegration of abusers of drugs.

3. The Parties shall take all practicable measures to assist persons whose work so requires to gain an understanding of the problems of abuse of drugs and of its prevention, and shall also promote such understanding among the general public if there is a risk that abuse of drugs will become widespread.

\section{Article 38 bis. Agreements on regional centres}

If a Party considers it desirable as part of its action against the illicit traffic in drugs, having due regard to its constitutional, legal and administrative systems, and, if it so desires, with the technical advice of the Board or the specialized agencies, it shall promote the establishment, in consultation with other interested Parties in the region, of agreements which contemplate the development of regional centres for scientific research and education to combat the problems resulting from the illicit use of and traffic in drugs.

\section{Article 39. Application of stricter national control measures than those required by this Convention}

Notwithstanding anything contained in this Convention, a Party shall not be, or be deemed to be, precluded from adopting measures of control more strict or severe than those provided by this Convention and in particular from requiring that preparations in Schedule III or drugs in Schedule II be subject to all or such of the measures of control applicable to drugs in Schedule I as in its opinion is necessary or desirable for the protection of the public health or welfare. 


\section{Article 40. ${ }^{3}$ Languages of the Convention and procedure for signature, ratification and accession}

1. This Convention, of which the Chinese, English, French, Russian and Spanish texts are equally authentic, shall be open for signature until 1 August 1961 on behalf of any Member of the United Nations, of any non-member State which is a Party to the Statute of the International Court of Justice or member of a specialized agency of the United Nations, and also of any other State which the Council may invite to become a Party.

2. This Convention is subject to ratification. The instruments of ratification shall be deposited with the Secretary-General.

3. This Convention shall be open after 1 August 1961 for accession by the States referred to in paragraph 1 . The instruments of accession shall be deposited with the Secretary-General.

\section{Article 41.4 Entry into force}

1. This Convention shall come into force on the thirtieth day following the date on which the fortieth instrument of ratification or accession is deposited in accordance with article 40 .

2. In respect of any other State depositing an instrument of ratification or accession after the date of deposit of the said fortieth instrument, this Convention shall come into force on the thirtieth day after the deposit by that State of its instrument of ratification or accession.

${ }^{3}$ Note by the Secretariat: The following two paragraphs are taken from the Introductory Note to the text of the Single Convention on Narcotic Drugs, 1961, as amended by the Protocol Amending the Single Convention on Narcotic Drugs, 1961, as established by the Secretary-General on 8 August 1975, in accordance with article 22 of the Protocol of 25 March 1972:

"The Protocol Amending the Single Convention on Narcotic Drugs, 1961 (hereinafter called the 1972 Protocol) entered into force on 8 August 1975, in accordance with paragraph 1 of its article 18. In respect to any States which is already a Party to the Single Convention and deposits with the Secretary-General, after the date of deposit of the fortieth instrument of ratification or accession, an instrument of ratification or accession to the 1972 Protocol, the latter will come into force on the thirtieth day after the deposit by that State of its instrument (see articles 17 and 18 of the 1972 Protocol).

"Any State which becomes a Party to the Single Convention after the entry into force of the 1972 Protocol shall, failing an expression of a different intention by that State: (a) be considered as a Party to the Single Convention as amended; and (b) be considered as a Party to the unamended Single Convention in relation to any Party to that Convention not bound by the 1972 Protocol (see article 19 of the 1972 Protocol)."

${ }^{4}$ See footnote 3 above. 


\section{Article 42. Territorial application}

This Convention shall apply to all non-metropolitan territories for the international relations of which any Party is responsible, except where the previous consent of such a territory is required by the Constitution of the Party or of the territory concerned, or required by custom. In such case the Party shall endeavour to secure the needed consent of the territory within the shortest period possible, and when that consent is obtained the Party shall notify the Secretary-General. This Convention shall apply to the territory or territories named in such notification from the date of its receipt by the Secretary-General. In those cases where the previous consent of the non-metropolitan territory is not required, the Party concerned shall, at the time of signature, ratification or accession, declare the non-metropolitan territory or territories to which this Convention applies.

\section{Article 43. Territories for the purposes of articles 19, 20, 21 and 31}

1. Any Party may notify the Secretary-General that, for the purposes of articles 19, 20, 21 and 31, one of its territories is divided into two or more territories, or that two or more of its territories are consolidated into a single territory.

2. Two or more Parties may notify the Secretary-General that, as the result of the establishment of a customs union between them, those Parties constitute a single territory for the purposes of articles 19, 20, 21 and 31.

3. Any notification under paragraph 1 or 2 above shall take effect on 1 January of the year following the year in which the notification was made.

Article 44. Termination of previous international treaties

1. The provisions of this Convention, upon its coming into force, shall, as between Parties hereto, terminate and replace the provisions of the following treaties: 
(a) International Opium Convention, signed at The Hague on 23 January 1912;

(b) Agreement concerning the Manufacture of, Internal Trade in and Use of Prepared Opium, signed at Geneva on 11 February 1925;

(c) International Opium Convention, signed at Geneva on 19 February 1925 ;

(d) Convention for Limiting the Manufacture and Regulating the Distribution of Narcotic Drugs, signed at Geneva on 13 July 1931;

(e) Agreement for the Control of Opium Smoking in the Far East, signed at Bangkok on 27 November 1931;

(f) Protocol signed at Lake Success on 11 December 1946, amending the Agreements, Conventions and Protocols on Narcotic Drugs concluded at The Hague on 23 January 1912, at Geneva on 11 February 1925 and 19 February 1925 and 13 July 1931, at Bangkok on 27 November 1931 and at Geneva on 26 June 1936, except as it affects the last-named Convention;

(g) The Conventions and Agreements referred to in subparagraphs (a) to (e) as amended by the Protocol of 1946 referred to in subparagraph $(f)$;

(b) Protocol signed at Paris on 19 November 1948 bringing under international control drugs outside the scope of the Convention of 13 July 1931 for Limiting the Manufacture and Regulating the Distribution of Narcotic Drugs, as Amended by the Protocol signed at Lake Success on 11 December 1946;

(i) Protocol for Limiting and Regulating the Cultivation of the Poppy Plant, the Production of, International and Wholesale Trade in, and Use of Opium, signed at New York on 23 June 1953, should that Protocol have come into force.

2. Upon the coming into force of this Convention, article 9 of the Convention for the Suppression of the Illicit Traffic in Dangerous Drugs, signed at Geneva on 26 June 1936, shall, between the Parties thereto which are also Parties to this Convention, be terminated, and shall be replaced by paragraph 2 (b) of article 36 of this Convention; provided that such a Party may by notification to the Secretary-General continue in force the said article 9. 


\section{Article 45. ${ }^{5}$ Transitional provisions}

1. The functions of the Board provided for in article 9 shall, as from the date of the coming into force of this Convention (article 41, paragraph 1), be provisionally carried out by the Permanent Central Board constituted under chapter VI of the Convention referred to in article 44 (c) as amended, and by the Supervisory Body constituted under chapter II of the Convention referred to in article $44(d)$ as amended, as such functions may respectively require.

2. The Council shall fix the date on which the new Board referred to in article 9 shall enter upon its duties. As from that date that Board shall, with respect to the States Parties to the treaties enumerated in article 44 which are not Parties to this Convention, undertake the functions of the Permanent Central Board and of the Supervisory Body referred to in paragraph 1.

\section{Article 46. Denunciation}

1. After the expiry of two years from the date of the coming into force of this Convention (article 41, paragraph 1) any Party may, on its own behalf or on behalf of a territory for which it has international responsibility, and which has withdrawn its consent given in accordance with article 42, denounce this Convention by an instrument in writing deposited with the Secretary-General.

2. The denunciation, if received by the Secretary-General on or before the first day of July in any year, shall take effect on the first day of January in the

${ }^{5}$ The following is the text of article 20 of the 1972 Protocol:

\section{"Article 20 \\ "Transitional provisions}

"1. The functions of the International Narcotics Control Board provided for in the amendments contained in this Protocol shall, as from the date of coming into force of this Protocol pursuant to paragraph 1 of article 18 above, be performed by the Board as constituted by the unamended Single Convention.

"2. The Economic and Social Council shall fix the date on which the Board constituted under the amendments contained in this Protocol shall enter upon its duties. As from that date the Board as so constituted shall, with respect to those Parties to the unamended Single Convention and to those Parties to the treaties enumerated in article 44 thereof which are not Parties to this Protocol, undertake the functions of the Board as constituted under the unamended Single Convention.

"3. Of the members elected at the first election after the increase in the membership of the Board from eleven to thirteen members the terms of six members shall expire at the end of three years and the terms of the other seven members shall expire at the end of five years.

"4. The members of the Board whose terms are to expire at the end of the above-mentioned initial period of three years shall be chosen by lot to be drawn by the Secretary-General immediately after the first election has been completed." 
succeeding year, and, if received after the first day of July, shall take effect as if it had been received on or before the first day of July in the succeeding year.

3. This Convention shall be terminated if, as a result of denunciations made in accordance with paragraph 1 , the conditions for its coming into force as laid down in article 41, paragraph 1 , cease to exist.

\section{Article 47. Amendments}

1. Any Party may propose an amendment to this Convention. The text of any such amendment and the reasons therefor shall be communicated to the Secretary-General who shall communicate them to the Parties and to the Council. The Council may decide either:

(a) That a conference shall be called in accordance with Article 62, paragraph 4, of the Charter of the United Nations to consider the proposed amendment; or

(b) That the Parties shall be asked whether they accept the proposed amendment and also asked to submit to the Council any comments on the proposal.

2. If a proposed amendment circulated under paragraph 1 (b) of this article has not been rejected by any Party within eighteen months after it has been circulated, it shall thereupon enter into force. If, however, a proposed amendment is rejected by any Party, the Council may decide, in the light of comments received from Parties, whether a conference shall be called to consider such amendment.

\section{Article 48. Disputes}

1. If there should arise between two or more Parties a dispute relating to the interpretation or application of this Convention, the said Parties shall consult together with a view to the settlement of the dispute by negotiation, investigation, mediation, conciliation, arbitration, recourse to regional bodies, judicial process or other peaceful means of their own choice.

2. Any such dispute which cannot be settled in the manner prescribed shall be referred to the International Court of Justice for decision. 


\section{Article 49. Transitional reservations}

1. A Party may at the time of signature, ratification or accession reserve the right to permit temporarily in any one of its territories:

(a) The quasi-medical use of opium;

(b) Opium smoking;

(c) Coca leaf chewing;

(d) The use of cannabis, cannabis resin, extracts and tinctures of cannabis for non-medical purposes; and

(e) The production and manufacture of and trade in the drugs referred to under (a) to (d) for the purposes mentioned therein.

2. The reservations under paragraph 1 shall be subject to the following restrictions:

(a) The activities mentioned in paragraph 1 may be authorized only to the extent that they were traditional in the territories in respect of which the reservation is made, and were there permitted on 1 January 1961;

(b) No export of the drugs referred to in paragraph 1 for the purposes mentioned therein may be permitted to a non-party or to a territory to which this Convention does not apply under article 42;

(c) Only such persons may be permitted to smoke opium as were registered by the competent authorities to this effect on 1 January 1964;

(d) The quasi-medical use of opium must be abolished within 15 years from the coming into force of this Convention as provided in paragraph 1 of article 41;

(e) Coca leaf chewing must be abolished within twenty-five years from the coming into force of this Convention as provided in paragraph 1 of article 41;

(f) The use of cannabis for other than medical and scientific purposes must be discontinued as soon as possible but in any case within twenty-five years 
from the coming into force of this Convention as provided in paragraph 1 of article 41;

(g) The production and manufacture of and trade in the drugs referred to in paragraph 1 for any of the uses mentioned therein must be reduced and finally abolished simultaneously with the reduction and abolition of such uses.

3. A Party making a reservation under paragraph 1 shall:

(a) Include in the annual report to be furnished to the Secretary-General, in accordance with article 18, paragraph $1(a)$, an account of the progress made in the preceding year towards the abolition of the use, production, manufacture or trade referred to under paragraph 1 ; and

(b) Furnish to the Board separate estimates (article 19) and statistical returns (article 20) in respect of the reserved activities in the manner and form prescribed by the Board.

4. (a) If a Party which makes a reservation under paragraph 1 fails to furnish:

(i) The report referred to in paragraph 3 (a) within six months after the end of the year to which the information relates;

(ii) The estimates referred to in paragraph 3 (b) within three months after the date fixed for that purpose by the Board in accordance with article 12, paragraph 1 ;

(iii) The statistics referred to in paragraph 3 (b) within three months after the date on which they are due in accordance with article 20 , paragraph 2,

the Board or the Secretary-General, as the case may be, shall send to the Party concerned a notification of the delay, and shall request such information within a period of three months after the receipt of that notification.

(b) If the Party fails to comply within this period with the request of the Board or the Secretary-General, the reservation in question made under paragraph 1 shall cease to be effective.

5. A State which has made reservations may at any time by notification in writing withdraw all or part of its reservations. 


\section{Article $50 .^{6}$ Other reservations}

1. No reservations other than those made in accordance with article 49 or with the following paragraphs shall be permitted.

2. Any State may at the time of signature, ratification or accession make reservations in respect of the following provisions of this Convention:

Article 12, paragraphs 2 and 3; article 13, paragraph 2; article 14, paragraphs 1 and 2; article 31, paragraph 1 (b), and article 48 .

3. A State which desires to become a Party but wishes to be authorized to make reservations other than those made in accordance with paragraph 2 of this article or with article 49 may inform the Secretary-General of such intention. Unless by the end of twelve months after the date of the Secretary-General's communication of the reservation concerned, this reservation has been objected to by one third of the States that have ratified or acceded to this Convention before the end of that period, it shall be deemed to be permitted, it being understood, however, that States which have objected to the reservation need not assume towards the reserving State any legal obligation under this Convention which is affected by the reservation.

4. A State which has made reservations may at any time by notification in writing withdraw all or part of its reservations.

\footnotetext{
${ }^{6}$ The following is the text of article 21 of the 1972 Protocol:

"Article 21

"Reservations

"1. Any State may, at the time of signature or ratification of or accession to this Protocol, make a reservation in respect of any amendment contained herein other than the amendments to article 2, paragraphs 6 and 7 (article 1 of this Protocol), article 9, paragraphs 1, 4 and 5 (article 2 of this Protocol), article 10, paragraphs 1 and 4 (article 3 of this Protocol), article 11 (article 4 of this Protocol), article 14 bis (article 7 of this Protocol), article 16 (article 8 of this Protocol), article 22 (article 12 of this Protocol), article 35 (article 13 of this Protocol), article 36, paragraph 1 (b) (article 14 of this Protocol), article 38 (article 15 of this Protocol) and article 38 bis (article 16 of this Protocol).*

"2. A State which has made reservations may at any time by notification in writing withdraw all or part of its reservations."

"Note by the Secretariat: The following explanatory note is reproduced from the certified true copy, established by the Secretary-General on 8 August 1975, of the Single Convention on Narcotic Drugs, 1961, as amended by the 1972 Protocol Amending the Single Convention on Narcotic Drugs, 1961:

"It will be noted that States that wish to make a reservation to one or more of the amendments in accordance with the above article 21 of the 1972 Protocol should first become Parties to the Single Convention in its unamended form (if they have not already done so), and then should ratify or accede to the 1972 Protocol subject to the desired reservation.”
} 


\section{Article 51. Notifications}

The Secretary-General shall notify to all the States referred to in paragraph 1 of article 40:

(a) Signatures, ratifications and accessions in accordance with article 40;

(b) The date upon which this Convention enters into force in accordance with article 41;

(c) Denunciations in accordance with article 46; and

(d) Declarations and notifications under articles 42, 43, 47, 49 and 50.

Note: The revised list of drugs in Schedules I, II, III and IV of the Single Convention on Narcotic Drugs of 1961 as amended by the 1972 Protocol is contained in ST/CND/1/Add.1. 
Part Two

\section{CONVENTION ON PSYCHOTROPIC SUBSTANCES OF 1971}

including Final Act and Resolutions, as agreed by the 1971 United Nations

Conference for the Adoption of a Protocol on Psychotropic Substances 



\section{Contents}

United Nations Conference for the Adoption of a Protocol on Psychotropic Substances ............................................................................ 71

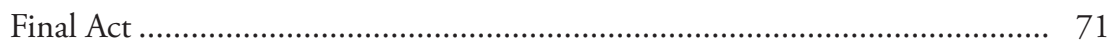

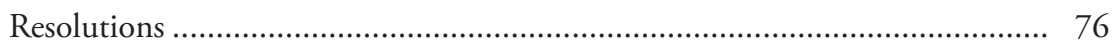

Convention on Psychotropic Substances ..................................................... 78

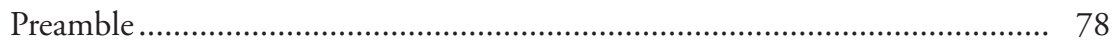

Article 1. Use of terms ................................................................... 79

Article 2. Scope of control of substances ….......................................... 80

Article 3. Special provisions regarding the control of preparations.............. 84

Article 4. Other special provisions regarding the scope of control.............. 86

Article 5. Limitation of use to medical and scientific purposes .................. 86

Article 6. Special administration ...................................................... 87

Article 7. Special provisions regarding substances in Schedule I................ 87

Article 8. Licences........................................................................... 88

Article 9. Prescriptions ................................................................... 88

Article 10. Warnings on packaging and advertising .................................. 89

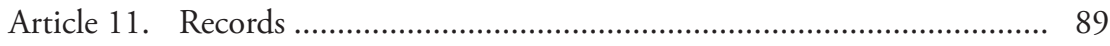

Article 12. Provisions relating to international trade................................... 90

Article 13. Prohibition of and restrictions on export and import................. 93

Article 14. Special provisions concerning the carriage of psychotropic substances in first-aid kits of ships, aircraft or other forms of public transport engaged in international traffic ........................ 94

Article 15. Inspection............................................................................ 94 
Article 16. Reports to be furnished by the Parties

Article 17. Functions of the Commission

Article 18. Reports of the Board

Article 19. Measures by the Board to ensure the execution of the provisions of the Convention

Article 20. Measures against the abuse of psychotropic substances............... 98

Article 21. Action against the illicit traffic ................................................. 99

Article 22. Penal provisions .................................................................. 99

Article 23. Application of stricter control measures than those required by this Convention

Article 24. Expenses of international organs incurred in administering the provisions of the Convention.

Article 25. Procedure for admission, signature, ratification and accession ..... 101

Article 26. Entry into force .................................................................... 102

Article 27. Territorial application ............................................................ 102

Article 28. Regions for the purposes of this Convention.............................. 103

Article 29. Denunciation ......................................................................... 103

Article 30. Amendments ........................................................................... 104

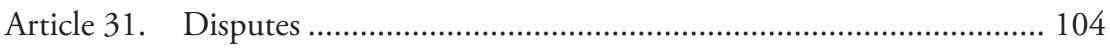

Article 32. Reservations............................................................................ 104

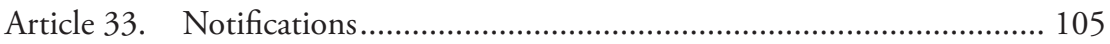




\section{Final Act of the United Nations Conference for the Adoption of a Protocol on Psychotropic Substances}

1. The Economic and Social Council of the United Nations, in accordance with Article 62, paragraph 4, of the Charter of the United Nations, and with the provisions of General Assembly resolution 366 (IV) of 3 December 1949, decided, by resolution 1474 (XLVIII), to convene a conference of plenipotentiaries for the adoption of a protocol on psychotropic substances.

2. The United Nations Conference for the Adoption of a Protocol on Psychotropic Substances met in Vienna from 11 January to 21 February 1971.

3. The following seventy-one States were represented by representatives at the Conference:

$\begin{array}{lll}\text { Algeria } & \text { Colombia } & \text { Greece } \\ \text { Argentina } & \text { Congo (Democratic } & \text { Guatemala } \\ \text { Australia } & \text { Republic of) } & \text { Guyana } \\ \text { Austria } & \text { Costa Rica } & \text { Holy See } \\ \text { Belgium } & \text { Denmark } & \text { Honduras } \\ \text { Brazil } & \text { Dominican Rep. } & \text { Hungary } \\ \text { Bulgaria } & \text { Ecuador } & \text { India } \\ \text { Burma } & \text { El Salvador } & \text { Iran } \\ \text { Byelorussian Soviet } & \text { Federal Republic of } & \text { Iraq } \\ \text { Socialist Republic } & \text { Germany } & \text { Ireland } \\ \text { Cameroon } & \text { Finland } & \text { Israel } \\ \text { Canada } & \text { France } & \text { Italy } \\ \text { Chile } & \text { Gabon } & \text { Japan } \\ \text { China } & \text { Ghana } & \text { Lebanon }\end{array}$




\begin{tabular}{lll} 
Liberia & Portugal & Turkey \\
Luxembourg & Republic of Korea & Ukrainian Soviet \\
Mexico & Rwanda & Socialist Republic \\
Monaco & San Marino & Union of Soviet \\
Socialist Republics \\
Netherlands & South Africa & United Arab Republic \\
New Zealand & Spain & United Kingdom of \\
Nicaragua & Sweden & Great Britain and \\
Norway & Switzerland & Northern Ireland \\
Pakistan & Thailand & United States of \\
Panama & Togo & America \\
Paraguay & Trinidad and Tobago & Venezuela \\
Poland & Tunisia & Yugoslavia \\
\multicolumn{1}{c}{ 4. The following } & States were represented at & the Conference by an \\
observer: & & \\
Czechoslovakia & Romania & \\
Republic of Viet-Nam & Uruguay
\end{tabular}

5. The following specialized agency was represented at the Conference: World Health Organization

6. The following international body was represented at the Conference: International Narcotics Control Board

7. The following non-governmental organization was represented at the Conference by invitation, in accordance with Economic and Social Council resolution 1474 (XLVIII):

International Criminal Police Organization (ICPO/INTERPOL)

8. General A. A. El Hadeka, Director of the Permanent Anti-Narcotics Bureau of the League of Arab States, at the invitation at the Conference, also attended in a personal capacity under rule 39 of the rules of procedure.

9. In accordance with the resolution of the Economic and Social Council referred to in paragraph 1 , and with the rules of procedure adopted by the 
Conference, the observers and the representatives of the above-mentioned organizations and bodies participated in the work of the Conference without the right to vote.

10. The Conference elected Mr. E. Nettel (Austria) as President, and as Vice-Presidents the representatives of the following States:

$\begin{array}{llr}\text { Brazil } & \text { Togo } & \text { United Kingdom of } \\ \text { Ghana } & \text { Turkey } & \text { Great Britain and } \\ \text { India } & \text { Union of Soviet } & \text { Northern Ireland } \\ \text { Japan } & \text { Socialist Republics } & \text { United States of } \\ \text { Mexico } & \text { United Arab Republic } & \text { America }\end{array}$

11. Mr. V. Winspeare-Guicciardi acted as the representative of the Secretary-General on the opening day of the Conference, being succeeded thereafter by Dr. V. Kušević. The Executive Secretary of the Conference was Dr. V. Kušević, the Legal Adviser was Mr. G. Wattles and the Deputy Executive Secretary was Mr. Ansar Khan.

12. The Conference had before it a draft protocol on psychotropic substances prepared by the Commission on Narcotic Drugs of the Council, and other documentation prepared by the Secretary-General.

13. The Conference set up the following Committees:

General Committee

Chairman: The President of the Conference

Technical Committee

Chairman: Professor B. A. Rexed (Sweden)

Drafting Committee

Chairman: Mr. D. Nikolić (Yugoslavia)

Committee on Control Measures

Chairman: Dr. J. Mabileau (France) 


\section{Credentials Committee}

Chairman: Dr. P. A. Jennings (Ireland)

14. The Technical Committee established the following ad hoc Working Group:

Ad hoc Working Group on article 2 (paragraphs 4 and 5) (Scope of control of substances)

Chairman: Dr. H. El Hakim (United Arab Republic)

15. The Committee on Control Measures established the following ad hoc working groups:

Ad hoc Working Group on article 2 (Scope of control of substances)

Chairman: Mr. D. P. Anand (India)

Ad hoc Working Group on article 2 (Special provisions regarding the control of preparations)

Chairman: Mr. D. E. Miller (United States of America)

Ad hoc Working Group on article 4 (Limitation of use to medical and scientific purposes)

Chairman: Dr. A. M. Walshe (Australia)

Ad hoc Working Group on article 6 (Special provisions regarding substances in Schedule I)

Chairman: Mr. J. H. W. Hoogwater (Netherlands)

Ad hoc Working Group on article 7 (Licences)

Chairman: Mr. D. Nikolić (Yugoslavia)

Ad hoc Working Group on article 8 (Prescriptions)

Chairman: Dr. V. V. Olguin (Argentina)

Ad hoc Working Group on article 10 (Records)

Chairman: Mr. A. C. Kirca 
Ad hoc Working Group on articles 11 and 12 (Provisions relating to international trade and Prohibition of and restriction on the import and export of psychotropic substances)

Chairman: Mr. J. P. Bertschinger (Switzerland)

Ad hoc Working Group on article 14 (Reports to be furnished by Parties) Chairman: Mr. M. K. B. Asante (Ghana)

16. As a result of its deliberations, as recorded in the summary records of the Plenary and the minutes of the meetings of the General Committee and the Committee on Control Measures and in the reports of all the Committees, the Conference adopted and opened for signature the Convention on Psychotropic Substances, 1971. In addition the Conference adopted three resolutions annexed to this Final Act.

DONE at Vienna, this twenty-first day of February, one thousand nine hundred and seventy-one, in a single copy in the Chinese, English, French, Russian and Spanish languages, each text being equally authentic. The original text shall be deposited with the Secretary-General of the United Nations.

IN WITNESS WHEREOF the representatives have signed this Final Act. 


\title{
Resolutions adopted by the United Nations Conference for the Adoption of a Protocol on Psychotropic Substances
}

\author{
Resolution I \\ Provisional application of the Convention on \\ Psychotropic Substances pending its entry into force
}

The Conference,

1. Invites States, to the extent that they are able to do so, to apply provisionally the measures of control provided in the Convention on Psychotropic Substances pending its entry into force for each of them;

2. Requests the Secretary-General to transmit this resolution to the Economic and Social Council, the General Assembly and the World Health Organization, with a view to their reaffirming the invitation contained herein.

\section{Resolution II \\ Research on the amphetamine drugs}

The Conference,

Considering that the amphetamines are particularly liable to abuse and are objects of illicit traffic,

Considering that the therapeutic value of these drugs, though acknowledged, is limited,

1. Requests the World Health Assembly to encourage research on less dangerous substances capable of replacing the amphetamine drugs, and to sponsor such research within the limits of the available resources;

2. Recommends that Governments with the necessary facilities should take similar action. 


\section{Resolution III}

Tribute to the Federal Government of the Republic of Austria

\section{The Conference,}

Being convened by resolution 1474 (XLVIII) of the Economic and Social Council of 24 March 1970,

Having met in Vienna from 11 January to 21 February 1971, at the invitation of the Government of the Republic of Austria,

Expresses to the Government of the Republic of Austria its deep appreciation for the facilities and courtesies extended to it by the Government, which contributed notably to the success of its work. 


\title{
Convention on Psychotropic Substances*
}

\author{
Preamble
}

The Parties,

Being concerned with the health and welfare of mankind,

Noting with concern the public health and social problems resulting from the abuse of certain psychotropic substances,

Determined to prevent and combat abuse of such substances and the illicit traffic to which it gives rise,

Considering that rigorous measures are necessary to restrict the use of such substances to legitimate purposes,

Recognizing that the use of psychotropic substances for medical and scientific purposes is indispensable and that their availability for such purposes should not be unduly restricted,

Believing that effective measures against abuse of such substances require co-ordination and universal action,

Acknowledging the competence of the United Nations in the field of control of psychotropic substances and desirous that the international organs concerned should be within the framework of that Organization,

Recognizing that an international convention is necessary to achieve these purposes,

Agree as follows:

\footnotetext{
* Note by the Secretariat: In the following text a number of minor corrections are included which were required owing to certain errors and omissions in the English text of the original of the Convention and which were made by a Procès-Verbal of Rectification of the Original of the Convention, signed on 15 August 1973 and communicated to Governments by the Office of Legal Affairs of the United Nations in circular notes C.N.169. 1973. TREATIES-5 and C.N.321. 1974. TREATIES-1 dated 30 August 1973 and 9 December 1974 respectively. They affect article 2, para. 7 (a) and the chemical formulae of certain substances in Schedules I, II and IV of the Convention.
} 


\section{Article 1. Use of terms}

Except where otherwise expressly indicated, or where the context otherwise requires, the following terms in this Convention have the meanings given below:

(a) "Council" means the Economic and Social Council of the United Nations.

(b) "Commission" means the Commission on Narcotic Drugs of the Council.

(c) "Board" means the International Narcotics Control Board provided for in the Single Convention on Narcotic Drugs, 1961.

(d) "Secretary-General" means the Secretary-General of the United Nations.

(e) "Psychotropic substance" means any substance, natural or synthetic, or any natural material in Schedule I, II, III or IV.

(f) "Preparation" means:

(i) Any solution or mixture, in whatever physical state, containing one or more psychotropic substances, or

(ii) One or more psychotropic substances in dosage form.

(g) "Schedule I", "Schedule II", "Schedule III" and "Schedule IV" mean the correspondingly numbered lists of psychotropic substances annexed to this Convention, as altered in accordance with article 2.

(b) "Export" and "import" mean in their respective connotations the physical transfer of a psychotropic substance from one State to another State.

(i) "Manufacture" means all processes by which psychotropic substances may be obtained, and includes refining as well as the transformation of psychotropic substances into other psychotropic substances. The term also includes the making of preparations other than those made on prescription in pharmacies.

(j) "Illicit traffic" means manufacture of or trafficking in psychotropic substances contrary to the provisions of this Convention.

(k) "Region" means any part of a State which pursuant to article 28 is treated as a separate entity for the purposes of this Convention. 
(l) "Premises" means buildings or parts of buildings, including the appertaining land.

\section{Article 2. Scope of control of substances}

1. If a Party or the World Health Organization has information relating to a substance not yet under international control which in its opinion may require the addition of that substance to any of the Schedules of this Convention, it shall notify the Secretary-General and furnish him with the information in support of that notification. The foregoing procedure shall also apply when a Party or the World Health Organization has information justifying the transfer of a substance from one Schedule to another among those Schedules, or the deletion of a substance from the Schedules.

2. The Secretary-General shall transmit such notification, and any information which he considers relevant, to the Parties, to the Commission and, when the notification is made by a Party, to the World Health Organization.

3. If the information transmitted with such a notification indicates that the substance is suitable for inclusion in Schedule I or Schedule II pursuant to paragraph 4, the Parties shall examine, in the light of all information available to them, the possibility of the provisional application to the substance of all measures of control applicable to substances in Schedule I or Schedule II, as appropriate.

4. If the World Health Organization finds:

(a) That the substance has the capacity to produce

(i) (1) A state of dependence, and

(2) Central nervous system stimulation or depression, resulting in hallucinations or disturbances in motor function or thinking or behaviour or perception or mood, or

(ii) Similar abuse and similar ill effects as a substance in Schedule I, II, III or IV, and

(b) That there is sufficient evidence that the substance is being or is likely to be abused so as to constitute a public health and social problem warranting the placing of the substance under international control, 
the World Health Organization shall communicate to the Commission an assessment of the substance, including the extent or likelihood of abuse, the degree of seriousness of the public health and social problem and the degree of usefulness of the substance in medical therapy, together with recommendations on control measures, if any, that would be appropriate in the light of its assessment.

5. The Commission, taking into account the communication from the World Health Organization, whose assessments shall be determinative as to medical and scientific matters, and bearing in mind the economic, social, legal, administrative and other factors it may consider relevant, may add the substance to Schedule I, II, III or IV. The Commission may seek further information from the World Health Organization or from other appropriate sources.

6. If a notification under paragraph 1 relates to a substance already listed in one of the Schedules, the World Health Organization shall communicate to the Commission its new findings, any new assessment of the substance it may make in accordance with paragraph 4 and any new recommendations on control measures it may find appropriate in the light of that assessment. The Commission, taking into account the communication from the World Health Organization as under paragraph 5 and bearing in mind the factors referred to in that paragraph, may decide to transfer the substance from one Schedule to another or to delete it from the Schedules.

7. Any decision of the Commission taken pursuant to this article shall be communicated by the Secretary-General to all States Members of the United Nations, to non-member States Parties to this Convention, to the World Health Organization and to the Board. Such decision shall become fully effective with respect to each Party 180 days after the date of such communication, except for any Party which, within that period, in respect of a decision adding a substance to a Schedule, has transmitted to the Secretary-General a written notice that, in view of exceptional circumstances, it is not in a position to give effect with respect to that substance to all of the provisions of the Convention applicable to substances in that Schedule. Such notice shall state the reasons for this exceptional action. Notwithstanding its notice, each Party shall apply, as a minimum, the control measures listed below:

(a) A Party having given such notice with respect to a previously uncontrolled substance added to Schedule I shall take into account, as far as possible, 
the special control measures enumerated in article 7 and, with respect to that substance, shall:

(i) Require licences for manufacture, trade and distribution as provided in article 8 for substances in Schedule II;

(ii) Require medical prescriptions for supply or dispensing as provided in article 9 for substances in Schedule II;

(iii) Comply with the obligations relating to export and import provided in article 12, except in respect to another Party having given such notice for the substance in question;

(iv) Comply with the obligations provided in article 13 for substances in Schedule II in regard to prohibition of and restrictions on export and import;

(v) Furnish statistical reports to the Board in accordance with paragraph 4 (a) of article 16; and

(vi) Adopt measures in accordance with article 22 for the repression of acts contrary to laws or regulations adopted pursuant to the foregoing obligations.

(b) A Party having given such notice with regard to a previously uncontrolled substance added to Schedule II shall, with respect to that substance:

(i) Require licences for manufacture, trade and distribution in accordance with article 8;

(ii) Require medical prescriptions for supply or dispensing in accordance with article 9;

(iii) Comply with the obligations relating to export and import provided in Article 12, except in respect to another Party having given such notice for the substance in question;

(iv) Comply with the obligations of article 13 in regard to prohibition of and restrictions on export and import;

(v) Furnish statistical reports to the Board in accordance with paragraphs $4(a),(c)$ and $(d)$ of article 16; and

(vi) Adopt measures in accordance with article 22 for the repression 
of acts contrary to laws or regulations adopted pursuant to the foregoing obligations.

(c) A Party having given such notice with regard to a previously uncontrolled substance added to Schedule III shall, with respect to that substance:

(i) Require licences for manufacture, trade and distribution in accordance with article 8;

(ii) Require medical prescriptions for supply or dispensing in accordance with article 9;

(iii) Comply with the obligations relating to export provided in article 12, except in respect to another Party having given such notice for the substance in question;

(iv) Comply with the obligations of article 13 in regard to prohibition of and restrictions on export and import; and

(v) Adopt measures in accordance with article 22 for the repression of acts contrary to laws or regulations adopted pursuant to the foregoing obligations.

(d) A Party having given such notice with regard to a previously uncontrolled substance added to Schedule IV shall, with respect to that substance:

(i) Require licences for manufacture, trade and distribution in accordance with article 8;

(ii) Comply with the obligations of article 13 in regard to prohibition of and restrictions on export and import; and

(iii) Adopt measures in accordance with article 22 for the repression of acts contrary to laws or regulations adopted pursuant to the foregoing obligations.

(e) A Party having given such notice with regard to a substance transferred to a Schedule providing stricter controls and obligations shall apply as a minimum all of the provisions of this Convention applicable to the Schedule from which it was transferred.

8. (a) The decisions of the Commission taken under this article shall be subject to review by the Council upon the request of any Party filed within 180 
days from receipt of notification of the decision. The request for review shall be sent to the Secretary-General together with all relevant information upon which the request for review is based.

(b) The Secretary-General shall transmit copies of the request for review and the relevant information to the Commission, to the World Health Organization and to all the Parties, inviting them to submit comments within ninety days. All comments received shall be submitted to the Council for consideration.

(c) The Council may confirm, alter or reverse the decision of the Commission. Notification of the Council's decision shall be transmitted to all States Members of the United Nations, to non-member States Parties to this Convention, to the Commission, to the World Health Organization and to the Board.

(d) During pendency of the review, the original decision of the Commission shall, subject to paragraph 7 , remain in effect.

9. The Parties shall use their best endeavours to apply to substances which do not fall under this Convention, but which may be used in the illicit manufacture of psychotropic substances, such measures of supervision as may be practicable.

\section{Article 3. Special provisions regarding the control of preparations}

1. Except as provided in the following paragraphs of this article, a preparation is subject to the same measures of control as the psychotropic substance which it contains, and, if it contains more than one such substance, to the measures applicable to the most strictly controlled of those substances.

2. If a preparation containing a psychotropic substance other than a substance in Schedule I is compounded in such a way that it presents no, or a negligible, risk of abuse and the substance cannot be recovered by readily applicable means in a quantity liable to abuse, so that the preparation does not give rise to a public health and social problem, the preparation may be exempted from certain of the measures of control provided in this Convention in accordance with paragraph 3 .

3. If a Party makes a finding under the preceding paragraph regarding a preparation, it may decide to exempt the preparation, in its country or in one of 
its regions, from any or all of the measures of control provided in this Convention except the requirements of:

(a) Article 8 (licences), as it applies to manufacture;

(b) Article 11 (records), as it applies to exempt preparations;

(c) Article 13 (prohibition of and restrictions on export and import);

(d) Article 15 (inspection), as it applies to manufacture;

(e) Article 16 (reports to be furnished by the Parties), as it applies to exempt preparations; and

(f) Article 22 (penal provisions), to the extent necessary for the repression of acts contrary to laws or regulations adopted pursuant to the foregoing obligations.

A Party shall notify the Secretary-General of any such decision, of the name and composition of the exempt preparation, and of the measures of control from which it is exempted. The Secretary-General shall transmit the notification to the other Parties, to the World Health Organization and to the Board.

4. If a Party or the World Health Organization has information regarding a preparation exempted pursuant to paragraph 3 which in its opinion may require the termination, in whole or in part, of the exemption, it shall notify the Secretary-General and furnish him with the information in support of the notification. The Secretary-General shall transmit such notification, and any information which he considers relevant, to the Parties, to the Commission and, when the notification is made by a Party, to the World Health Organization. The World Health Organization shall communicate to the Commission an assessment of the preparation in relation to the matters specified in paragraph 2 , together with a recommendation of the control measures, if any, from which the preparation should cease to be exempted. The Commission, taking into account the communication from the World Health Organization, whose assessment shall be determinative as to medical and scientific matters, and bearing in mind the economic, social, legal, administrative and other factors it may consider relevant, may decide to terminate the exemption of the preparation from any or all control measures. Any decision of the Commission taken pursuant to this paragraph shall be communicated by the Secretary-General to all States Members of the United Nations, to non-member States Parties to this Convention, to 
the World Health Organization and to the Board. All Parties shall take measures to terminate the exemption from the control measure or measures in question within 180 days of the date of the Secretary-General's communication.

\section{Article 4. Other special provisions regarding the scope of control}

In respect of psychotropic substances other than those in Schedule I, the Parties may permit:

(a) The carrying by international travellers of small quantities of preparations for personal use; each Party shall be entitled, however, to satisfy itself that these preparations have been lawfully obtained;

(b) The use of such substances in industry for the manufacture of nonpsychotropic substances or products, subject to the application of the measures of control required by this Convention until the psychotropic substances come to be in such a condition that they will not in practice be abused or recovered;

(c) The use of such substances, subject to the application of the measures of control required by this Convention, for the capture of animals by persons specifically authorized by the competent authorities to use such substances for that purpose.

\section{Article 5. Limitation of use to medical and scientific purposes}

1. Each Party shall limit the use of substances in Schedule I as provided in article 7.

2. Each Party shall, except as provided in article 4, limit by such measures as it considers appropriate the manufacture, export, import, distribution and stocks of, trade in, and use and possession of, substances in Schedules II, III and IV to medical and scientific purposes.

3. It is desirable that the Parties do not permit the possession of substances in Schedules II, III and IV except under legal authority. 


\section{Article 6. Special administration}

It is desirable that for the purpose of applying the provisions of this Convention, each Party establish and maintain a special administration, which may with advantage be the same as, or work in close co-operation with, the special administration established pursuant to the provisions of conventions for the control of narcotic drugs.

\section{Article 7. Special provisions regarding substances in Schedule I}

In respect of substances in Schedule I, the Parties shall:

(a) Prohibit all use except for scientific and very limited medical purposes by duly authorized persons, in medical or scientific establishments which are directly under the control of their Governments or specifically approved by them;

(b) Require that manufacture, trade, distribution and possession be under a special licence or prior authorization;

(c) Provide for close supervision of the activities and acts mentioned in paragraphs (a) and (b);

(d) Restrict the amount supplied to a duly authorized person to the quantity required for his authorized purpose;

(e) Require that persons performing medical or scientific functions keep records concerning the acquisition of the substances and the details of their use, such records to be preserved for at least two years after the last use recorded therein; and

(f) Prohibit export and import except when both the exporter and importer are the competent authorities or agencies of the exporting and importing country or region, respectively, or other persons or enterprises which are specifically authorized by the competent authorities of their country or region for the purpose. The requirements of paragraph 1 of article 12 for export and import authorizations for substances in Schedule II shall also apply to substances in Schedule I. 


\section{Article 8. Licences}

1. The Parties shall require that the manufacture of, trade (including export and import trade) in, and distribution of substances listed in Schedules II, III and IV be under licence or other similar control measure.

2. The Parties shall:

(a) Control all duly authorized persons and enterprises carrying on or engaged in the manufacture of, trade (including export and import trade) in, or distribution of substances referred to in paragraph 1;

(b) Control under licence or other similar control measure the establishments and premises in which such manufacture, trade or distribution may take place; and

(c) Provide that security measures be taken with regard to such establishments and premises in order to prevent theft or other diversion of stocks.

3. The provisions of paragraphs 1 and 2 of this article relating to licensing or other similar control measures need not apply to persons duly authorized to perform and while performing therapeutic or scientific functions.

4. The Parties shall require that all persons who obtain licences in accordance with this Convention or who are otherwise authorized pursuant to paragraph 1 of this article or sub-paragraph (b) of article 7 shall be adequately qualified for the effective and faithful execution of the provisions of such laws and regulations as are enacted in pursuance of this Convention.

\section{Article 9. Prescriptions}

1. The Parties shall require that substances in Schedules II, III and IV be supplied or dispensed for use by individuals pursuant to medical prescription only, except when individuals may lawfully obtain, use, dispense or administer such substances in the duly authorized exercise of therapeutic or scientific functions.

2. The Parties shall take measures to ensure that prescriptions for substances in Schedules II, III and IV are issued in accordance with sound medical 
practice and subject to such regulation, particularly as to the number of times they may be refilled and the duration of their validity, as will protect the public health and welfare.

3. Notwithstanding paragraph 1, a Party may, if in its opinion local circumstances so require and under such conditions, including record-keeping, as it may prescribe, authorize licensed pharmacists or other licensed retail distributors designated by the authorities responsible for public health in its country or part thereof to supply, at their discretion and without prescription, for use for medical purposes by individuals in exceptional cases, small quantities, within limits to be defined by the Parties, of substances in Schedules III and IV.

\section{Article 10. Warnings on packages, and advertising}

1. Each Party shall require, taking into account any relevant regulations or recommendations of the World Health Organization, such directions for use, including cautions and warnings, to be indicated on the labels where practicable and in any case on the accompanying leaflet of retail packages of psychotropic substances, as in its opinion are necessary for the safety of the user.

2. Each Party shall, with due regard to its constitutional provisions, prohibit the advertisement of such substances to the general public.

\section{Article 11. Records}

1. The Parties shall require that, in respect of substances in Schedule I, manufactures and all other persons authorized under article 7 to trade in and distribute those substances keep records, as may be determined by each Party, showing details of the quantities manufactured, the quantities held in stock, and, for each acquisition and disposal, details of the quantity, date, supplier and recipient.

2. The Parties shall require that, in respect of substances in Schedules II and III, manufacturers, wholesale distributors, exporters and importers keep records, as may be determined by each Party, showing details of the quantities manufactured and, for each acquisition and disposal, details of the quantity, date, supplier and recipient. 
3. The Parties shall require that, in respect of substances in Schedule II, retail distributors, institutions for hospitalization and care and scientific institutions keep records, as may be determined by each Party, showing, for each acquisition and disposal, details of the quantity, date, supplier and recipient.

4. The Parties shall ensure, through appropriate methods and taking into account the professional and trade practices in their countries, that information regarding acquisition and disposal of substances in Schedule III by retail distributors, institutions for hospitalization and care and scientific institutions is readily available.

5. The Parties shall require that, in respect of substances in Schedule IV, manufacturers, exporters and importers keep records, as may be determined by each Party, showing the quantities manufactured, exported and imported.

6. The Parties shall require manufacturers of preparations exempted under paragraph 3 of article 3 to keep records as to the quantity of each psychotropic substance used in the manufacture of an exempt preparation, and as to the nature, total quantity and initial disposal of the exempt preparation manufactured therefrom.

7. The Parties shall ensure that the records and information referred to in this article which are required for purposes of reports under article 16 shall be preserved for at least two years.

\section{Article 12. Provisions relating to international trade}

1. (a) Every Party permitting the export or import of substances in Schedule I or II shall require a separate import or export authorization, on a form to be established by the Commission, to be obtained for each such export or import whether it consists of one or more substances.

(b) Such authorization shall state the international non-proprietary name, or, lacking such a name, the designation of the substance in the Schedule, the quantity to be exported or imported, the pharmaceutical form, the name and address of the exporter and importer, and the period within which the export or import must be effected. If the substance is exported or imported in the form of a preparation, the name of the preparation, if any, shall additionally 
be furnished. The export authorization shall also state the number and date of the import authorization and the authority by whom it has been issued.

(c) Before issuing an export authorization the Parties shall require an import authorization, issued by the competent authority of the importing country or region and certifying that the importation of the substance or substances referred to therein is approved, and such an authorization shall be produced by the person or establishment applying for the export authorization.

(d) A copy of the export authorization shall accompany each consignment, and the Government issuing the export authorization shall send a copy to the Government of the importing country or region.

(e) The Government of the importing country or region, when the importation has been effected, shall return the export authorization with an endorsement certifying the amount actually imported, to the Government of the exporting country or region.

2. (a) The Parties shall require that for each export of substances in Schedule III exporters shall draw up a declaration in triplicate, on a form to be established by the Commission, containing the following information:

(i) The name and address of the exporter and importer;

(ii) The international non-proprietary name, or, failing such a name, the designation of the substance in the Schedule;

(iii) The quantity and pharmaceutical form in which the substance is exported, and, if in the form of a preparation, the name of the preparation, if any; and

(iv) The date of despatch.

(b) Exporters shall furnish the competent authorities of their country or region with two copies of the declaration. They shall attach the third copy to their consignment.

(c) A Party from whose territory a substance in Schedule III has been exported shall, as soon as possible but not later than ninety days after the date of despatch, send to the competent authorities of the importing country or region, by registered mail with return of receipt requested, one copy of the declaration received from the exporter. 
(d) The Parties may require that, on receipt of the consignment, the importer shall transmit the copy accompanying the consignment, duly endorsed stating the quantities received and the date of receipt, to the competent authorities of his country or region.

3. In respect of substances in Schedules I and II the following additional provisions shall apply:

(a) The Parties shall exercise in free ports and zones the same supervision and control as in other parts of their territory, provided, however, that they may apply more drastic measures.

(b) Exports of consignments to a post office box, or to a bank to the account of a person other than the person named in the export authorization, shall be prohibited.

(c) Exports to bonded warehouses of consignments of substances in Schedule I are prohibited. Exports of consignments of substances in Schedule II to a bonded warehouse are prohibited unless the Government of the importing country certifies on the import authorization, produced by the person or establishment applying for the export authorization, that it has approved the importation for the purpose of being placed in a bonded warehouse. In such case the export authorization shall certify that the consignment is exported for such purpose. Each withdrawal from the bonded warehouse shall require a permit from the authorities having jurisdiction over the warehouse and, in the case of a foreign destination, shall be treated as if it were a new export within the meaning of this Convention.

(d) Consignments entering or leaving the territory of a Party not accompanied by an export authorization shall be detained by the competent authorities.

(e) A Party shall not permit any substances consigned to another country to pass through its territory, whether or not the consignment is removed from the conveyance in which it is carried, unless a copy of the export authorization for consignment is produced to the competent authorities of such Party.

(f) The competent authorities of any country or region through which a consignment of substances is permitted to pass shall take all due measures to prevent the diversion of the consignment to a destination other than that named in the accompanying copy of the export authorization, unless the Government of the country or region through which the consignment is passing authorizes 
the diversion. The Government of the country or region of transit shall treat any requested diversion as if the diversion were an export from the country or region of transit to the country or region of new destination. If the diversion is authorized, the provisions of paragraph 1 (e) shall also apply between the country or region of transit and the country or region which originally exported the consignment.

(g) No consignment of substances, while in transit or whilst being stored in a bonded warehouse, may be subjected to any process which would change the nature of the substance in question. The packing may not be altered without the permission of the competent authorities.

(b) The provisions of sub-paragraphs (e) to $(g)$ relating to the passage of substances through the territory of a Party do not apply where the consignment in question is transported by aircraft which does not land in the country or region of transit. If the aircraft lands in any such country or region, those provisions shall be applied so far as circumstances require.

(i) The provisions of this paragraph are without prejudice to the provisions of any international agreements which limit the control which may be exercised by any of the Parties over such substances in transit.

\section{Article 13. Prohibition of and restrictions on export and import}

1. A Party may notify all the other Parties through the Secretary-General that it prohibits the import into its country or into one of its regions of one or more substances in Schedule II, III or IV, specified in its notification. Any such notification shall specify the name of the substance as designated in Schedule II, III or IV.

2. If a Party has been notified of a prohibition pursuant to paragraph 1, it shall take measures to ensure that none of the substances specified in the notification is exported to the country or one of the regions of the notifying Party.

3. Notwithstanding the provisions of the preceding paragraphs, a Party which has given notification pursuant to paragraph 1 may authorize by special import licence in each case the import of specified quantities of the substances in question or preparations containing such substances. The issuing authority of the importing country shall send two copies of the special import licence, 
indicating the name and address of the importer and the exporter, to the competent authority of the exporting country or region, which may then authorize the exporter to make the shipment. One copy of the special import licence, duly endorsed by the competent authority of the exporting country or region, shall accompany the shipment.

Article 14. Special provisions concerning the carriage of psychotropic substances in first-aid kits of ships, aircraft or other forms of public transport engaged in international traffic

1. The international carriage by ships, aircraft or other forms of international public transport, such as international railway trains and motor coaches, of such limited quantities of substances in Schedule II, III or IV as may be needed during their journey or voyage for first-aid purposes or emergency cases shall not be considered to be export, import or passage through a country within the meaning of this Convention.

2. Appropriate safeguards shall be taken by the country of registry to prevent the improper use of the substances referred to in paragraph 1 or their diversion for illicit purposes. The Commission, in consultation with the appropriate international organizations, shall recommend such safeguards.

3. Substances carried by ships, aircraft or other forms of international public transport, such as international railway trains and motor coaches, in accordance with paragraph 1 shall be subject to the laws, regulations, permits and licences of the country of registry, without prejudice to any rights of the competent local authorities to carry out checks, inspections and other control measures on board these conveyances. The administration of such substances in the case of emergency shall not be considered a violation of the requirements of paragraph 1 of article 9 .

\section{Article 15. Inspection}

The Parties shall maintain a system of inspection of manufacturers, exporters, importers, and wholesale and retail distributors of psychotropic substances and of medical and scientific institutions which use such substances. They shall 
provide for inspections, which shall be made as frequently as they consider necessary, of the premises and of stocks and records.

\section{Article 16. Reports to be furnished by the Parties}

1. The Parties shall furnish to the Secretary-General such information as the Commission may request as being necessary for the performance of its functions, and in particular an annual report regarding the working of the Convention in their territories including information on:

(a) Important changes in their laws and regulations concerning psychotropic substances; and

(b) Significant developments in the abuse of and the illicit traffic in psychotropic substances within their territories.

2. The Parties shall also notify the Secretary-General of the names and addresses of the governmental authorities referred to in sub-paragraph $(f)$ of article 7 , in article 12 and in paragraph 3 of article 13 . Such information shall be made available to all Parties by the Secretary-General.

3. The Parties shall furnish, as soon as possible after the event, a report to the Secretary-General in respect of any case of illicit traffic in psychotropic substances or seizure from such illicit traffic which they consider important because of:

(a) New trends disclosed;

(b) The quantities involved;

(c) The light thrown on the sources from which the substances are obtained; or

(d) The methods employed by illicit traffickers.

Copies of the report shall be communicated in accordance with sub-paragraph (b) of article 21 .

4. The Parties shall furnish to the Board annual statistical reports in accordance with forms prepared by the Board: 
(a) In regard to each substance in Schedules I and II, on quantities manufactured, exported to and imported from each country or region as well as on stocks held by manufacturers;

(b) In regard to each substance in Schedules III and IV, on quantities manufactured, as well as on total quantities exported and imported;

(c) In regard to each substance in Schedules II and III, on quantities used in the manufacture of exempt preparations; and

(d) In regard to each substance other than a substance in Schedule I, on quantities used for industrial purposes in accordance with sub-paragraph (b) of article 4 .

The quantities manufactured which are referred to in sub-paragraphs (a) and (b) of this paragraph do not include the quantities of preparations manufactured.

5. A Party shall furnish the Board, on its request, with supplementary statistical information relating to future periods on the quantities of any individual substance in Schedules III and IV exported to and imported from each country or region. That Party may request that the Board treat as confidential both its request for information and the information given under this paragraph.

6. The Parties shall furnish the information referred to in paragraphs 1 and 4 in such a manner and by such dates as the Commission or the Board may request.

\section{Article 17. Functions of the Commission}

1. The Commission may consider all matters pertaining to the aims of this Convention and to the implementation of its provisions, and may make recommendations relating thereto.

2. The decisions of the Commission provided for in articles 2 and 3 shall be taken by a two-thirds majority of the members of the Commission.

\section{Article 18. Reports of the Board}

1. The Board shall prepare annual reports on its work containing an analysis of the statistical information at its disposal, and, in appropriate cases, 
an account of the explanations, if any, given by or required of Governments, together with any observations and recommendations which the Board desires to make. The Board may make such additional reports as it considers necessary. The reports shall be submitted to the Council through the Commission, which may make such comments as it sees fit.

2. The reports of the Board shall be communicated to the Parties and subsequently published by the Secretary-General. The Parties shall permit their unrestricted distribution.

\section{Article 19. Measures by the Board to ensure the execution of the provisions of the Convention}

1. (a) If, on the basis of its examination of information submitted by governments to the Board or of information communicated by United Nations organs, the Board has reason to believe that the aims of this Convention are being seriously endangered by reason of the failure of a country or region to carry out the provisions of this Convention, the Board shall have the right to ask for explanations from the Government of the country or region in question. Subject to the right of the Board to call the attention of the Parties, the Council and the Commission to the matter referred to in sub-paragraph (c) below, it shall treat as confidential a request for information or an explanation by a government under this sub-paragraph.

(b) After taking action under sub-paragraph (a), the Board, if satisfied that it is necessary to do so, may call upon the Government concerned to adopt such remedial measures as shall seem under the circumstances to be necessary for the execution of the provisions of this Convention.

(c) If the Board finds that the Government concerned has failed to give satisfactory explanations when called upon to do so under sub-paragraph (a), or has failed to adopt any remedial measures which it has been called upon to take under sub-paragraph (b), it may call the attention of the Parties, the Council and the Commission to the matter.

2. The Board, when calling the attention of the Parties, the Council and the Commission to a matter in accordance with paragraph 1 (c), may, if it is satisfied that such a course is necessary, recommend to the Parties that they 
stop the export, import, or both, of particular psychotropic substances, from or to the country or region concerned, either for a designated period or until the Board shall be satisfied as to the situation in that country or region. The State concerned may bring the matter before the Council.

3. The Board shall have the right to publish a report on any matter dealt with under the provisions of this article, and communicate it to the Council, which shall forward it to all Parties. If the Board publishes in this report a decision taken under this article or any information relating thereto, it shall also publish therein the views of the Government concerned if the latter so requests.

4. If in any case a decision of the Board which is published under this article is not unanimous, the views of the minority shall be stated.

5. Any State shall be invited to be represented at a meeting of the Board at which a question directly interesting it is considered under this article.

6. Decisions of the Board under this article shall be taken by a twothirds majority of the whole number of the Board.

7. The provisions of the above paragraphs shall also apply if the Board has reason to believe that the aims of this Convention are being seriously endangered as a result of a decision taken by a Party under paragraph 7 of article 2 .

\section{Article 20. Measures against the abuse of psychotropic substances}

1. The Parties shall take all practicable measures for the prevention of abuse of psychotropic substances and for the early identification, treatment, education, after-care, rehabilitation and social reintegration of the persons involved, and shall co-ordinate their efforts to these ends.

2. The Parties shall as far as possible promote the training of personnel in the treatment, after-care, rehabilitation and social reintegration of abusers of psychotropic substances.

3. The Parties shall assist persons whose work so requires to gain an understanding of the problems of abuse of psychotropic substances and of its 
prevention, and shall also promote such understanding among the general public if there is a risk that abuse of such substances will become widespread.

\section{Article 21. Action against the illicit traffic}

Having due regard to their constitutional, legal and administrative systems, the Parties shall:

(a) Make arrangements at the national level for the co-ordination of preventive and repressive action against the illicit traffic; to this end they may usefully designate an appropriate agency responsible for such co-ordination;

(b) Assist each other in the campaign against the illicit traffic in psychotropic substances, and in particular immediately transmit, through the diplomatic channel or the competent authorities designated by the Parties for this purpose, to the other Parties directly concerned, a copy of any report addressed to the Secretary-General under article 16 in connexion with the discovery of a case of illicit traffic or a seizure;

(c) Co-operate closely with each other and with the competent international organizations of which they are members with a view to maintaining a co-ordinated campaign against the illicit traffic;

(d) Ensure that international co-operation between the appropriate agencies be conducted in an expeditious manner; and

(e) Ensure that, where legal papers are transmitted internationally for the purpose of judicial proceedings, the transmittal be effected in an expeditious manner to the bodies designated by the Parties; this requirement shall be without prejudice to the right of a Party to require that legal papers be sent to it through the diplomatic channel.

\section{Article 22. Penal provisions}

1. (a) Subject to its constitutional limitations, each Party shall treat as a punishable offence, when committed intentionally, any action contrary to a law or regulation adopted in pursuance of its obligations under this Convention, and shall ensure that serious offences shall be liable to adequate punishment, particularly by imprisonment or other penalty of deprivation of liberty. 
(b) Notwithstanding the preceding sub-paragraph, when abusers of psychotropic substances have committed such offences, the Parties may provide, either as an alternative to conviction or punishment or in addition to punishment, that such abusers undergo measures of treatment, education, aftercare, rehabilitation and social reintegration in conformity with paragraph 1 of article 20 .

2. Subject to the constitutional limitations of a Party, its legal system and domestic law,

(a) (i) If a series of related actions constituting offences under paragraph 1 has been committed in different countries, each of them shall be treated as a distinct offence;

(ii) Intentional participation in, conspiracy to commit and attempts to commit, any of such offences, and preparatory acts and financial operations in connexion with the offences referred to in this article, shall be punishable offences as provided in paragraph 1;

(iii) Foreign convictions for such offences shall be taken into account for the purpose of establishing recidivism; and

(iv) Serious offences heretofore referred to committed either by nationals or by foreigners shall be prosecuted by the Party in whose territory the offence was committed, or by the Party in whose territory the offender is found if extradition is not acceptable in conformity with the law of the Party to which application is made, and if such offender has not already been prosecuted and judgement given.

(b) It is desirable that the offences referred to in paragraph 1 and paragraph 2 (a) (ii) be included as extradition crimes in any extradition treaty which has been or may hereafter be concluded between any of the Parties, and, as between any of the Parties which do not make extradition conditional on the existence of a treaty or on reciprocity, be recognized as extradition crimes; provided that extradition shall be granted in conformity with the law of the Party to which application is made, and that the Party shall have the right to refuse to effect the arrest or grant the extradition in cases where the competent authorities consider that the offence is not sufficiently serious. 
3. Any psychotropic substance or other substance, as well as any equipment, used in or intended for the commission of any of the offences referred to in paragraphs 1 and 2 shall be liable to seizure and confiscation.

4. The provisions of this article shall be subject to the provisions of the domestic law of the Party concerned on questions of jurisdiction.

5. Nothing contained in this article shall affect the principle that the offences to which it refers shall be defined, prosecuted and punished in conformity with the domestic law of a Party.

Article 23. Application of stricter control measures than those required by this Convention

A Party may adopt more strict or severe measures of control than those provided by this Convention if, in its opinion, such measures are desirable or necessary for the protection of the public health and welfare.

\section{Article 24. Expenses of international organs incurred in administering the provisions of the Convention}

The expenses of the Commission and the Board in carrying out their respective functions under this Convention shall be borne by the United Nations in such manner as shall be decided by the General Assembly. The Parties which are not Members of the United Nations shall contribute to these expenses such amounts as the General Assembly finds equitable and assesses from time to time after consultation with the Governments of these Parties.

Article 25. Procedure for admission, signature, ratification and accession

1. Members of the United Nations, States not Members of the United Nations which are members of a specialized agency of the United Nations or of the International Atomic Energy Agency or Parties to the Statute of the 
International Court of Justice, and any other State invited by the Council, may become Parties to this Convention:

(a) By signing it; or

(b) By ratifying it after signing it subject to ratification; or

(c) By acceding to it.

2. The Convention shall be open for signature until 1 January 1972 inclusive. Thereafter it shall be open for accession.

3. Instruments of ratification or accession shall be deposited with the Secretary-General.

\section{Article 26. Entry into force}

1. The Convention shall come into force on the ninetieth day after forty of the States referred to in paragraph 1 of article 25 have signed it without reservation of ratification or have deposited their instruments of ratification or accession.

2. For any other State signing without reservation of ratification, or depositing an instrument of ratification or accession after the last signature or deposit referred to in the preceding paragraph, the Convention shall enter into force on the ninetieth day following the date of its signature or deposit of its instrument of ratification or accession.

\section{Article 27. Territorial application}

The Convention shall apply to all non-metropolitan territories for the international relations of which any Party is responsible except where the previous consent of such a territory is required by the Constitution of the Party or of the territory concerned, or required by custom. In such a case the Party shall endeavour to secure the needed consent of the territory within the shortest period possible, and when the consent is obtained the Party shall notify the Secretary-General. The Convention shall apply to the territory or territories named in such a notification from the date of its receipt by the Secretary-General. 
In those cases where the previous consent of the non-metropolitan territory is not required, the Party concerned shall, at the time of signature, ratification or accession, declare the non-metropolitan territory or territories to which this Convention applies.

\section{Article 28. Regions for the purposes of this Convention}

1. Any Party may notify the Secretary-General that, for the purposes of this Convention, its territory is divided into two or more regions, or that two or more of its regions are consolidated into a single region.

2. Two or more Parties may notify the Secretary-General that, as the result of the establishment of a customs union between them, those Parties constitute a region for the purposes of this Convention.

3. Any notification under paragraph 1 or 2 shall take effect on 1 January of the year following the year in which the notification was made.

\section{Article 29. Denunciation}

1. After the expiry of two years from the date of the coming into force of this Convention any Party may, on its own behalf or on behalf of a territory for which it has international responsibility, and which has withdrawn its consent given in accordance with article 27 , denounce this Convention by an instrument in writing deposited with the Secretary-General.

2. The denunciation, if received by the Secretary-General on or before the first day of July of any year, shall take effect on the first day of January of the succeeding year, and if received after the first day of July it shall take effect as if it had been received on or before the first day of July in the succeeding year.

3. The Convention shall be terminated if, as a result of denunciations made in accordance with paragraphs 1 and 2, the conditions for its coming into force as laid down in paragraph 1 of article 26 cease to exist. 


\section{Article 30. Amendments}

1. Any Party may propose an amendment to this Convention. The text of any such amendment and the reasons therefor shall be communicated to the Secretary-General, who shall communicate them to the Parties and to the Council. The Council may decide either:

(a) That a conference shall be called in accordance with paragraph 4 of Article 62 of the Charter of the United Nations to consider the proposed amendment; or

(b) That the Parties shall be asked whether they accept the proposed amendment and also asked to submit to the Council any comments on the proposal.

2. If a proposed amendment circulated under paragraph 1 (b) has not been rejected by any Party within eighteen months after it has been circulated, it shall thereupon enter into force. If, however, a proposed amendment is rejected by any Party, the Council may decide, in the light of comments received from Parties, whether a conference shall be called to consider such amendment.

\section{Article 31. Disputes}

1. If there should arise between two or more Parties a dispute relating to the interpretation or application of this Convention, the said Parties shall consult together with a view to the settlement of the dispute by negotiation, investigation, mediation, conciliation, arbitration, recourse to regional bodies, judicial process or other peaceful means of their own choice.

2. Any such dispute which cannot be settled in the manner prescribed shall be referred, at the request of any one of the parties to the dispute, to the International Court of Justice for decision.

\section{Article 32. Reservations}

1. No reservation other than those made in accordance with paragraphs 2, 3 and 4 of the present article shall be permitted. 
2. Any State may at the time of signature, ratification or accession make reservations in respect of the following provisions of the present Convention:

(a) Article 19, paragraphs 1 and 2;

(b) Article 27; and

(c) Article 31

3. A State which desires to become a Party but wishes to be authorized to make reservations other than those made in accordance with paragraphs 2 and 4 may inform the Secretary-General of such intention. Unless by the end of twelve months after the date of the Secretary-General's communication of the reservation concerned, this reservation has been objected to by one third of the States that have signed without reservation of ratification, ratified or acceded to this Convention before the end of that period, it shall be deemed to be permitted, it being understood, however, that States which have objected to the reservation need not assume towards the reserving State any legal obligation under this Convention which is affected by the reservation.

4. A State on whose territory there are plants growing wild which contain psychotropic substances from among those in Schedule I and which are traditionally used by certain small, clearly determined groups in magical or religious rites, may, at the time of signature, ratification or accession, make reservations concerning these plants, in respect of the provisions of article 7 , except for the provisions relating to international trade.

5. A State which has made reservations may at any time by notification in writing to the Secretary-General withdraw all or part of its reservations.

\section{Article 33. Notifications}

The Secretary-General shall notify to all the States referred to in paragraph 1 of article 25:

(a) Signatures, ratifications and accessions in accordance with article 25;

(b) The date upon which this Convention enters into force in accordance with article 26; 
(c) Denunciations in accordance with article 29; and

(d) Declarations and notifications under articles 27, 28, 30 and 32.

IN WITNESS WHEREOF, the undersigned, duly authorized, have signed this Convention on behalf of their respective Governments.

DONE at Vienna, this twenty-first day of February one thousand nine hundred and seventy-one, in a single copy in the Chinese, English, French, Russian and Spanish languages, each being equally authentic. The Convention shall be deposited with the Secretary-General of the United Nations, who shall transmit certified true copies thereof to all the Members of the United Nations and to the other States referred to in paragraph 1 of article 25.

Note: The revised list of substances in Schedules I, II, III and IV of the Convention on Psychotropic Substances of 1971, is contained in ST/CND/1/Add.2. 
Part Three

\section{UNITED NATIONS CONVENTION AGAINST ILLICIT TRAFFIC IN NARCOTIC DRUGS AND PSYCHOTROPIC SUBSTANCES OF 1988}

including Final Act and Resolutions, as agreed by the United Nations

Conference for the Adoption of a Convention against Illicit Traffic in Narcotic Drugs and Psychotropic Substances 



\section{Contents}

United Nations Conference for the Adoption of a Convention against

Illicit Traffic in Narcotic Drugs and Psychotropic Substances.

Final Act

Resolutions

United Nations Conventions against Illicit Traffic in Narcotic Drugs and Psychotropic Substances

Article 1. Definitions

Article 2. Scope of the Convention ........................................................ 127

Article 3. Offences and sanctions .......................................................... 127

Article 4. Jurisdiction ....................................................................... 131

Article 5. Confiscation ............................................................................. 132

Article 6. Extradition ............................................................................. 136

Article 7. Mutual legal assistance ........................................................ 137

Article 8. Transfer of proceedings ........................................................ 141

Article 9. Other forms of co-operation and training ................................ 141

Article 10. International co-operation and assistance for transit States.......... 143

Article 11. Controlled delivery ............................................................... 144

Article 12. Substances frequently used in the illicit manufacture of narcotic drugs or psychotropic substances

Article 13. Materials and equipment ......................................................... 148

Article 14. Measures to eradicate illicit cultivation of narcotic plants and to eliminate illicit demand for narcotic drugs and psychotropic substances

Article 15. Commercial carriers 
Article 16. Commercial documents and labelling of exports.

Article 17. Illicit traffic by sea

Article 18. Free trade zones and free ports

Article 19. The use of the mails

Article 20. Information to be furnished by Parties

Article 21. Functions of the Commission.................................................... 154

Article 22. Functions of the Board ........................................................ 155

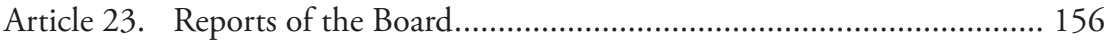

Article 24. Application of stricter measures than those required by this Convention ................................................................... 156

Article 25. Non-derogation from earlier treaty rights and obligations........... 156

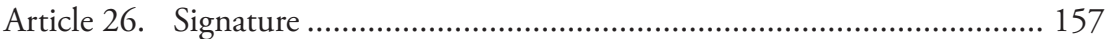

Article 27. Ratification, acceptance, approval or act of formal confirmation .. 157

Article 28. Accession

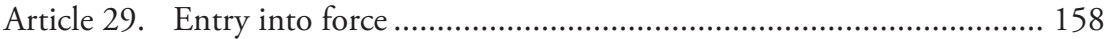

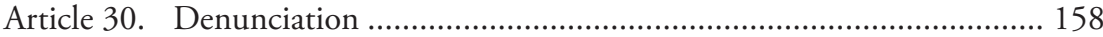

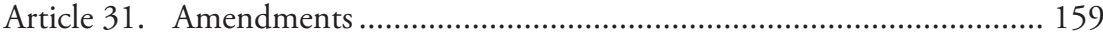

Article 32. Settlement of disputes............................................................. 159

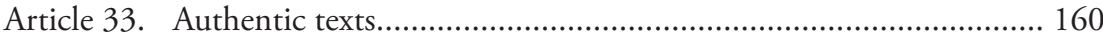

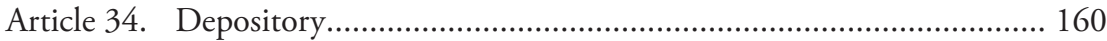




\section{Final Act of the United Nations Conference for the Adoption of a Convention against Illicit Traffic in Narcotic Drugs and Psychotropic Substances}

1. The General Assembly of the United Nations, by its resolution 39/141 of 14 December 1984, requested the Economic and Social Council of the United Nations, "taking into consideration Article 62, paragraph 3, and Article 66, paragraph 1, of the Charter of the United Nations and Council resolution 9 (I) of 16 February 1946, to request the Commission on Narcotic Drugs to initiate at its thirty-first session, to be held in February 1985, as a matter of priority, the preparation of a draft convention against illicit traffic in narcotic drugs which considers the various aspects of the problem as a whole and, in particular, those not envisaged in existing international instruments ...".

2. In furtherance of the foregoing request, and the follow-up action by the Commission on Narcotic Drugs and the Economic and Social Council, the Secretary-General of the United Nations prepared the initial text of a draft Convention against Illicit Traffic in Narcotic Drugs and Psychotropic Substances. On the basis of the comments made thereon by Governments and the deliberations of the Commission on Narcotic Drugs on that draft at its thirty-second session in 1987, the Secretary-General prepared a consolidated working document, which was circulated to all Governments in April 1987 and was considered at two sessions of an open-ended intergovernmental expert group. On 7 December 1987, the General Assembly adopted resolution 42/111, which gave further instructions for advancing the preparation of the draft Convention. As the time available to the expert group had not permitted thorough consideration of all the articles, the General Assembly requested the Secretary-General to consider convening a further intergovernmental expert group, meeting for two weeks immediately prior to the tenth special session of the Commission on Narcotic Drugs in February 1988, to continue revision of the working document on the draft Convention against Illicit Traffic in Narcotic Drugs and Psychotropic Substances and, if possible, to reach agreement on the Convention. At its tenth special session, held at Vienna from 8 to 19 February 1988, the Commission on Narcotic Drugs reviewed the text of the draft Convention and decided that certain articles thereof should be referred to the Conference to be convened to adopt a Convention. The Commission also recommended certain means to the Economic and Social Council to further the preparation of the draft Convention. 
3. The Economic and Social Council, by its resolution 1988/8 of 25 May 1988, having recalled the preparatory work undertaken pursuant to General Assembly resolution 39/141 by the competent United Nations organs, decided "to convene, in accordance with Article 62, paragraph 4, of the Charter of the United Nations and within the provisions of General Assembly resolution 366 (IV) of 3 December 1949, a conference of plenipotentiaries for the adoption of a convention against illicit traffic in narcotic drugs and psychotropic substances". By its decision 1988/120, also adopted on 25 May 1988, the Council decided that the Conference should be held at Vienna from 25 November to 20 December 1988 and that the Secretary-General should send invitations to participate in the Conference to those who had been invited to participate in the International Conference on Drug Abuse and Illicit Trafficking, held at Vienna from 17 to 26 June 1987.

4. By its resolution 1988/8, the Economic and Social Council also decided to convene a review group for the Conference to review the draft texts of certain articles and the draft Convention as a whole to achieve overall consistency in the text to be submitted to the Conference. The Review Group on the draft Convention met at the United Nations Office at Vienna from 27 June to 8 July 1988 and adopted a report to the Conference (E/CONF.82/3).

5. The United Nations Conference for the Adoption of a Convention against Illicit Traffic in Narcotic Drugs and Psychotropic Substances met at the Neue Hofburg at Vienna from 25 November to 20 December 1988.

6. Pursuant to Economic and Social Council resolution 1988/8 of 25 May 1988 and its decision 1988/120 of the same date, the Secretary-General invited to the Conference:

(a) All States;

(b) Namibia, represented by the United Nations Council for Namibia;

(c) Representatives of organizations that have received a standing invitation from the General Assembly to participate in the sessions and the work of all international conferences convened under its auspices in the capacity of observers to participate in the Conference in that capacity, in accordance with Assembly resolutions 3237 (XXIX) of 22 November 1974 and 31/152 of 20 December 1976; 
(d) Representatives of the national liberation movements recognized in its region by the Organization of African Unity to participate in the Conference in the capacity of observers, in accordance with General Assembly resolution 3280 (XXIX) of 10 December 1974;

(e) The specialized agencies and the International Atomic Energy Agency, as well as interested organs of the United Nations, to be represented at the Conference;

(f) Other interested intergovernmental organizations to be represented by observers at the Conference;

(g) Interested non-governmental organizations in consultative status with the Economic and Social Council and other interested non-governmental organizations that may have a specific contribution to make to the work of the Conference to be represented by observers at the Conference.

7. The delegations of the following 106 States participated in the Conference: Afghanistan, Albania, Algeria, Argentina, Australia, Austria, Bahamas, Bahrain, Bangladesh, Barbados, Belgium, Bolivia, Botswana, Brazil, Bulgaria, Burma, Byelorussian Soviet Socialist Republic, Cameroon, Canada, Cape Verde, Chile, China, Colombia, Costa Rica, Côte d'lvoire, Cuba, Cyprus, Czechoslovakia, Denmark, Dominican Republic, Ecuador, Egypt, Ethiopia, Finland, France, German Democratic Republic, Germany, Federal Republic of, Ghana, Greece, Guatemala, Guinea, Holy See, Honduras, Hungary, India, Indonesia, Iran (Islamic Republic of), Iraq, Ireland, Israel, Italy, Jamaica, Japan, Jordan, Kenya, Kuwait, Libyan Arab Jamahiriya, Luxembourg, Madagascar, Malaysia, Malta, Mauritania, Mauritius, Mexico, Monaco, Morocco, Nepal, Netherlands, New Zealand, Nicaragua, Nigeria, Norway, Oman, Pakistan, Panama, Papua New Guinea, Paraguay, Peru, Philippines, Poland, Portugal, Qatar, Republic of Korea, Saudi Arabia, Senegal, Spain, Sri Lanka, Sudan, Suriname, Sweden, Switzerland, Thailand, Tunisia, Turkey, Ukrainian Soviet Socialist Republic, Union of Soviet Socialist Republics, United Arab Emirates, United Kingdom of Great Britain and Northern Ireland, United Republic of Tanzania, United States of America, Uruguay, Venezuela, Viet Nam, Yemen, Yugoslavia and Zaire.

8. The representatives of the following national liberation movements, invited to the Conference by the Secretary-General, attended and participated as provided for in the rules of procedure of the Conference (E/CONF.82/7): Pan Africanist Congress of Azania and South West Africa People's Organization. 
9. The representatives of the following specialized agencies, invited to the Conference by the Secretary-General, attended and participated as provided for in the rules of procedure of the Conference: International Civil Aviation Organization, International Labour Organisation, United Nations Educational, Scientific and Cultural Organization, United Nations Industrial Development Organization and World Health Organization.

10. The representatives of the following other intergovernmental organizations, invited to the Conference by the Secretary-General, attended and participated as provided for in the rules of procedure of the Conference: Arab Security Studies and Training Center, Colombo Plan Bureau, Council of Europe, Customs Co-operation Council, European Economic Community, International Criminal Police Organization, League of Arab States and South American Agreement on Narcotic Drugs and Psychotropic Substances.

11. The representatives of the following interested United Nations organs and related bodies, invited to the Conference by the Secretary-General, attended and participated as provided for in the rules of procedure of the Conference: Centre for Social Development and Humanitarian Affairs, International Narcotics Control Board, United Nations Asia and Far East Institute for the Prevention of Crime and the Treatment of Offenders and United Nations Fund for Drug Abuse Control.

12. Observers from the following non-governmental organizations, invited to the Conference by the Secretary-General, attended and participated as provided for in the rules of procedure of the Conference: Baha'i International Community, Caritas Internationalis, Centro Italiano de Solidarità, Colombia Therapeutic Communities, Co-ordinating Board of Jewish Organizations, Cruz Blanca Panama, Drug Abuse Prevention Programme, European Union of Women, Integrative Drogenhilfe a.d. Fachhochschule Ffm. e.v., International Abolitionist Federation, International Advertising Association, International Air Transport Association, International Association of Democratic Jurists, International Association of Lions Clubs, International Catholic Child Bureau, International Chamber of Commerce, International Confederation of Free Trade Unions, International Council on Women, International Council of Alcohol and Addictions, International Federation of Business and Professional Women, International Federation of Social Workers, International Pharmaceutical Federation, International Schools Association, Islamic African Relief Agency, Opium De-addiction Treatment, Training and Research Trust, Pace United Kingdom 
International Affairs, Pax Romana, Soroptimist International, World Association of Girl Guides and Girl Scouts, World Union of Catholic Women's Organizations and Zonta International Committee.

13. The Conference elected Mr. Guillermo Bedregal Gutiérrez (Bolivia) as President.

14. The Conference elected as Vice-Presidents the representatives of the following States: Algeria, Argentina, Bahamas, China, Côte d'lvoire, France, Iran (Islamic Republic of), Japan, Kenya, Malaysia, Mexico, Morocco, Nigeria, Pakistan, Philippines, Senegal, Sudan, Sweden, Turkey, Union of Soviet Socialist Republics, United Kingdom of Great Britain and Northern Ireland, United States of America, Venezuela and Yugoslavia.

15. The Conference elected Mrs. Mervat Tallawy (Egypt) as Rapporteur-General.

16. The following Committees were set up by the Conference:

\section{General Committee}

Chairman: The President of the Conference

Members: The President and Vice-Presidents of the Conference, the Rapporteur-General of the Conference, the Chairmen of the Committees of the Whole and the Chairman of the Drafting Committee.

\section{Committees of the Whole}

\section{Committee I}

Chairman: Mr. Gioacchino Polimeni (Italy)

Vice-Chairman: Mr. M.A. Hena (Bangladesh)

Rapporteur: Mr. Oskar Hugler (German Democratic Republic)

\section{Committee II}

Chairman: Mr. István Bayer (Hungary)

Vice-Chairman: Mr. L.H.J.B. van Gorkom (Netherlands)

Rapporteur: Mrs. Yolanda Fernández Ochoa (Costa Rica) 


\section{Drafting Committee}

Chairman: Mr. M.V.N. Rao (India)

Vice-Chairman: Mr. Hashem M. Kuraa (Egypt)

Members: The Chairman of the Drafting Committee and the representatives of the following States: Australia, Botswana, Canada, China, Colombia, Czechoslovakia, Egypt, France, Ghana, Iraq, Peru, Senegal, Spain and Union of Soviet Socialist Republics.

The Rapporteurs of the Committees of the Whole participated ex officio in the work of the Drafting Committee in accordance with rule 49 of the rules of procedure of the Conference.

\section{Credentials Committee}

Chairman: Mr. Edouard Molitor (Luxembourg)

Members: The representatives of the following States: Bolivia, Botswana, China, Côte d'lvoire, Jamaica, Luxembourg, Thailand, Union of Soviet Socialist Republics and United States of America.

17. The Secretary-General of the United Nations was represented by Miss Margaret J. Anstee, Under-Secretary-General, Director-General of the United Nations Office at Vienna. Mr. Francisco Ramos-Galino, Director of the Division of Narcotic Drugs, was appointed by the Secretary-General as Executive Secretary.

18. The Conference had before it the report of the Review Group convened pursuant to Economic and Social Council resolution 1988/8 of 25 May 1988 (E/CONF.82/3). In addition to an account of the work of the Review Group, the report contained proposals submitted to the Review Group relating to the draft Convention for consideration by the Conference, and the text of the draft Convention against Illicit Traffic in Narcotic Drugs and Psychotropic Substances (annex II). This draft Convention constituted the basic proposal for consideration by the Conference.

19. The Conference in the course of its work divided the articles contained in the draft Convention between the two Committees of the Whole (Committee I and Committee II). Articles 1 to 5 and the preamble were referred to Committee I and the remaining articles to Committee II. The Committees of 
the Whole, after agreeing upon the text of a particular article, referred it to the Drafting Committee. The Committees of the Whole reported to the Conference on the outcome of their work and the Drafting Committee submitted to the Conference a complete text of the draft Convention against Illicit Traffic in Narcotic Drugs and Psychotropic Substances (E/CONF.82/13).

20. On the basis of the deliberations set forth in the records of the Conference (E/CONF.82/SR.1 to 8) and of the Committees of the Whole (E/CONF.82/C.1/SR.1 to 33 and E/CONF.82/C.2/SR.1 to 34) and the reports of the Committees of the Whole (E/CONF.82/11 and E/CONF.82/12) and the Drafting Committee (E/CONF.82/13), the Conference drew up the following Convention:

United Nations Convention against Illicit Traffic in Narcotic Drugs and Psychotropic Substances.

21. The foregoing Convention, which is subject to ratification, acceptance, approval or act of formal confirmation, and which shall remain open for accession, was adopted by the Conference on 19 December 1988 and opened for signature on 20 December 1988, in accordance with its provisions, until 28 February 1989 at the United Nations Office at Vienna and, subsequently, until 20 December 1989, at the Headquarters of the United Nations at New York, the Secretary-General of the United Nations being the depositary.

22. The Conference also adopted the following resolutions, which are annexed to this Final Act:

1. Exchange of information

2. Provisional application of the United Nations Convention against Illicit Traffic in Narcotic Drugs and Psychotropic Substances

3. Provision of necessary resources to the Division of Narcotic Drugs and the secretariat of the International Narcotics Control Board to enable them to discharge the tasks entrusted to them under the International Drug Control Treaties

IN WITNESS WHEREOF the representatives have signed this Final Act.

DONE AT VIENNA this twentieth day of December one thousand nine hundred and eighty-eight, in a single copy, which will be deposited with the 
Secretary-General of the United Nations, in the Arabic, Chinese, English, French, Russian and Spanish languages, each text being equally authentic. 


\title{
Resolutions adopted by the United Nations Conference for the Adoption of a Convention against Illicit Traffic in Narcotic Drugs and Psychotropic Substances
}

\author{
Resolution 1 \\ Exchange of Information
}

The United Nations Conference for the Adoption of a Convention against Illicit Traffic in Narcotic Drugs and Psychotropic Substances,

Calling attention to resolution III adopted by the 1961 United Nations Conference for the Adoption of a Single Convention on Narcotic Drugs, in which attention was drawn to the importance of the technical records on international drug traffickers of the International Criminal Police Organization and their use by that organization for the circulation of descriptions of such traffickers,

Considering the machinery developed by the International Criminal Police Organization for the timely and efficient exchange of crime investigation information between police authorities on a worldwide basis,

Recommends that the widest possible use should be made by police authorities of the records and communications system of the International Criminal Police Organization in achieving the goals of the United Nations Convention against Illicit Traffic in Narcotic Drugs and Psychotropic Substances.

\section{Resolution 2}

Provisional application of the United Nations Convention against Illicit Traffic In Narcotic Drugs and Psychotropic Substances

The United Nations Conference for the Adoption of a Convention against Illicit Traffic in Narcotic Drugs and Psychotropic Substances,

1. Urges States, to the extent that they are able to do so, to accelerate steps to ratify the United Nations Convention against Illicit Traffic in Narcotic 
Drugs and Psychotropic Substances so that it enters into force as quickly as possible;

2. Invites States, to the extent that they are able to do so, to apply provisionally the measures provided in the Convention pending its entry into force for each of them;

3. Requests the Secretary-General to transmit the present resolution to the Economic and Social Council and the General Assembly.

\section{Resolution 3.}

Provision of necessary resources to the Division of Narcotic Drugs and the secretariat of the International Narcotics Control Board to enable them to discharge the tasks entrusted to them under the International Drug Control Treaties

The United Nations Conference for the Adoption of a Convention against Illicit Traffic in Narcotic Drugs and Psychotropic Substances,

Recognizing that the Single Convention on Narcotic Drugs, 1961, that Convention as amended by the 1972 Protocol Amending the Single Convention on Narcotic Drugs, 1961, and the Convention on Psychotropic Substances, 1971, remain the basis for international efforts in the control of narcotic drugs and psychotropic substances, and that strict implementation both by Governments and by the international control organs of the United Nations of the obligations arising from the Conventions is essential to achieve their aims,

Considering that the United Nations Convention against Illicit Traffic in Narcotic Drugs and Psychotropic Substances will create further obligations and financial outlays for Governments, the Commission on Narcotic Drugs, the International Narcotics Control Board and their secretariats,

Deeply disturbed by the impact of recent staffing and budgetary reductions on the capacity of both the Division of Narcotic Drugs and the secretariat of the International Narcotics Control Board to carry out fully their mandated programme of work, 
1. Urges all Member States to take appropriate steps in the General Assembly as well as in the financial organs of the Assembly to assign the appropriate priority and approve the necessary budgetary appropriations with a view to providing the Division of Narcotic Drugs and the secretariat of the International Narcotics Control Board with the necessary resources to discharge fully the tasks entrusted to them under the United Nations Convention against Illicit Traffic in Narcotic Drugs and Psychotropic Substances, the Single Convention on Narcotic Drugs, 1961, that Convention as amended by the 1972 Protocol Amending the Single Convention on Narcotic Drugs, 1961, and the Convention on Psychotropic Substances, 1971;

2. Requests the Secretary-General to take the necessary steps, within his competence, to give effect to the provisions of paragraph 1 above. 



\section{United Nations Convention against Illicit Traffic in Narcotic Drugs and Psychotropic Substances}

\section{The Parties to this Convention,}

Deeply concerned by the magnitude of and rising trend in the illicit production of, demand for and traffic in narcotic drugs and psychotropic substances, which pose a serious threat to the health and welfare of human beings and adversely affect the economic, cultural and political foundations of society,

Deeply concerned also by the steadily increasing inroads into various social groups made by illicit traffic in narcotic drugs and psychotropic substances, and particularly by the fact that children are used in many parts of the world as an illicit drug consumers market and for purposes of illicit production, distribution and trade in narcotic drugs and psychotropic substances, which entails a danger of incalculable gravity,

Recognizing the links between illicit traffic and other related organized criminal activities which undermine the legitimate economies and threaten the stability, security and sovereignty of States,

Recognizing also that illicit traffic is an international criminal activity, the suppression of which demands urgent attention and the highest priority,

Aware that illicit traffic generates large financial profits and wealth enabling transnational criminal organizations to penetrate, contaminate and corrupt the structures of government, legitimate commercial and financial business, and society at all its levels,

Determined to deprive persons engaged in illicit traffic of the proceeds of their criminal activities and thereby eliminate their main incentive for so doing, 
Desiring to eliminate the root causes of the problem of abuse of narcotic drugs and psychotropic substances, including the illicit demand for such drugs and substances and the enormous profits derived from illicit traffic,

Considering that measures are necessary to monitor certain substances, including precursors, chemicals and solvents, which are used in the manufacture of narcotic drugs and psychotropic substances, the ready availability of which has led to an increase in the clandestine manufacture of such drugs and substances,

Determined to improve international co-operation in the suppression of illicit traffic by sea,

Recognizing that eradication of illicit traffic is a collective responsibility of all States and that, to that end, co-ordinated action within the framework of international co-operation is necessary,

Acknowledging the competence of the United Nations in the field of control of narcotic drugs and psychotropic substances and desirous that the international organs concerned with such control should be within the framework of that Organization,

Reaffirming the guiding principles of existing treaties in the field of narcotic drugs and psychotropic substances and the system of control which they embody,

Recognizing the need to reinforce and supplement the measures provided in the Single Convention on Narcotic Drugs, 1961, that Convention as amended by the 1972 Protocol Amending the Single Convention on Narcotic Drugs, 1961, and the 1971 Convention on Psychotropic Substances, in order to counter the magnitude and extent of illicit traffic and its grave consequences,

Recognizing also the importance of strengthening and enhancing effective legal means for international co-operation in criminal matters for suppressing the international criminal activities of illicit traffic,

Desiring to conclude a comprehensive, effective and operative international convention that is directed specifically against illicit traffic and that considers the various aspects of the problem as a whole, in particular those aspects not envisaged in the existing treaties in the field of narcotic drugs and psychotropic substances, 
Hereby agree as follows:

\section{Article 1. Definitions}

Except where otherwise expressly indicated or where the context otherwise requires, the following definitions shall apply throughout this Convention:

(a) "Board" means the International Narcotics Control Board established by the Single Convention on Narcotic Drugs, 1961, and that Convention as amended by the 1972 Protocol Amending the Single Convention on Narcotic Drugs, 1961;

(b) "Cannabis plant" means any plant of the genus Cannabis;

(c) "Coca bush" means the plant of any species of the genus Erythroxylon;

(d) "Commercial carrier" means any person or any public, private or other entity engaged in transporting persons, goods or mails for remuneration, hire or any other benefit;

(e) "Commission" means the Commission on Narcotic Drugs of the Economic and Social Council of the United Nations;

(f) "Confiscation", which includes forfeiture where applicable, means the permanent deprivation of property by order of a court or other competent authority;

(g) "Controlled delivery" means the technique of allowing illicit or suspect consignments of narcotic drugs, psychotropic substances, substances in Table I and Table II annexed to this Convention, or substances substituted for them, to pass out of, through or into the territory of one or more countries, with the knowledge and under the supervision of their competent authorities, with a view to identifying persons involved in the commission of offences established in accordance with article 3, paragraph 1, of the Convention;

(b) "1961 Convention" means the Single Convention on Narcotic Drugs, 1961;

(i) "1961 Convention as amended" means the Single Convention on Narcotic Drugs, 1961, as amended by the 1972 Protocol Amending the Single Convention on Narcotic Drugs, 1961; 
(j) "1971 Convention" means the Convention on Psychotropic Substances, 1971;

(k) "Council" means the Economic and Social Council of the United Nations;

(l) "Freezing" or "seizure" means temporarily prohibiting the transfer, conversion, disposition or movement of property or temporarily assuming custody or control of property on the basis of an order issued by a court or a competent authority;

(m) "Illicit traffic" means the offences set forth in article 3, paragraphs 1 and 2, of this Convention;

(n) "Narcotic drug" means any of the substances, natural or synthetic, in Schedules I and II of the Single Convention on Narcotic Drugs, 1961, and that Convention as amended by the 1972 Protocol Amending the Single Convention on Narcotic Drugs, 1961;

(o) "Opium poppy" means the plant of the species Papaver somniferum L;

(p) "Proceeds" means any property derived from or obtained, directly or indirectly, through the commission of an offence established in accordance with article 3, paragraph 1 ;

(q) "Property" means assets of every kind, whether corporeal or incorporeal, movable or immovable, tangible or intangible, and legal documents or instruments evidencing title to, or interest in, such assets;

(r) "Psychotropic substance" means any substance, natural or synthetic, or any natural material in Schedules I, II, III and IV of the Convention on Psychotropic Substances, 1971;

(s) "Secretary-General" means the Secretary-General of the United Nations;

(t) "Table I" and "Table II" mean the correspondingly numbered lists of substances annexed to this Convention, as amended from time to time in accordance with article 12 ,

(u) "Transit State" means a State through the territory of which illicit narcotic drugs, psychotropic substances and substances in Table I and Table II 
are being moved, which is neither the place of origin nor the place of ultimate destination thereof.

\section{Article 2. Scope of the Convention}

1. The purpose of this Convention is to promote co-operation among the Parties so that they may address more effectively the various aspects of illicit traffic in narcotic drugs and psychotropic substances having an international dimension. In carrying out their obligations under the Convention, the Parties shall take necessary measures, including legislative and administrative measures, in conformity with the fundamental provisions of their respective domestic legislative systems.

2. The Parties shall carry out their obligations under this Convention in a manner consistent with the principles of sovereign equality and territorial integrity of States and that of non-intervention in the domestic affairs of other States.

3. A Party shall not undertake in the territory of another Party the exercise of jurisdiction and performance of functions which are exclusively reserved for the authorities of that other Party by its domestic law.

\section{Article 3. Offences and sanctions}

1. Each Party shall adopt such measures as may be necessary to establish as criminal offences under its domestic law, when committed intentionally:

(a) (i) The production, manufacture, extraction; preparation, offering, offering for sale, distribution, sale, delivery on any terms whatsoever, brokerage, dispatch, dispatch in transit, transport, importation or exportation of any narcotic drug or any psychotropic substance contrary to the provisions of the 1961 Convention, the 1961 Convention as amended or the 1971 Convention;

(ii) The cultivation of opium poppy, coca bush or cannabis plant for the purpose of the production of narcotic drugs contrary to the provisions of the 1961 Convention and the 1961 Convention as amended; 
(iii) The possession or purchase of any narcotic drug or psychotropic substance for the purpose of any of the activities enumerated in (i) above;

(iv) The manufacture, transport or distribution of equipment, materials or of substances listed in Table I and Table II, knowing that they are to be used in or for the illicit cultivation, production or manufacture of narcotic drugs or psychotropic substances;

(v) The organization, management or financing of any of the offences enumerated in (i), (ii), (iii) or (iv) above;

(b) (i) The conversion or transfer of property, knowing that such property is derived from any offence or offences established in accordance with subparagraph (a) of this paragraph, or from an act of participation in such offence or offences, for the purpose of concealing or disguising the illicit origin of the property or of assisting any person who is involved in the commission of such an offence or offences to evade the legal consequences of his actions;

(ii) The concealment or disguise of the true nature, source, location, disposition, movement, rights with respect to, or ownership of property, knowing that such property is derived from an offence or offences established in accordance with subparagraph (a) of this paragraph or from an act of participation in such an offence or offences;

(c) Subject to its constitutional principles and the basic concepts of its legal system:

(i) The acquisition, possession or use of property, knowing, at the time of receipt, that such property was derived from an offence or offences established in accordance with subparagraph (a) of this paragraph or from an act of participation in such offence or offences;

(ii) The possession of equipment or materials or substances listed in Table I and Table II, knowing that they are being or are to be used in or for the illicit cultivation, production or manufacture of narcotic drugs or psychotropic substances;

(iii) Publicly inciting or inducing others, by any means, to commit any of the offences established in accordance with this article or 
to use narcotic drugs or psychotropic substances illicitly;

(iv) Participation in, association or conspiracy to commit, attempts to commit and aiding, abetting, facilitating and counselling the commission of any of the offences established in accordance with this article.

2. Subject to its constitutional principles and the basic concepts of its legal system, each Party shall adopt such measures as may be necessary to establish as a criminal offence under its domestic law, when committed intentionally, the possession, purchase or cultivation of narcotic drugs or psychotropic substances for personal consumption contrary to the provisions of the 1961 Convention, the 1961 Convention as amended or the 1971 Convention.

3. Knowledge, intent or purpose required as an element of an offence set forth in paragraph 1 of this article may be inferred from objective factual circumstances.

4. (a) Each Party shall make the commission of the offences established in accordance with paragraph 1 of this article liable to sanctions which take into account the grave nature of these offences, such as imprisonment or other forms of deprivation of liberty, pecuniary sanctions and confiscation.

(b) The Parties may provide, in addition to conviction or punishment, for an offence established in accordance with paragraph 1 of this article, that the offender shall undergo measures such as treatment, education, aftercare, rehabilitation or social reintegration.

(c) Notwithstanding the preceding subparagraphs, in appropriate cases of a minor nature, the Parties may provide, as alternatives to conviction or punishment, measures such as education, rehabilitation or social reintegration, as well as, when the offender is a drug abuser, treatment and aftercare.

(d) The Parties may provide, either as an alternative to conviction or punishment, or in addition to conviction or punishment of an offence established in accordance with paragraph 2 of this article, measures for the treatment, education, aftercare, rehabilitation or social reintegration of the offender.

5. The Parties shall ensure that their courts and other competent authorities having jurisdiction can take into account factual circumstances which make 
the commission of the offences established in accordance with paragraph 1 of this article particularly serious, such as:

(a) The involvement in the offence of an organized criminal group to which the offender belongs;

(b) The involvement of the offender in other international organized criminal activities;

(c) The involvement of the offender in other illegal activities facilitated by commission of the offence;

(d) The use of violence or arms by the offender;

(e) The fact that the offender holds a public office and that the offence is connected with the office in question;

(f) The victimization or use of minors;

(g) The fact that the offence is committed in a penal institution or in an educational institution or social service facility or in their immediate vicinity or in other places to which school children and students resort for educational, sports and social activities;

(b) Prior conviction, particularly for similar offences, whether foreign or domestic, to the extent permitted under the domestic law of a Party.

6. The Parties shall endeavour to ensure that any discretionary legal powers under their domestic law relating to the prosecution of persons for offences established in accordance with this article are exercised to maximize the effectiveness of law enforcement measures in respect of those offences and with due regard to the need to deter the commission of such offences.

7. The Parties shall ensure that their courts or other competent authorities bear in mind the serious nature of the offences enumerated in paragraph 1 of this article and the circumstances enumerated in paragraph 5 of this article when considering the eventuality of early release or parole of persons convicted of such offences.

8. Each Party shall, where appropriate, establish under its domestic law a long statute of limitations period in which to commence proceedings for any offence established in accordance with paragraph 1 of this article, and a longer period where the alleged offender has evaded the administration of justice. 
9. Each Party shall take appropriate measures, consistent with its legal system, to ensure that a person charged with or convicted of an offence established in accordance with paragraph 1 of this article, who is found within its territory, is present at the necessary criminal proceedings.

10. For the purpose of co-operation among the Parties under this Convention, including, in particular, co-operation under articles 5, 6, 7 and 9, offences established in accordance with this article shall not be considered as fiscal offences or as political offences or regarded as politically motivated, without prejudice to the constitutional limitations and the fundamental domestic law of the Parties.

11. Nothing contained in this article shall affect the principle that the description of the offences to which it refers and of legal defences thereto is reserved to the domestic law of a Party and that such offences shall be prosecuted and punished in conformity with that law.

\section{Article 4. Jurisdiction}

1. Each Party:

(a) Shall take such measures as may be necessary to establish its jurisdiction over the offences it has established in accordance with article 3, paragraph 1, when:

(i) The offence is committed in its territory;

(ii) The offence is committed on board a vessel flying its flag or an aircraft which is registered under its laws at the time the offence is committed;

(b) May take such measures as maybe necessary to establish its jurisdiction over the offences it has established in accordance with article 3, paragraph 1, when:

(i) The offence is committed by one of its nationals or by a person who has his habitual residence in its territory;

(ii) The offence is committed on board a vessel concerning which that Party has been authorized to take appropriate action pursuant to article 17, provided that such jurisdiction shall be exercised 
only on the basis of agreements or arrangements referred to in paragraphs 4 and 9 of that article;

(iii) The offence is one of those established in accordance with article 3, paragraph 1, subparagraph (c) (iv), and is committed outside its territory with a view to the commission, within its territory, of an offence established in accordance with article 3, paragraph 1.

2. Each Party:

(a) Shall also take such measures as may be necessary to establish its jurisdiction over the offences it has established in accordance with article 3, paragraph 1, when the alleged offender is present in its territory and it does not extradite him to another Party on the ground:

(i) That the offence has been committed in its territory or on board a vessel flying its flag or an aircraft which was registered under its law at the time the offence was committed; or

(ii) That the offence has been committed by one of its nationals;

(b) May also take such measures as may be necessary to establish its jurisdiction over the offences it has established in accordance with article 3, paragraph 1 , when the alleged offender is present in its territory and it does not extradite him to another Party.

3. This Convention does not exclude the exercise of any criminal jurisdiction established by a Party in accordance with its domestic law.

\section{Article 5. Confiscation}

1. Each Party shall adopt such measures as may be necessary to enable confiscation of:

(a) Proceeds derived from offences established in accordance with article 3, paragraph 1 , or property the value of which corresponds to that of such proceeds;

(b) Narcotic drugs and psychotropic substances, materials and equipment or other instrumentalities used in or intended for use in any manner in offences established in accordance with article 3, paragraph 1. 
2. Each Party shall also adopt such measures as may be necessary to enable its competent authorities to identify, trace, and freeze or seize proceeds, property, instrumentalities or any other things referred to in paragraph 1 of this article, for the purpose of eventual confiscation.

3. In order to carry out the measures referred to in this article, each Party shall empower its courts or other competent authorities to order that bank, financial or commercial records be made available or be seized. A Party shall not decline to act under the provisions of this paragraph on the ground of bank secrecy.

4. (a) Following a request made pursuant to this article by another Party having jurisdiction over an offence established in accordance with article 3 , paragraph 1, the Party in whose territory proceeds, property, instrumentalities or any other things referred to in paragraph 1 of this article are situated shall:

(i) Submit the request to its competent authorities for the purpose of obtaining an order of confiscation and, if such order is granted, give effect to it; or

(ii) Submit to its competent authorities, with a view to giving effect to it to the extent requested, an order of confiscation issued by the requesting Party in accordance with paragraph 1 of this article, in so far as it relates to proceeds, property, instrumentalities or any other things referred to in paragraph 1 situated in the territory of the requested Party.

(b) Following a request made pursuant to this article by another Party having jurisdiction over an offence established in accordance with article 3, paragraph 1, the requested Party shall take measures to identify, trace, and freeze or seize proceeds, property, instrumentalities or any other things referred to in paragraph 1 of this article for the purpose of eventual confiscation to be ordered either by the requesting Party or, pursuant to a request under subparagraph (a) of this paragraph, by the requested Party.

(c) The decisions or actions provided for in subparagraphs (a) and (b) of this paragraph shall be taken by the requested Party, in accordance with and subject to the provisions of its domestic law and its procedural rules or any bilateral or multilateral treaty, agreement or arrangement to which it may be bound in relation to the requesting Party. 
(d) The provisions of article 7, paragraphs 6 to 19 are applicable mutatis mutandis. In addition to the information specified in article 7, paragraph 10, requests made pursuant to this article shall contain the following:

(i) In the case of a request pertaining to subparagraph (a) (i) of this paragraph, a description of the property to be confiscated and a statement of the facts relied upon by the requesting Party sufficient to enable the requested Party to seek the order under its domestic law;

(ii) In the case of a request pertaining to subparagraph (a) (ii), a legally admissible copy of an order of confiscation issued by the requesting Party upon which the request is based, a statement of the facts and information as to the extent to which the execution of the order is requested;

(iii) In the case of a request pertaining to subparagraph (b), a statement of the facts relied upon by the requesting Party and a description of the actions requested.

(e) Each Party shall furnish to the Secretary-General the text of any of its laws and regulations which give effect to this paragraph and the text of any subsequent changes to such laws and regulations.

(f) If a Party elects to make the taking of the measures referred to in subparagraphs (a) and (b) of this paragraph conditional on the existence of a relevant treaty, that Party shall consider this Convention as the necessary and sufficient treaty basis.

(g) The Parties shall seek to conclude bilateral and multilateral treaties, agreements or arrangements to enhance the effectiveness of international cooperation pursuant to this article.

5. (a) Proceeds or property confiscated by a Party pursuant to paragraph 1 or paragraph 4 of this article shall be disposed of by that Party according to its domestic law and administrative procedures.

(b) When acting on the request of another Party in accordance with this article, a Party may give special consideration to concluding agreements on:

(i) Contributing the value of such proceeds and property, or funds derived from the sale of such proceeds or property, or a substantial 
part thereof, to intergovernmental bodies specializing in the fight against illicit traffic in and abuse of narcotic drugs and psychotropic substances;

(ii) Sharing with other Parties, on a regular or case-by-case basis, such proceeds or property, or funds derived from the sale of such proceeds or property, in accordance with its domestic law, administrative procedures or bilateral or multilateral agreements entered into for this purpose.

6. (a) If proceeds have been transformed or converted into other property, such property shall be liable to the measures referred to in this article instead of the proceeds.

(b) If proceeds have been intermingled with property acquired from legitimate sources, such property shall, without prejudice to any powers relating to seizure or freezing, be liable to confiscation up to the assessed value of the intermingled proceeds.

(c) Income or other benefits derived from:

(i) Proceeds;

(ii) Property into which proceeds have been transformed or converted; or

(iii) Property with which proceeds have been intermingled

shall also be liable to the measures referred to in this article, in the same manner and to the same extent as proceeds.

7. Each Party may consider ensuring that the onus of proof be reversed regarding the lawful origin of alleged proceeds or other property liable to confiscation, to the extent that such action is consistent with the principles of its domestic law and with the nature of the judicial and other proceedings.

8. The provisions of this article shall not be construed as prejudicing the rights of bona fide third parties.

9. Nothing contained in this article shall affect the principle that the measures to which it refers shall be defined and implemented in accordance with and subject to the provisions of the domestic law of a Party. 


\section{Article 6. Extradition}

1. This article shall apply to the offences established by the Parties in accordance with article 3, paragraph 1 .

2. Each of the offences to which this article applies shall be deemed to be included as an extraditable offence in any extradition treaty existing between Parties. The Parties undertake to include such offences as extraditable offences in every extradition treaty to be concluded between them.

3. If a Party which makes extradition conditional on the existence of a treaty receives a request for extradition from another Party with which it has no extradition treaty, it may consider this Convention as the legal basis for extradition in respect of any offence to which this article applies. The Parties which require detailed legislation in order to use this Convention as a legal basis for extradition shall consider enacting such legislation as may be necessary.

4. The Parties which do not make extradition conditional on the existence of a treaty shall recognize offences to which this article applies as extraditable offences between themselves.

5. Extradition shall be subject to the conditions provided for by the law of the requested Party or by applicable extradition treaties, including the grounds upon which the requested Party may refuse extradition.

6. In considering requests received pursuant to this article, the requested State may refuse to comply with such requests where there are substantial grounds leading its judicial or other competent authorities to believe that compliance would facilitate the prosecution or punishment of any person on account of his race, religion, nationality or political opinions, or would cause prejudice for any of those reasons to any person affected by the request.

7. The Parties shall endeavour to expedite extradition procedures and to simplify evidentiary requirements relating thereto in respect of any offence to which this article applies.

8. Subject to the provisions of its domestic law and its extradition treaties, the requested Party may, upon being satisfied that the circumstances so warrant and are urgent, and at the request of the requesting Party, take a person 
whose extradition is sought and who is present in its territory into custody or take other appropriate measures to ensure his presence at extradition proceedings.

9. Without prejudice to the exercise of any criminal jurisdiction established in accordance with its domestic law, a Party in whose territory an alleged offender is found shall:

(a) If it does not extradite him in respect of an offence established in accordance with article 3, paragraph 1 , on the grounds set forth in article 4, paragraph 2, subparagraph (a), submit the case to its competent authorities for the purpose of prosecution, unless otherwise agreed with the requesting Party;

(b) If it does not extradite him in respect of such an offence and has established its jurisdiction in relation to that offence in accordance with article 4, paragraph 2, subparagraph (b), submit the case to its competent authorities for the purpose of prosecution, unless otherwise requested by the requesting Party for the purposes of preserving its legitimate jurisdiction.

10. If extradition, sought for purposes of enforcing a sentence, is refused because the person sought is a national of the requested Party, the requested Party shall, if its law so permits and in conformity with the requirements of such law, upon application of the requesting Party, consider the enforcement of the sentence which has been imposed under the law of the requesting Party, or the remainder thereof.

11. The Parties shall seek to conclude bilateral and multilateral agreements to carry out or to enhance the effectiveness of extradition.

12. The Parties may consider entering into bilateral or multilateral agreements, whether ad hoc or general, on the transfer to their country of persons sentenced to imprisonment and other forms of deprivation of liberty for offences to which this article applies, in order that they may complete their sentences there.

\section{Article 7. Mutual legal assistance}

1. The Parties shall afford one another, pursuant to this article, the widest measure of mutual legal assistance in investigations, prosecutions and judicial proceedings in relation to criminal offences established in accordance with article 3, paragraph 1 . 
2. Mutual legal assistance to be afforded in accordance with this article may be requested for any of the following purposes:

(a) Taking evidence or statements from persons;

(b) Effecting service of judicial documents;

(c) Executing searches and seizures;

(d) Examining objects and sites;

(e) Providing information and evidentiary items;

(f) Providing originals or certified copies of relevant documents and records, including bank, financial, corporate or business records;

(g) Identifying or tracing proceeds, property, instrumentalities or other things for evidentiary purposes.

3. The Parties may afford one another any other forms of mutual legal assistance allowed by the domestic law of the requested Party.

4. Upon request, the Parties shall facilitate or encourage, to the extent consistent with their domestic law and practice, the presence or availability of persons, including persons in custody, who consent to assist in investigations or participate in proceedings.

5. A Party shall not decline to render mutual legal assistance under this article on the ground of bank secrecy.

6. The provisions of this article shall not affect the obligations under any other treaty, bilateral or multilateral, which governs or will govern, in whole or in part, mutual legal assistance in criminal matters.

7. Paragraphs 8 to 19 of this article shall apply to requests made pursuant to this article if the Parties in question are not bound by a treaty of mutual legal assistance. If these Parties are bound by such a treaty, the corresponding provisions of that treaty shall apply unless the Parties agree to apply paragraphs 8 to 19 of this article in lieu thereof.

8. Parties shall designate an authority, or when necessary authorities, which shall have the responsibility and power to execute requests for mutual 
legal assistance or to transmit them to the competent authorities for execution. The authority or the authorities designated for this purpose shall be notified to the Secretary-General. Transmission of requests for mutual legal assistance and any communication related thereto shall be effected between the authorities designated by the Parties; this requirement shall be without prejudice to the right of a Party to require that such requests and communications be addressed to it through the diplomatic channel and, in urgent circumstances, where the Parties agree, through channels of the International Criminal Police Organization, if possible.

9. Requests shall be made in writing in a language acceptable to the requested Party. The language or languages acceptable to each Party shall be notified to the Secretary-General. In urgent circumstances, and where agreed by the Parties, requests may be made orally, but shall be confirmed in writing forthwith.

10. A request for mutual legal assistance shall contain:

(a) The identity of the authority making the request;

(b) The subject matter and nature of the investigation, prosecution or proceeding to which the request relates, and the name and the functions of the authority conducting such investigation, prosecution or proceeding;

(c) A summary of the relevant facts, except in respect of requests for the purpose of service of judicial documents;

(d) A description of the assistance sought and details of any particular procedure the requesting Party wishes to be followed;

(e) Where possible, the identity, location and nationality of any person concerned;

(f) The purpose for which the evidence, information or action is sought.

11. The requested Party may request additional information when it appears necessary for the execution of the request in accordance with its domestic law or when it can facilitate such execution.

12. A request shall be executed in accordance with the domestic law of the requested Party and, to the extent not contrary to the domestic law of the requested Party and where possible, in accordance with the procedures specified in the request. 
13. The requesting Party shall not transmit nor use information or evidence furnished by the requested Party for investigations, prosecutions or proceedings other than those stated in the request without the prior consent of the requested Party.

14. The requesting Party may require that the requested Party keep confidential the fact and substance of the request, except to the extent necessary to execute the request. If the requested Party cannot comply with the requirement of confidentiality, it shall promptly inform the requesting Party.

15. Mutual legal assistance may be refused:

(a) If the request is not made in conformity with the provisions of this article;

(b) If the requested Party considers that execution of the request is likely to prejudice its sovereignty, security, ordre public or other essential interests;

(c) If the authorities of the requested Party would be prohibited by its domestic law from carrying out the action requested with regard to any similar offence, had it been subject to investigation, prosecution or proceedings under their own jurisdiction;

(d) If it would be contrary to the legal system of the requested Party relating to mutual legal assistance for the request to be granted.

16. Reasons shall be given for any refusal of mutual legal assistance.

17. Mutual legal assistance may be postponed by the requested Party on the ground that it interferes with an ongoing investigation, prosecution or proceeding. In such a case, the requested Party shall consult with the requesting Party to determine if the assistance can still be given subject to such terms and conditions as the requested Party deems necessary.

18. A witness, expert or other person who consents to give evidence in a proceeding or to assist in an investigation, prosecution or judicial proceeding in the territory of the requesting Party, shall not be prosecuted, detained, punished or subjected to any other restriction of his personal liberty in that territory in respect of acts, omissions or convictions prior to his departure from the territory of the requested Party. Such safe conduct shall cease when the witness, expert 
or other person having had, for a period of fifteen consecutive days, or for any period agreed upon by the Parties, from the date on which he has been officially informed that his presence is no longer required by the judicial authorities, an opportunity of leaving, has nevertheless remained voluntarily in the territory or, having left it, has returned of his own free will.

19. The ordinary costs of executing a request shall be borne by the requested Party, unless otherwise agreed by the Parties concerned. If expenses of a substantial or extraordinary nature are or will be required to fulfil the request, the Parties shall consult to determine the terms and conditions under which the request will be executed as well as the manner in which the costs shall be borne.

20. The Parties shall consider, as may be necessary, the possibility of concluding bilateral or multilateral agreements or arrangements that would serve the purposes of, give practical effect to, or enhance the provisions of this article.

\section{Article 8. Transfer of proceedings}

The Parties shall give consideration to the possibility of transferring to one another proceedings for criminal prosecution of offences established in accordance with article 3, paragraph 1 , in cases where such transfer is considered to be in the interests of a proper administration of justice.

\section{Article 9. Other forms of co-operation and training}

1. The Parties shall co-operate closely with one another, consistent with their respective domestic legal and administrative systems, with a view to enhancing the effectiveness of law enforcement action to suppress the commission of offences established in accordance with article 3, paragraph 1 . They shall, in particular, on the basis of bilateral or multilateral agreements or arrangements:

(a) Establish and maintain channels of communication between their competent agencies and services to facilitate the secure and rapid exchange of information concerning all aspects of offences established in accordance with article 3, paragraph 1, including, if the Parties concerned deem it appropriate, links with other criminal activities; 
(b) Co-operate with one another in conducting enquiries, with respect to offences established in accordance with article 3, paragraph 1, having an international character, concerning:

(i) The identity, whereabouts and activities of persons suspected of being involved in offences established in accordance with article 3, paragraph 1;

(ii) The movement of proceeds or property derived from the commission of such offences;

(iii) The movement of narcotic drugs, psychotropic substances, substances in Table I and Table II of this Convention and instrumentalities used or intended for use in the commission of such offences;

(c) In appropriate cases and if not contrary to domestic law, establish joint teams, taking into account the need to protect the security of persons and of operations, to carry out the provisions of this paragraph. Officials of any Party taking part in such teams shall act as authorized by the appropriate authorities of the Party in whose territory the operation is to take place; in all such cases, the Parties involved shall ensure that the sovereignty of the Party on whose territory the operation is to take place is fully respected;

(d) Provide, when appropriate, necessary quantities of substances for analytical or investigative purposes;

(e) Facilitate effective co-ordination between their competent agencies and services and promote the exchange of personnel and other experts, including the posting of liaison officers.

2. Each Party shall, to the extent necessary, initiate, develop or improve specific training programmes for its law enforcement and other personnel, including customs, charged with the suppression of offences established in accordance with article 3, paragraph 1 . Such programmes shall deal, in particular, with the following:

(a) Methods used in the detection and suppression of offences established in accordance with article 3, paragraph 1;

(b) Routes and techniques used by persons suspected of being involved in offences established in accordance with article 3, paragraph 1, particularly in transit States, and appropriate countermeasures; 
(c) Monitoring of the import and export of narcotic drugs, psychotropic substances and substances in Table I and Table II;

(d) Detection and monitoring of the movement of proceeds and property derived from, and narcotic drugs, psychotropic substances and substances in Table I and Table II, and instrumentalities used or intended for use in, the commission of offences established in accordance with article 3, paragraph 1;

(e) Methods used for the transfer, concealment or disguise of such proceeds, property and instrumentalities;

(f) Collection of evidence;

(g) Control techniques in free trade zones and free ports;

(b) Modern law enforcement techniques.

3. The Parties shall assist one another to plan and implement research and training programmes designed to share expertise in the areas referred to in paragraph 2 of this article and, to this end, shall also, when appropriate, use regional and international conferences and seminars to promote co-operation and stimulate discussion on problems of mutual concern, including the special problems and needs of transit States.

\section{Article 10. International co-operation and assistance for transit States}

1. The Parties shall co-operate, directly or through competent international or regional organizations, to assist and support transit States and, in particular, developing countries in need of such assistance and support, to the extent possible, through programmes of technical co-operation on interdiction and other related activities.

2. The Parties may undertake, directly or through competent international or regional organizations, to provide financial assistance to such transit States for the purpose of augmenting and strengthening the infrastructure needed for effective control and prevention of illicit traffic.

3. The Parties may conclude bilateral or multilateral agreements or arrangements to enhance the effectiveness of international co-operation pursuant to this article and may take into consideration financial arrangements in this regard. 


\section{Article 11. Controlled delivery}

1. If permitted by the basic principles of their respective domestic legal systems, the Parties shall take the necessary measures, within their possibilities, to allow for the appropriate use of controlled delivery at the international level, on the basis of agreements or arrangements mutually consented to, with a view to identifying persons involved in offences established in accordance with article 3, paragraph 1, and to taking legal action against them.

2. Decisions to use controlled delivery shall be made on a case-by-case basis and may, when necessary, take into consideration financial arrangements and understandings with respect to the exercise of jurisdiction by the Parties concerned.

3. Illicit consignments whose controlled delivery is agreed to may, with the consent of the Parties concerned, be intercepted and allowed to continue with the narcotic drugs or psychotropic substances intact or removed or replaced in whole or in part.

\section{Article 12. Substances frequently used in the illicit manufacture of narcotic drugs or psychotropic substances}

1. The Parties shall take the measures they deem appropriate to prevent diversion of substances in Table I and Table II used for the purpose of illicit manufacture of narcotic drugs or psychotropic substances, and shall co-operate with one another to this end.

2. If a Party or the Board has information which in its opinion may require the inclusion of a substance in Table I or Table II, it shall notify the Secretary-General and furnish him with the information in support of that notification. The procedure described in paragraphs 2 to 7 of this article shall also apply when a Party or the Board has information justifying the deletion of a substance from Table I or Table II, or the transfer of a substance from one Table to the other.

3. The Secretary-General shall transmit such notification, and any information which he considers relevant, to the Parties, to the Commission, and, where notification is made by a Party, to the Board. The Parties shall communicate their comments concerning the notification to the Secretary-General, 
together with all supplementary information which may assist the Board in establishing an assessment and the Commission in reaching a decision.

4. If the Board, taking into account the extent, importance and diversity of the licit use of the substance, and the possibility and ease of using alternate substances both for licit purposes and for the illicit manufacture of narcotic drugs or psychotropic substances, finds:

(a) That the substance is frequently used in the illicit manufacture of a narcotic drug or psychotropic substance;

(b) That the volume and extent of the illicit manufacture of a narcotic drug or psychotropic substance creates serious public health or social problems, so as to warrant international action,

it shall communicate to the Commission an assessment of the substance, including the likely effect of adding the substance to either Table I or Table II on both licit use and illicit manufacture, together with recommendations of monitoring measures, if any, that would be appropriate in the light of its assessment.

5. The Commission, taking into account the comments submitted by the Parties and the comments and recommendations of the Board, whose assessment shall be determinative as to scientific matters, and also taking into due consideration any other relevant factors, may decide by a two-thirds majority of its members to place a substance in Table I or Table II.

6. Any decision of the Commission taken pursuant to this article shall be communicated by the Secretary-General to all States and other entities which are, or which are entitled to become, Parties to this Convention, and to the Board. Such decision shall become fully effective with respect to each Party one hundred and eighty days after the date of such communication.

7. (a) The decisions of the Commission taken under this article shall be subject to review by the Council upon the request of any Party filed within one hundred and eighty days after the date of notification of the decision. The request for review shall be sent to the Secretary-General, together with all relevant information upon which the request for review is based.

(b) The Secretary-General shall transmit copies of the request for review and the relevant information to the Commission, to the Board and to all the Parties, inviting them to submit their comments within ninety days. All comments received shall be submitted to the Council for consideration. 
(c) The Council may confirm or reverse the decision of the Commission. Notification of the Council's decision shall be transmitted to all States and other entities which are, or which are entitled to become, Parties to this Convention, to the Commission and to the Board.

8. (a) Without prejudice to the generality of the provisions contained in paragraph 1 of this article and the provisions of the 1961 Convention, the 1961 Convention as amended and the 1971 Convention, the Parties shall take the measures they deem appropriate to monitor the manufacture and distribution of substances in Table I and Table Il which are carried out within their territory.

(b) To this end, the Parties may:

(i) Control all persons and enterprises engaged in the manufacture and distribution of such substances;

(ii) Control under licence the establishment and premises in which such manufacture or distribution may take place;

(iii) Require that licensees obtain a permit for conducting the aforesaid operations;

(iv) Prevent the accumulation of such substances in the possession of manufacturers and distributors, in excess of the quantities required for the normal conduct of business and the prevailing market conditions.

9. Each Party shall, with respect to substances in Table I and Table II, take the following measures:

(a) Establish and maintain a system to monitor international trade in substances in Table I and Table II in order to facilitate the identification of suspicious transactions. Such monitoring systems shall be applied in close cooperation with manufacturers, importers, exporters, wholesalers and retailers, who shall inform the competent authorities of suspicious orders and transactions.

(b) Provide for the seizure of any substance in Table I or Table II if there is sufficient evidence that it is for use in the illicit manufacture of a narcotic drug or psychotropic substance. 
(c) Notify, as soon as possible, the competent authorities and services of the Parties concerned if there is reason to believe that the import, export or transit of a substance in Table I or Table II is destined for the illicit manufacture of narcotic drugs or psychotropic substances, including in particular information about the means of payment and any other essential elements which led to that belief.

(d) Require that imports and exports be properly labelled and documented. Commercial documents such as invoices, cargo manifests, customs, transport and other shipping documents shall include the names, as stated in Table I or Table II, of the substances being imported or exported, the quantity being imported or exported, and the name and address of the exporter, the importer and, when available, the consignee.

(e) Ensure that documents referred to in subparagraph (d) of this paragraph are maintained for a period of not less than two years and may be made available for inspection by the competent authorities.

10. (a) In addition to the provisions of paragraph 9, and upon request to the Secretary-General by the interested Party, each Party from whose territory a substance in Table I is to be exported shall ensure that, prior to such export, the following information is supplied by its competent authorities to the competent authorities of the importing country:

(i) Name and address of the exporter and importer and, when available, the consignee;

(ii) Name of the substance in Table I;

(iii) Quantity of the substance to be exported;

(iv) Expected point of entry and expected date of dispatch;

(v) Any other information which is mutually agreed upon by the Parties.

(b) A Party may adopt more strict or severe measures of control than those provided by this paragraph if, in its opinion, such measures are desirable or necessary.

11. Where a Party furnishes information to another Party in accordance with paragraphs 9 and 10 of this article, the Party furnishing such information may require that the Party receiving it keep confidential any trade, business, commercial or professional secret or trade process. 
12. Each Party shall furnish annually to the Board, in the form and manner provided for by it and on forms made available by it, information on:

(a) The amounts seized of substances in Table I and Table II and, when known, their origin;

(b) Any substance not included in Table I or Table II which is identified as having been used in illicit manufacture of narcotic drugs or psychotropic substances, and which is deemed by the Party to be sufficiently significant to be brought to the attention of the Board;

(c) Methods of diversion and illicit manufacture.

13. The Board shall report annually to the Commission on the implementation of this article and the Commission shall periodically review the adequacy and propriety of Table I and Table II.

14. The provisions of this article shall not apply to pharmaceutical preparations, nor to other preparations containing substances in Table I or Table II that are compounded in such a way that such substances cannot be easily used or recovered by readily applicable means.

\section{Article 13. Materials and equipment}

The Parties shall take such measures as they deem appropriate to prevent trade in and the diversion of materials and equipment for illicit production or manufacture of narcotic drugs and psychotropic substances and shall co-operate to this end.

Article 14. Measures to eradicate illicit cultivation of narcotic plants and to eliminate illicit demand for narcotic drugs and psychotropic substances

1. Any measures taken pursuant to this Convention by Parties shall not be less stringent than the provisions applicable to the eradication of illicit cultivation of plants containing narcotic and psychotropic substances and to the elimination of illicit demand for narcotic drugs and psychotropic substances under the provisions of the 1961 Convention, the 1961 Convention as amended and the 1971 Convention. 
2. Each Party shall take appropriate measures to prevent illicit cultivation of and to eradicate plants containing narcotic or psychotropic substances, such as opium poppy, coca bush and cannabis plants, cultivated illicitly in its territory. The measures adopted shall respect fundamental human rights and shall take due account of traditional licit uses, where there is historic evidence of such use, as well as the protection of the environment.

3. (a) The Parties may co-operate to increase the effectiveness of eradication efforts. Such co-operation may, inter alia, include support, when appropriate, for integrated rural development leading to economically viable alternatives to illicit cultivation. Factors such as access to markets, the availability of resources and prevailing socio-economic conditions should be taken into account before such rural development programmes are implemented. The Parties may agree on any other appropriate measures of co-operation.

(b) The Parties shall also facilitate the exchange of scientific and technical information and the conduct of research concerning eradication.

(c) Whenever they have common frontiers, the Parties shall seek to co-operate in eradication programmes in their respective areas along those frontiers.

4. The Parties shall adopt appropriate measures aimed at eliminating or reducing illicit demand for narcotic drugs and psychotropic substances, with a view to reducing human suffering and eliminating financial incentives for illicit traffic. These measures may be based, inter alia, on the recommendations of the United Nations, specialized agencies of the United Nations such as the World Health Organization, and other competent international organizations, and on the Comprehensive Multidisciplinary Outline adopted by the International Conference on Drug Abuse and Illicit Trafficking, held in 1987, as it pertains to governmental and non-governmental agencies and private efforts in the fields of prevention, treatment and rehabilitation. The Parties may enter into bilateral or multilateral agreements or arrangements aimed at eliminating or reducing illicit demand for narcotic drugs and psychotropic substances.

5. The Parties may also take necessary measures for early destruction or lawful disposal of the narcotic drugs, psychotropic substances and substances in Table I and Table II which have been seized or confiscated and for the admissibility as evidence of duly certified necessary quantities of such substances. 


\section{Article 15. Commercial carriers}

1. The Parties shall take appropriate measures to ensure that means of transport operated by commercial carriers are not used in the commission of offences established in accordance with article 3, paragraph 1; such measures may include special arrangements with commercial carriers.

2. Each Party shall require commercial carriers to take reasonable precautions to prevent the use of their means of transport for the commission of offences established in accordance with article 3, paragraph 1 . Such precautions may include:

(a) If the principal place of business of a commercial carrier is within the territory of the Party:

(i) Training of personnel to identify suspicious consignments or persons;

(ii) Promotion of integrity of personnel;

(b) If a commercial carrier is operating within the territory of the Party:

(i) Submission of cargo manifests in advance, whenever possible;

(ii) Use of tamper-resistant, individually verifiable seals on containers;

(iii) Reporting to the appropriate authorities at the earliest opportunity all suspicious circumstances that may be related to the commission of offences established in accordance with article 3, paragraph 1.

3. Each Party shall seek to ensure that commercial carriers and the appropriate authorities at points of entry and exit and other customs control areas co-operate, with a view to preventing unauthorized access to means of transport and cargo and to implementing appropriate security measures.

\section{Article 16. Commercial documents and labelling of exports}

1. Each Party shall require that lawful exports of narcotic drugs and psychotropic substances be properly documented. In addition to the requirements for documentation under article 31 of the 1961 Convention, article 31 
of the 1961 Convention as amended and article 12 of the 1971 Convention, commercial documents such as invoices, cargo manifests, customs, transport and other shipping documents shall include the names of the narcotic drugs and psychotropic substances being exported as set out in the respective Schedules of the 1961 Convention, the 1961 Convention as amended and the 1971 Convention, the quantity being exported, and the name and address of the exporter, the importer and, when available, the consignee.

2. Each Party shall require that consignments of narcotic drugs and psychotropic substances being exported be not mislabelled.

\section{Article 17. Illicit traffic by sea}

1. The Parties shall co-operate to the fullest extent possible to suppress illicit traffic by sea, in conformity with the international law of the sea.

2. A Party which has reasonable grounds to suspect that a vessel flying its flag or not displaying a flag or marks of registry is engaged in illicit traffic may request the assistance of other Parties in suppressing its use for that purpose. The Parties so requested shall render such assistance within the means available to them.

3. A Party which has reasonable grounds to suspect that a vessel exercising freedom of navigation in accordance with international law, and flying the flag or displaying marks of registry of another Party is engaged in illicit traffic may so notify the flag State, request confirmation of registry and, if confirmed, request authorization from the flag State to take appropriate measures in regard to that vessel.

4. In accordance with paragraph 3 or in accordance with treaties in force between them or in accordance with any agreement or arrangement otherwise reached between those Parties, the flag State may authorize the requesting State to, inter alia:

(a) Board the vessel;

(b) Search the vessel;

(c) If evidence of involvement in illicit traffic is found, take appropriate action with respect to the vessel, persons and cargo on board. 
5. Where action is taken pursuant to this article, the Parties concerned shall take due account of the need not to endanger the safety of life at sea, the security of the vessel and the cargo or to prejudice the commercial and legal interests of the flag State or any other interested State.

6. The flag State may, consistent with its obligations in paragraph 1 of this article, subject its authorization to conditions to be mutually agreed between it and the requesting Party, including conditions relating to responsibility.

7. For the purposes of paragraphs 3 and 4 of this article, a Party shall respond expeditiously to a request from another Party to determine whether a vessel that is flying its flag is entitled to do so, and to requests for authorization made pursuant to paragraph 3. At the time of becoming a Party to this Convention, each Party shall designate an authority or, when necessary, authorities to receive and respond to such requests. Such designation shall be notified through the Secretary-General to all other Parties within one month of the designation.

8. A Party which has taken any action in accordance with this article shall promptly inform the flag State concerned of the results of that action.

9. The Parties shall consider entering into bilateral or regional agreements or arrangements to carry out, or to enhance the effectiveness of, the provisions of this article.

10. Action pursuant to paragraph 4 of this article shall be carried out only by warships or military aircraft, or other ships or aircraft clearly marked and identifiable as being on government service and authorized to that effect.

11. Any action taken in accordance with this article shall take due account of the need not to interfere with or affect the rights and obligations and the exercise of jurisdiction of coastal States in accordance with the international law of the sea.

\section{Article 18. Free trade zones and free ports}

1. The Parties shall apply measures to suppress illicit traffic in narcotic drugs, psychotropic substances and substances in Table I and Table II in free 
trade zones and in free ports that are no less stringent than those applied in other parts of their territories.

2. The Parties shall endeavour:

(a) To monitor the movement of goods and persons in free trade zones and free ports, and, to that end, shall empower the competent authorities to search cargoes and incoming and outgoing vessels, including pleasure craft and fishing vessels, as well as aircraft and vehicles and, when appropriate, to search crew members, passengers and their baggage;

(b) To establish and maintain a system to detect consignments suspected of containing narcotic drugs, psychotropic substances and substances in Table I and Table II passing into or out of free trade zones and free ports;

(c) To establish and maintain surveillance systems in harbour and dock areas and at airports and border control points in free trade zones and free ports.

\section{Article 19. The use of the mails}

1. In conformity with their obligations under the Conventions of the Universal Postal Union, and in accordance with the basic principles of their domestic legal systems, the Parties shall adopt measures to suppress the use of the mails for illicit traffic and shall co-operate with one another to that end.

2. The measures referred to in paragraph 1 of this article shall include, in particular:

(a) Co-ordinated action for the prevention and repression of the use of the mails for illicit traffic;

(b) Introduction and maintenance by authorized law enforcement personnel of investigative and control techniques designed to detect illicit consignments of narcotic drugs, psychotropic substances and substances in Table I and Table II in the mails;

(c) Legislative measures to enable the use of appropriate means to secure evidence required for judicial proceedings. 


\section{Article 20. Information to be furnished by the Parties}

1. The Parties shall furnish, through the Secretary-General, information to the Commission on the working of this Convention in their territories and, in particular:

(a) The text of laws and regulations promulgated in order to give effect to the Convention;

(b) Particulars of cases of illicit traffic within their jurisdiction which they consider important because of new trends disclosed, the quantities involved, the sources from which the substances are obtained, or the methods employed by persons so engaged.

2. The Parties shall furnish such information in such a manner and by such dates as the Commission may request.

\section{Article 21. Functions of the Commission}

The Commission is authorized to consider all matters pertaining to the aims of this Convention and, in particular:

(a) The Commission shall, on the basis of the information submitted by the Parties in accordance with article 20, review the operation of this Convention;

(b) The Commission may make suggestions and general recommendations based on the examination of the information received from the Parties;

(c) The Commission may call the attention of the Board to any matters which may be relevant to the functions of the Board;

(d) The Commission shall, on any matter referred to it by the Board under article 22, paragraph 1 (b), take such action as it deems appropriate;

(e) The Commission may, in conformity with the procedures laid down in article 12, amend Table I and Table II;

(f) The Commission may draw the attention of non-Parties to decisions and recommendations which it adopts under this Convention, with a view to their considering taking action in accordance therewith. 


\section{Article 22. Functions of the Board}

1. Without prejudice to the functions of the Commission under article 21, and without prejudice to the functions of the Board and the Commission under the 1961 Convention, the 1961 Convention as amended and the 1971 Convention:

(a) If, on the basis of its examination of information available to it, to the Secretary-General or to the Commission, or of information communicated by United Nations organs, the Board has reason to believe that the aims of this Convention in matters related to its competence are not being met, the Board may invite a Party or Parties to furnish any relevant information;

(b) With respect to articles 12,13 and 16:

(i) After taking action under subparagraph (a) of this article, the Board, if satisfied that it is necessary to do so, may call upon the Party concerned to adopt such remedial measures as shall seem under the circumstances to be necessary for the execution of the provisions of articles 12, 13 and 16;

(ii) Prior to taking action under (iii) below, the Board shall treat as confidential its communications with the Party concerned under the preceding subparagraphs;

(iii) If the Board finds that the Party concerned has not taken remedial measures which it has been called upon to take under this subparagraph, it may call the attention of the Parties, the Council and the Commission to the matter. Any report published by the Board under this subparagraph shall also contain the views of the Party concerned if the latter so requests.

2. Any Party shall be invited to be represented at a meeting of the Board at which a question of direct interest to it is to be considered under this article.

3. If in any case a decision of the Board which is adopted under this article is not unanimous, the views of the minority shall be stated.

4. Decisions of the Board under this article shall be taken by a twothirds majority of the whole number of the Board.

5. In carrying out its functions pursuant to subparagraph 1 (a) of this article, the Board shall ensure the confidentiality of all information which may come into its possession. 
6. The Board's responsibility under this article shall not apply to the implementation of treaties or agreements entered into between Parties in accordance with the provisions of this Convention.

7. The provisions of this article shall not be applicable to disputes between Parties falling under the provisions of article 32 .

\section{Article 23. Reports of the Board}

1. The Board shall prepare an annual report on its work containing an analysis of the information at its disposal and, in appropriate cases, an account of the explanations, if any, given by or required of Parties, together with any observations and recommendations which the Board desires to make. The Board may make such additional reports as it considers necessary. The reports shall be submitted to the Council through the Commission which may make such comments as it sees fit.

2. The reports of the Board shall be communicated to the Parties and subsequently published by the Secretary-General. The Parties shall permit their unrestricted distribution.

\section{Article 24. Application of stricter measures than those required by this Convention}

A Party may adopt more strict or severe measures than those provided by this Convention if, in its opinion, such measures are desirable or necessary for the prevention or suppression of illicit traffic.

\section{Article 25. Non-derogation from earlier treaty rights and obligations}

The provisions of this Convention shall not derogate from any rights enjoyed or obligations undertaken by Parties to this Convention under the 1961 Convention, the 1961 Convention as amended and the 1971 Convention. 


\section{Article 26. Signature}

This Convention shall be open for signature at the United Nations Office at Vienna, from 20 December 1988 to 28 February 1989, and thereafter at the Headquarters of the United Nations at New York, until 20 December 1989, by:

(a) All States;

(b) Namibia, represented by the United Nations Council for Namibia;

(c) Regional economic integration organizations which have competence in respect of the negotiation, conclusion and application of international agreements in matters covered by this Convention, references under the Convention to Parties, States or national services being applicable to these organizations within the limits of their competence.

Article 27. Ratification, acceptance, approval or act of formal confirmation

1. This Convention is subject to ratification, acceptance or approval by States and by Namibia, represented by the United Nations Council for Namibia, and to acts of formal confirmation by regional economic integration organizations referred to in article 26, subparagraph (c). The instruments of ratification, acceptance or approval and those relating to acts of formal confirmation shall be deposited with the Secretary-General.

2. In their instruments of formal confirmation, regional economic integration organizations shall declare the extent of their competence with respect to the matters governed by this Convention. These organizations shall also inform the Secretary-General of any modification in the extent of their competence with respect to the matters governed by the Convention.

\section{Article 28. Accession}

1. This Convention shall remain open for accession by any State, by Namibia, represented by the United Nations Council for Namibia, and by regional economic integration organizations referred to in article 26, subparagraph (c). Accession shall be effected by the deposit of an instrument of accession with the Secretary-General. 
2. In their instruments of accession, regional economic integration organizations shall declare the extent of their competence with respect to the matters governed by this Convention. These organizations shall also inform the Secretary-General of any modification in the extent of their competence with respect to the matters governed by the Convention.

\section{Article 29. Entry into force}

1. This Convention shall enter into force on the ninetieth day after the date of the deposit with the Secretary-General of the twentieth instrument of ratification, acceptance, approval or accession by States or by Namibia, represented by the Council for Namibia.

2. For each State or for Namibia, represented by the Council for Namibia, ratifying, accepting, approving or acceding to this Convention after the deposit of the twentieth instrument of ratification, acceptance, approval or accession, the Convention shall enter into force on the ninetieth day after the date of the deposit of its instrument of ratification, acceptance, approval or accession.

3. For each regional economic integration organization referred to in article 26, subparagraph (c) depositing an instrument relating to an act of formal confirmation or an instrument of accession, this Convention shall enter into force on the ninetieth day after such deposit, or at the date the Convention enters into force pursuant to paragraph 1 of this article, whichever is later.

\section{Article 30. Denunciation}

1. A Party may denounce this Convention at any time by a written notification addressed to the Secretary-General.

2. Such denunciation shall take effect for the Party concerned one year after the date of receipt of the notification by the Secretary-General. 


\section{Article 31. Amendments}

1. Any Party may propose an amendment to this Convention. The text of any such amendment and the reasons therefor shall be communicated by that Party to the Secretary-General, who shall communicate it to the other Parties and shall ask them whether they accept the proposed amendment. If a proposed amendment so circulated has not been rejected by any Party within twenty-four months after it has been circulated, it shall be deemed to have been accepted and shall enter into force in respect of a Party ninety days after that Party has deposited with the Secretary-General an instrument expressing its consent to be bound by that amendment.

2. If a proposed amendment has been rejected by any Party, the Secretary-General shall consult with the Parties and, if a majority so requests, he shall bring the matter, together with any comments made by the Parties, before the Council which may decide to call a conference in accordance with Article 62, paragraph 4, of the Charter of the United Nations. Any amendment resulting from such a conference shall be embodied in a Protocol of Amendment. Consent to be bound by such a Protocol shall be required to be expressed specifically to the Secretary-General.

\section{Article 32. Settlement of disputes}

1. If there should arise between two or more Parties a dispute relating to the interpretation or application of this Convention, the Parties shall consult together with a view to the settlement of the dispute by negotiation, enquiry, mediation, conciliation, arbitration, recourse to regional bodies, judicial process or other peaceful means of their own choice.

2. Any such dispute which cannot be settled in the manner prescribed in paragraph 1 of this article shall be referred, at the request of any one of the States Parties to the dispute, to the International Court of Justice for decision.

3. If a regional economic integration organization referred to in article 26, subparagraph (c) is a Party to a dispute which cannot be settled in the manner prescribed in paragraph 1 of this article, it may, through a State Member of the United Nations, request the Council to request an advisory opinion of the International Court of Justice in accordance with Article 65 of the Statute of the Court, which opinion shall be regarded as decisive. 
4. Each State, at the time of signature or ratification, acceptance or approval of this Convention or accession thereto, or each regional economic integration organization, at the time of signature or deposit of an act of formal confirmation or accession, may declare that it does not consider itself bound by paragraphs 2 and 3 of this article. The other Parties shall not be bound by paragraphs 2 and 3 with respect to any Party having made such a declaration.

5. Any Party having made a declaration in accordance with paragraph 4 of this article may at any time withdraw the declaration by notification to the Secretary-General.

\section{Article 33. Authentic texts}

The Arabic, Chinese, English, French, Russian and Spanish texts of this Convention are equally authentic.

\section{Article 34. Depositary}

The Secretary-General shall be the depositary of this Convention.

IN WITNESS WHEREOF the undersigned, being duly authorized thereto, have signed this Convention.

DONE AT VIENNA, in one original, this twentieth day of December, one thousand nine hundred and eighty-eight.

Note: The revised list of substances frequently used in the illicit manufacture of narcotic drugs or psychotropic substances included in Tables I and II of the United Nations Convention against Illicit Traffic in Narcotic Drugs and Psychotropic Substances of 1988, is contained in ST/CND/1/ Add.3. 

Vienna International Centre, P.0. Box 500, 1400 Vienna, Austria Tel.: (+43-1) 26060-0, Fax: (+43-1) 26060-5866, www.unodc.org 